\title{
A Review of Hydrothermal Liquefaction of Biomass for Biofuels Production with a Special Focus on the Effect of Process Parameters, Co-Solvents, and Extraction Solvents
}

\author{
Ankit Mathanker ${ }^{1}(\mathbb{D})$, Snehlata Das ${ }^{1}$, Deepak Pudasainee ${ }^{1}{ }^{(\mathbb{D}}$, Monir Khan ${ }^{1}$, Amit Kumar ${ }^{2}$ and Rajender Gupta ${ }^{1, *}$ \\ 1 Department of Chemical and Materials Engineering, University of Alberta, Edmonton, AB T6G 2R3, Canada; \\ mathanke@ualberta.ca (A.M.); snehlata@ualberta.ca (S.D.); pudasain@ualberta.ca (D.P.); \\ mmkhan@ualberta.ca (M.K.) \\ 2 Department of Mechanical Engineering, University of Alberta, Edmonton, AB T6G 2R3, Canada; \\ amit.kumar@ualberta.ca \\ * Correspondence: rajender.gupta@ualberta.ca
}

check for

updates

Citation: Mathanker, A.; Das, S.; Pudasainee, D.; Khan, M.; Kumar, A.; Gupta, R. A Review of Hydrothermal Liquefaction of Biomass for Biofuels Production with a Special Focus on the Effect of Process Parameters, Co-Solvents, and Extraction Solvents. Energies 2021, 14, 4916.

https://doi.org/10.3390/en14164916

Academic Editor: Sergio Ulgiati

Received: 5 July 2021

Accepted: 5 August 2021

Published: 11 August 2021

Publisher's Note: MDPI stays neutral with regard to jurisdictional claims in published maps and institutional affiliations.

Copyright: (C) 2021 by the authors Licensee MDPI, Basel, Switzerland. This article is an open access article distributed under the terms and conditions of the Creative Commons Attribution (CC BY) license (https:// creativecommons.org/licenses/by/ $4.0 /)$.
Abstract: Hydrothermal liquefaction is one of the common thermochemical conversion methods adapted to convert high-water content biomass feedstocks to biofuels and many other valuable industrial chemicals. The hydrothermal process is broadly classified into carbonization, liquefaction, and gasification with hydrothermal liquefaction conducted in the intermediate temperature range of 250-374 ${ }^{\circ} \mathrm{C}$ and pressure of 4-25 MPa. Due to the ease of adaptability, there has been considerable research into the process on using various types of biomass feedstocks. Over the years, various solvents and co-solvents have been used as mediums of conversion, to promote easy decomposition of the lignocellulosic components in biomass. The product separation process, to obtain the final products, typically involves multiple extraction and evaporation steps, which greatly depend on the type of extractive solvents and process parameters. In general, the main aim of the hydrothermal process is to produce a primary product, such as bio-oil, biochar, gases, or industrial chemicals, such as adhesives, benzene, toluene, and xylene. All of the secondary products become part of the side streams. The optimum process parameters are obtained to improve the yield and quality of the primary products. A great deal of the process depends on understanding the underlined reaction chemistry during the process. Therefore, this article reviews the major works conducted in the field of hydrothermal liquefaction in order to understand the mechanism of lignocellulosic conversion, describing the concept of a batch and a continuous process with the most recent state-ofart technologies in the field. Further, the article provides detailed insight into the effects of various process parameters, co-solvents, and extraction solvents, and their effects on the products' yield and quality. It also provides information about possible applications of products obtained through liquefaction. Lastly, it addresses gaps in research and provides suggestions for future studies.

Keywords: biomass; biofuels; bio-oil; bio-crude; char; hydrothermal liquefaction; hydrothermal processing; lignocellulosic biomass

\section{Introduction}

In the recent past, our dependence on technology and energy needs has increased significantly, either in the form of energy consumption for personal use, household purposes, transportation, or agricultural needs. Most of this energy demand is met from fossil fuels such as coal, petroleum, and natural gas. The excessive use of fossil fuels results in increased emissions of oxides of nitrogen, sulfur, mercury, and other trace elements, which are very harmful to human health and vegetation. Apart from these emissions, the use of fossil fuels results in greenhouse gas emissions leading to global warming and drastic climate changes [1]. The depletion of fossil fuels was one of the prominent issues, but now the environment is a much larger concern, forcing researchers to investigate alternative renewable and sustainable sources of energy. 
Energy derived from biomass and biomass waste/residue is attracting a lot of attention. The term biomass refers to all biological matter, i.e., plants, animals, microorganisms, agricultural and forestry residue/waste, marine waste, and municipal and industrial organic waste that is directly or indirectly derived from the process of photosynthesis [2,3]. Biomass is an abundant, cheap, renewable, and environmentally friendly source of energy. Biomass and biomass waste can be used as a fuel, commonly called biofuel, which is produced from organic matter. It is more difficult to handle, store, and transport biomass than to do the same with conventional solid, liquid, and gaseous fossil fuels [4,5]. Biomass is bulky and has low energy density, and a high moisture and low ash content $[4,6]$. Hence, over the years, numerous technologies and methods have been explored to convert biomass into high-density, clean, and easy-to-handle solid, liquid, and gaseous fuels. The first-generation biofuel sources, such as corn, edible oils, and other cereals, are also required to fulfill dietary needs, while the second-generation biofuel sources, such as agricultural and forest residues, wood chips, and pulp/paper remains are available in abundance and can be converted into biofuel. The biofuel from second-generation resources can be produced mainly through biochemical and thermochemical pathways. The thermochemical routes comprise a vast range of technologies, such as combustion, pyrolysis, gasification, and hydrothermal liquefaction (HTL). As biomass contains large amounts of inherent moisture, the thermal treatment-especially combustion, pyrolysis, and gasification of biomass without drying-is problematic and less efficient.

The hydrothermal (HT) process can handle resources with high moisture. HT processing involves the thermochemical conversion of biomass in the presence of a hot and pressurized solvent medium long enough to hydrolyze and degrade the lignocellulosic matter into biofuel [3]. HT processes are broadly classified into three categories depending on temperature and pressure conditions, as shown in Figure 1. The operation that occurs at a temperature range of $180-250{ }^{\circ} \mathrm{C}$ and pressures of $2-10 \mathrm{MPa}$ is called HT carbonization, and the major product obtained is char [7]. The operation that occurs at an intermediate temperature range between 250 and $374{ }^{\circ} \mathrm{C}$ and pressures of 2-25 MPa is HT liquefaction (HTL) and is used to produce high energy-dense liquid fuels, such as bio-oil [8,9]. The major product above critical condition of water $374^{\circ} \mathrm{C}, 22 \mathrm{MPa}$ is gas, the operation in this zone is called HT gasification [10]. In this review, we will limit our discussion to the HTL process. There are few important reasons for limiting the discussion to HTL process. First, the HTL process produces two high quality products hydrochar and bio-oil. The property of hydrochar produced from HTL is very similar to the biochar produced from HTC process, which makes it more advantageous to cover HTL process in this review over HTC. Second, the operation condition for HT gasification is higher when compared to HTL, which makes HT gasification less economic in comparison to HTL. Lastly, HTL is a very broad topic, which involves the study of several parameters for its complete understanding.

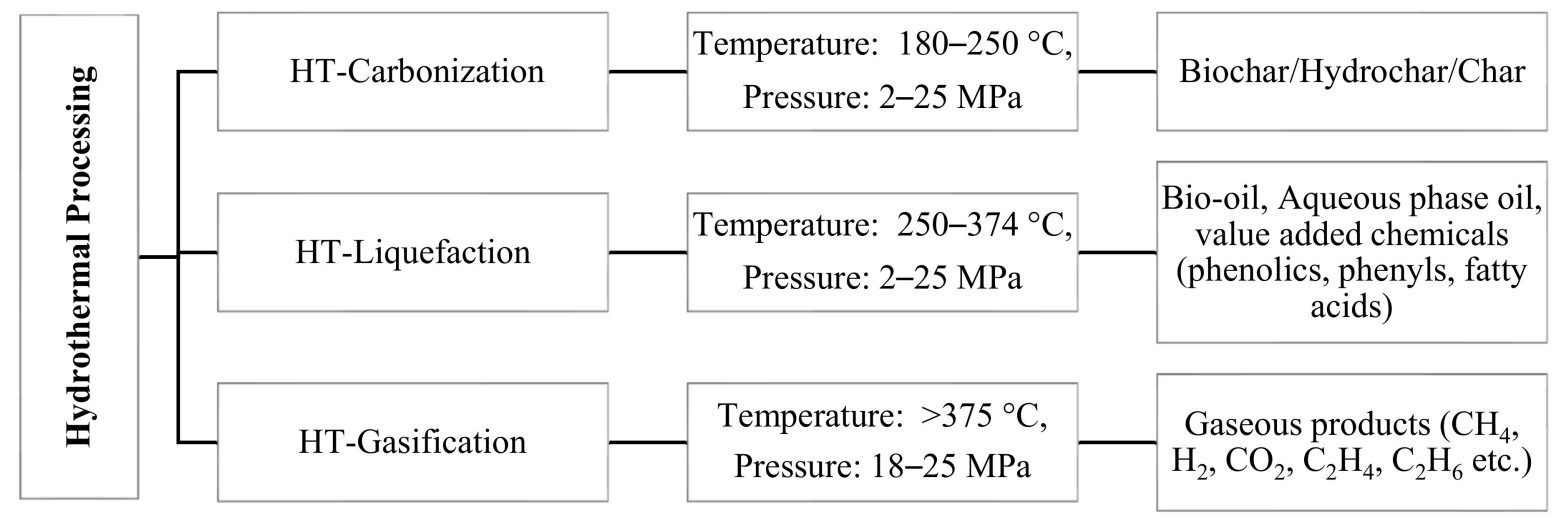

Figure 1. Different hydrothermal processing routes, reaction condition, and products (HT-hydrothermal) $[3,11-18]$. 
This review examines the state-of-the-art HTL process. Section 1 introduces the HTL process, lists the major feedstocks, discusses about the HTL reaction mechanism, and details about the type (batch and continuous), and scale (laboratory, bench, and pilot) of HTL operations, followed by extraction procedures and calculation methods. Section 2 provides a detailed discussion about the effect of various process parameters, primarily from the point of view of optimizing bio-oil yield. The role of various catalysts and solvents in the HTL process and their effects on the product yield and quality are discussed in Section 3. Section 4 summarizes various HTL products, their characteristics, and applications. Sections 5 and 6 provide concluding remarks, address research gaps, and suggest topics for future study.

\subsection{Hydrothermal Liquefaction}

HTL is also known as hydrothermal treatment or hydrothermal upgrading. As shown in Figure 1, the optimum range of HTL operations is in the temperature range of $250-374{ }^{\circ} \mathrm{C}$ with a final pressure of 2-25 MPa. In general, water is used as a process medium. Using water as a medium benefits the hydrolysis reaction that occurs in HTL. Removing moisture can be a costly pre-treatment step in techniques like combustion, pyrolysis, and gasification. However, as there is no need to pre-treat biomass to remove moisture, HTL is considered a more economical alternative for bio-oil production. HTL has been used for a long time. A recent review by Gollakota et al. [19] provides a detailed history of the evolution of HTL.

\subsection{Major Lignocellulosic Biomass Feedstocks and HTL Mechanism}

Agricultural and forest residue are two main sources of lignocellulosic biomass. The name lignocellulosic mainly describes the key structural components-lignin, cellulose, and hemicellulose-present in agricultural and forest biomass. The elemental composition mainly consists of carbon, hydrogen, and oxygen with traces of nitrogen, sulfur, and mineral impurity. Some major feedstocks along with their structural and elemental compositions are described in Table 1.

Cellulose is a homo-polysaccharide formed by the linearly coupled D-glucopyranoside units connected by $\beta$-glycosidic linkages in a 1:4 fashion [20]. Increased packing density in cellulose structure leads to the formation of crystalline structures, which are insoluble in an aqueous medium under normal conditions and require rigorous treatment for hydrolysis and degradation, whereas the non-crystalline structure is easily hydrolyzed [21,22]. Hemicellulose is mainly composed of D-glucose, D-xylose D-mannose, and D-galactose along with some other glycosyls. It has a poor structural formation leading to a reduced crystallinity, making it more susceptible to water [2]. Lignin is a three-dimensional structure made of ether bonds and $\mathrm{C}-\mathrm{C}$ linkages. The three main monomeric units of lignin are p-coumaryl alcohol, coniferyl alcohol, and sinapyl alcohol [14].

Table 1. Chemical and elemental composition of major feedstock and bio-oil yield.

\begin{tabular}{|c|c|c|c|c|c|c|c|c|c|c|}
\hline Feedstock & Cellulose & Hemicellulose & Lignin & Carbon & Hydrogen & Oxygen & $\mathrm{H} / \mathrm{C}$ & $\mathrm{O} / \mathrm{C}$ & Bio-Oil & Ref. \\
\hline \multicolumn{11}{|c|}{ Agricultural Feedstock } \\
\hline Corn straw & 30.81 & 25.52 & 16.76 & 44.57 & 5.53 & 33.70 & 1.49 & 0.57 & 7.9 & [23] \\
\hline Peanut straw & 36.56 & 20.27 & 18.36 & 41.42 & 5.51 & 35.21 & 1.60 & 0.64 & 14.6 & [23] \\
\hline Rice straw & 46.33 & 31.09 & 10.17 & 41.34 & 5.33 & 34.29 & 1.55 & 0.62 & 15 & [23] \\
\hline Soybean straw & 42.39 & 22.05 & 18.93 & 45.99 & 6.07 & 39.00 & 1.58 & 0.64 & 15.8 & [23] \\
\hline Corn stover & 45.00 & 30.00 & 16.00 & 43.57 & 5.84 & 49.98 & 1.61 & 0.86 & 27.15 & {$[24,25]$} \\
\hline Rice straw & 42.87 & 25.15 & 31.97 & 38.55 & 5.50 & 55.34 & 1.71 & 1.08 & 27.6 & [26] \\
\hline Barley straw & 46.00 & 23.00 & 15.00 & 44.66 & 6.34 & 47.97 & 1.70 & 0.81 & 34.9 & [27] \\
\hline Castor residue & 38.42 & 22.40 & 20.20 & 43.59 & 5.56 & 46.16 & 1.53 & 0.79 & 15.8 & [28] \\
\hline Pre-treated sorghum bagasse & 49.84 & 8.01 & 24.65 & 43.20 & 5.80 & 41.40 & 1.61 & 0.72 & 23.42 & [29] \\
\hline
\end{tabular}


Table 1. Cont.

\begin{tabular}{|c|c|c|c|c|c|c|c|c|c|c|}
\hline Feedstock & Cellulose & Hemicellulose & Lignin & Carbon & Hydrogen & Oxygen & $\mathrm{H} / \mathrm{C}$ & $\mathrm{O} / \mathrm{C}$ & Bio-Oil & Ref. \\
\hline \multicolumn{11}{|c|}{ Forest Feedstock } \\
\hline Oakwood & 38.10 & 23.00 & 32.00 & 50.20 & 7.00 & 42.80 & 1.67 & 0.64 & 23.17 & {$[30,31]$} \\
\hline Palm kernel shell & 24.50 & 22.90 & 33.50 & 47.77 & 4.06 & 47.55 & 1.02 & 0.75 & 24 & {$[32]$} \\
\hline Empty fruit bunch & 26.60 & 26.90 & 18.60 & 43.62 & 4.03 & 50.22 & 1.11 & 0.86 & 16 & [32] \\
\hline Palm mesocarp fiber & 23.10 & 22.20 & 30.60 & 46.29 & 4.67 & 47.37 & 1.21 & 0.77 & 16 & [32] \\
\hline Poplar wood & 52.16 & 18.92 & 22.97 & 47.04 & 5.60 & 43.20 & 1.43 & 0.69 & 28.49 & [33] \\
\hline Birch sawdust & 45.30 & 24.20 & 22.90 & 48.50 & 6.30 & 45.20 & 1.56 & 0.70 & 22.3 & [34] \\
\hline Aspen wood & 47.14 & 19.64 & 22.11 & 50.39 & 6.19 & 43.23 & 1.47 & 0.64 & 20.65 & [35] \\
\hline Datura stramonium L. stem & 42.20 & 23.13 & 24.33 & 43.55 & 5.98 & 49.70 & 1.65 & 0.86 & 32 & [36] \\
\hline Poplar wood & 44.95 & 34.05 & 25.85 & 46.72 & 6.18 & 46.96 & 1.59 & 0.75 & 17.5 & [37] \\
\hline Furniture sawdust & 32.63 & 37.23 & 22.16 & 47.42 & 5.67 & 46.71 & 1.43 & 0.74 & 12.1 & [38] \\
\hline Cypress & 46.30 & 27.60 & 28.80 & 48.90 & 6.00 & 44.80 & 1.47 & 0.69 & 27.5 & [39] \\
\hline Pine & 39.54 & 20.61 & 30.15 & 49.52 & 6.49 & 43.89 & 1.57 & 0.66 & 24.2 & [40] \\
\hline Paulownia & 42.35 & 25.22 & 23.44 & 45.50 & 6.30 & 48.20 & 1.66 & 0.79 & 27.01 & [41] \\
\hline Oil palm shell & 39.70 & 21.80 & 32.50 & 50.01 & 7.66 & 29.02 & 1.84 & 0.44 & 18.5 & [42] \\
\hline Beech wood & 45.05 & 31.50 & 22.25 & 44.68 & 6.08 & 49.24 & 1.63 & 0.83 & 22 & [43] \\
\hline Scotch pine & 47.30 & 20.54 & 27.70 & 48.33 & 6.49 & 45.18 & 1.61 & 0.70 & 24.6 & [44] \\
\hline
\end{tabular}

\subsubsection{Cellulose Decomposition}

In the hydrothermal process, cellulose reacts with water at an elevated temperature, which breaks the hydrogen bond in the cellulose, weakening its crystallinity. Cellulose is hydrolyzed into glucose, fructose, and other monomeric units, which is followed by further degradation of these units in simpler hydrocarbons. The pathway of cellulosic hydrolysis and $\mathrm{C}-\mathrm{O}-\mathrm{C}$ bond cleavage can be different according to the acid, the base, and the neutral medium, as shown in Figure 2a [45]. For instance, acid hydrolysis takes place by the reaction of the acidic proton and oxygen that bonds two glucose units and forms the conjugated acid, which, on the cleavage of glycosidic bonds, forms two glucose units [46]. In basic medium, the breaking of the $\mathrm{C}-\mathrm{O}-\mathrm{C}$ bond occurs when the $\mathrm{OH}^{-}$attacks at the anomeric carbon, whereas in the presence of water, the glycosidic unit and water split at the same time and form two glucose units [47].

Hirano et al. [48] presented the plausible mechanism for cellulose hydrolysis and inferred that the major monomeric units formed are glucose and fructose, which, on condensation and isomerization, produce unstable intermediates, such as erythrose, glycolaldehyde, dihydroxyacetone, and its reversible isomer, glyceraldehyde. Erythrose on hydrogenation produces erythritol. The intermediate erythritol and glyceraldehyde further dehydrate to form 2,3-butanedione and pyruvaldehyde, respectively. Some major intermediate reaction that occurs during HTL of cellulose is shown in Figure 2b. In the presence of catalysts that promote hydrogenation, these intermediates result in the formation of stable $\mathrm{C}_{2}-\mathrm{C}_{3}$ alcohols, such as 3-hydroxy-2-butanone, hydroxy acetone, 2,3-butanediol, propylene glycol, and ethylene glycol.

Li et al. [49] found the final composition from cellulose HTL to be a mixture of esters, aldehydes, ketones, and a small fraction of alcohol, and ether. Esters, being the most abundant, were devised to be formed via an $\alpha$-hydrogen donation to intermediates, resulting in the formation of majorly 2-hydroxy-acetic acid ethyl ester, 2-hydroxy propanoic acid ethyl ester, and 4-oxo-pentanoic acid ethyl ester. The aldehyde and ketones formed because of a series of decomposition, dehydration, isomerization, and aldol reactions. Gao et al. [50] investigated the effect of temperature on cellulose decomposition and found that at $200{ }^{\circ} \mathrm{C}, 50 \%$ of the products were 5-HMF (5-hydroxy methyl-2-furancarboxaldehyde), $10 \%$ were ketones (major: 4-hydroxy-4-methyl-2-pentanon), and $5 \%$ were acids, such as acetic acid, levulinic acid, and n-hexadecanoic acid. At higher temperatures of $300-400{ }^{\circ} \mathrm{C}$, products were more distributed in a class of acids, aldehydes, ketones, furans, esters, phenols, phenyl, and nitrogenous compounds. 


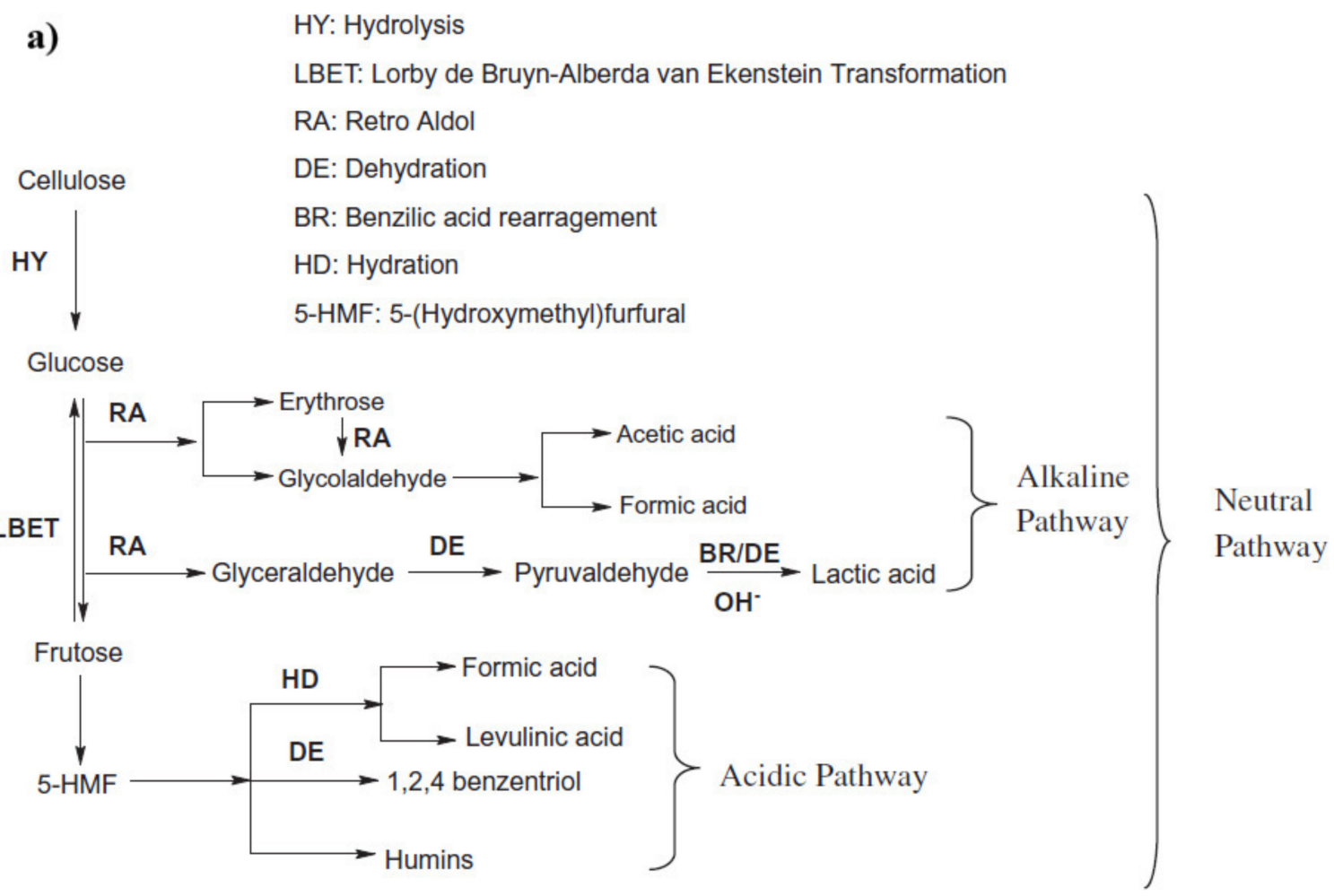

b)

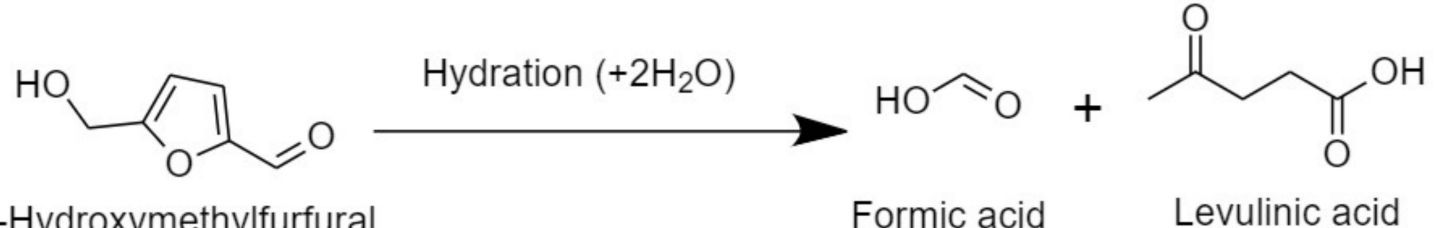

5-Hydroxymethylfurfural

Formic acid

Levulinic acid<smiles>CCCCCCCCCCCCO</smiles>

5-Hydroxymethylfurfural<smiles>Oc1ccc(O)c(O)c1</smiles>

1,2,4 Benzentriol<smiles>O=C[C@@H](O)[C@@H](O)CO</smiles>

D-Erythrose

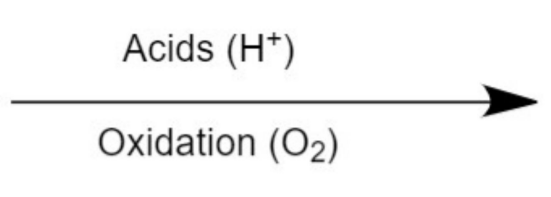

Acetic acid Formic acid

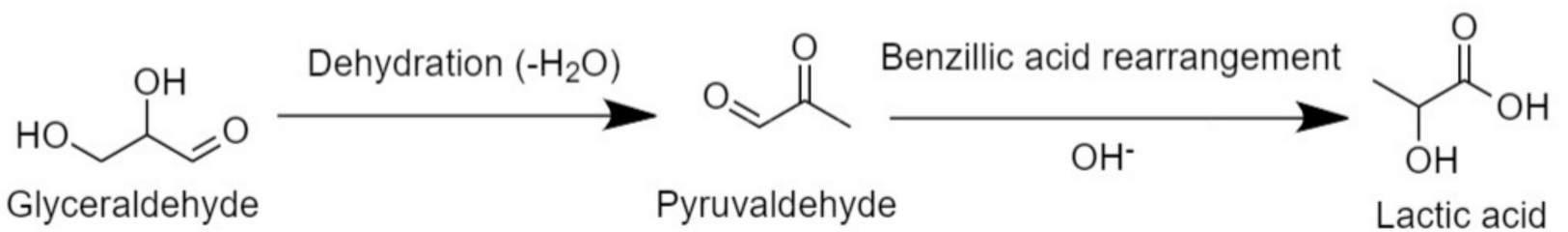

Figure 2. (a) Proposed routes of HTL of cellulose (adapted Sudong et al. [45]), copyright from Elsevier 2012, (b) major intermediate reactions during HTL of cellulose. 
In order to understand the degradation characteristics of empty fruit bunch, Miyata et al. [51] studied the effect of model substrates (cellulose, xylan, glucose, xylose, dihydroxyacetone, pyruvaldehyde, and hydroxyacetone) in enhancing the yield of water-soluble (WS) product. Later, through catalytic cracking the WS product was converted to bio-oil. It was found that non-catalytic HTL of cellulose, xylan, glucose, and xylose yielded $58 \mathrm{wt} \%$, $64 \mathrm{wt} \%, 53 \mathrm{wt} \%$, and $64 \mathrm{wt} \%$ of WS, respectively. In case of Fe-assisted HTL, the production of WS from cellulose increased to $93 \mathrm{wt} \%$, glucose to $74 \mathrm{wt} \%$, and xylan and xylose both to $80 \mathrm{wt} \%$. It can be said that cellulose can significantly enhance the production of bio-oil in the presence of metal catalysts.

The yield of bio-oil significantly depends on the biochemical composition of biomass. The weight percentage of cellulose content and the ratio of $\mathrm{w}_{\text {cellulose }} / \mathrm{w}_{\text {hemicellulose }}$ in biomass are two important factors affecting the yield. Figure 3a shows the plots of different studies involving agricultural feedstock with varied composition. These studies showed that cellulose content plays a dominant role in deciding the yield of bio-oil in the case of agricultural feedstock. The plotted analysis of results from previous studies on different forest-based feedstocks as shown in Figure $3 \mathrm{~b}$ it was observed that the $\mathrm{w}_{\text {cellulose }} / \mathrm{w}_{\text {hemicellulose }}$ ratio was dominant over the cellulose content in determining the bio-oil yield for forest feedstock.

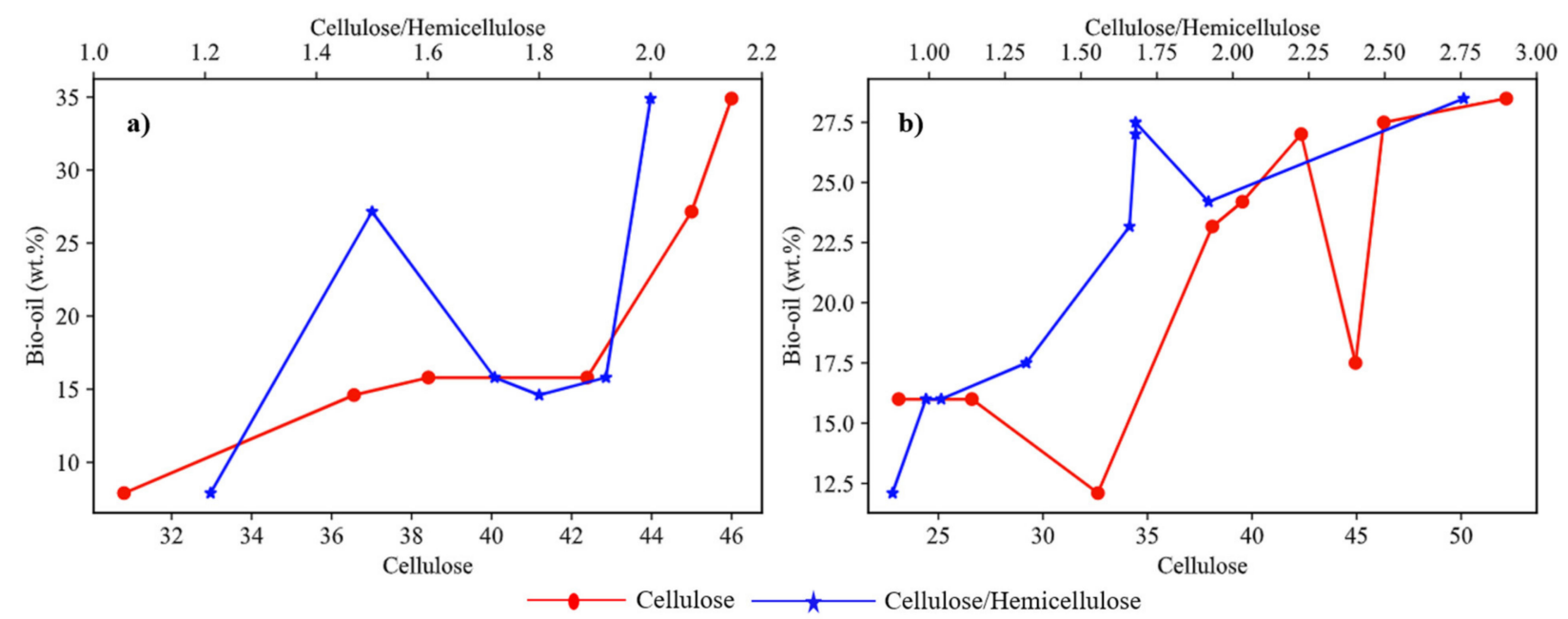

Figure 3. Effect of cellulose and cellulose/hemicellulose ratio on bio-oil yield for (a) agricultural feedstocks [23-28], (b) forest feedstock $[26,27,29,32,33,35,38,40,41]$.

\subsubsection{Lignin Decomposition}

The ether bond connecting three basic phenylpropane units in lignin has a low bond dissociation energy and the macromolecular unit is hydrolyzed in the presence of sub- and supercritical water, forming the basic units of p-coumaryl alcohol, coniferyl alcohol, and sinapyl alcohol. The basic units undergo further dissociation by hydrolysis of the side C-C bonds to form aromatics [52]. The primary components obtained during softwood lignin decomposition are guaiacols, catechols, and alkylphenols. Guaiacols, catechols, and alkylphenols are mostly formed via hydrolysis and the breaking of ether and C-C bonds. In a high temperature HTL environment, catechols and alkylphenols are also formed through the demethoxylation of guaiacols and the alkylation of hydroxylated benzene, respectively [52,53]. The formation of cresols, ethyl phenols, and methyl benzenediols takes place through the alkylation of respective phenols and benzenediols as shown in Figure 4 [54,55]. Nguyen et al. [56] performed a temperature study on the product composition of lignin liquefaction and found that the fraction of guaiacols and phenolics dimers decreased significantly when the temperature in the sub-critical zone increased at the same time that the fraction of alkylphenols, anisoles, and catechols increased. In summary, cellulose and hemicellulose mainly contribute to the formation of acids, esters, fatty acid alkyl esters, 
ketones, aldehydes, furans, alcohols, and ether, whereas lignin mostly dissociates to form aromatic compounds.

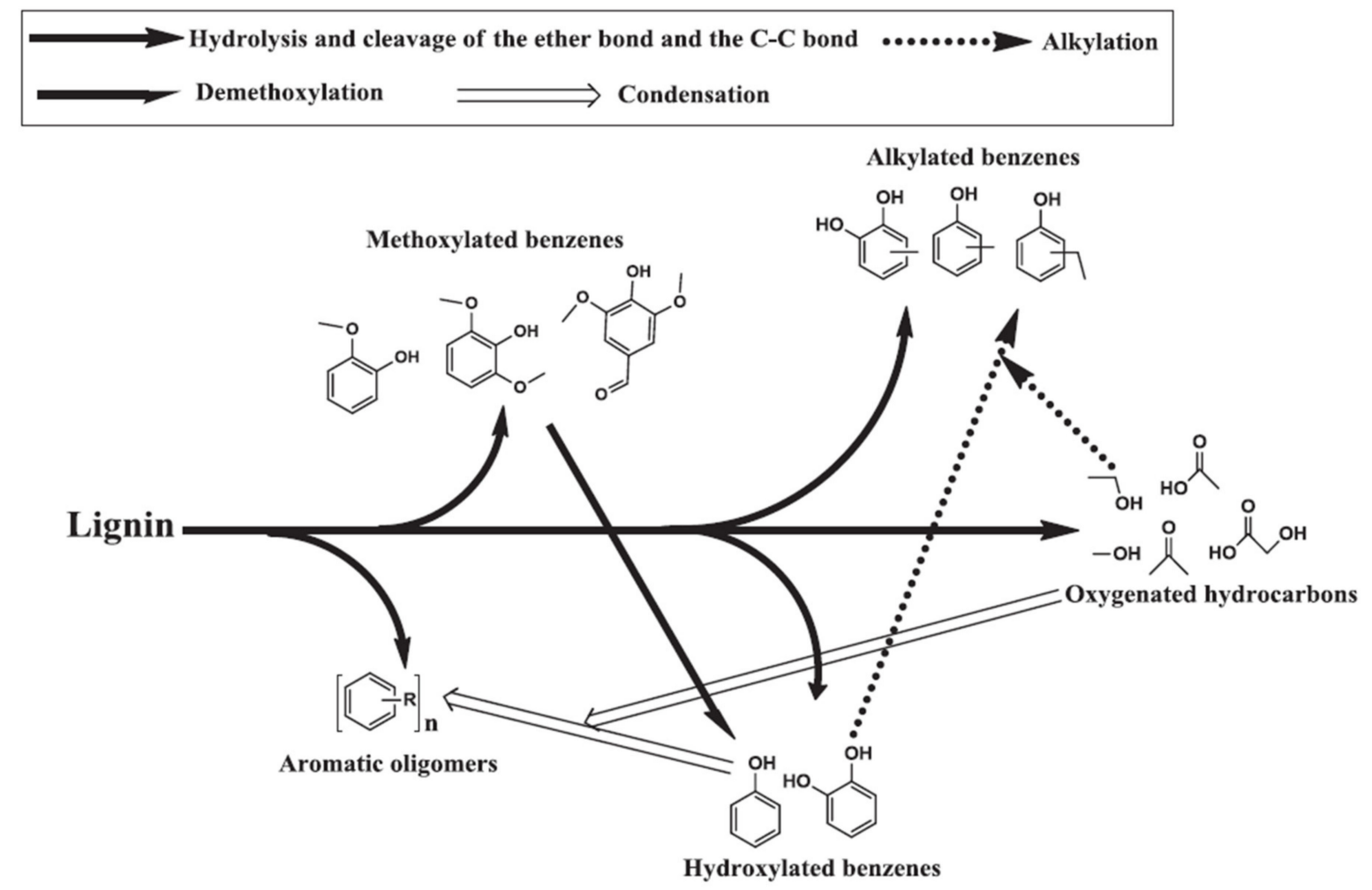

Figure 4. Proposed pathway for hydrothermal lignin decomposition [55], copyright Elsevier 2013.

\subsection{Hydrothermal Liquefaction Process}

\subsubsection{Batch Process}

Most HTL experiments have been studied in a batch reactor at a laboratory scale, though there has been a significant improvement in pilot scale studies in a continuous system over the last 10 years. In general, the batch reactor studies have been carried out in a cylindrical autoclave reactor made of either stainless steel, Hastelloy C-22, or Inconel-625 with a typical size of 100-1000 mL. Some studies used a tubular reactor $(25 \mathrm{~mL})$ made of stainless steel, whereas a self-assembled Swagelok port connector and caps also serve as a batch reactor [57]. The typical assembly of a batch reactor consists of a stirrer, inlet and outlet tubes, valves for gas pressurization and depressurization, a heating and cooling system, temperature detector, pressure gauge, and controller. The heating system can be either an external electric furnace, coil heating, or sand bath heating. The cooling system can be an electric fan or chilled water with tubular coil. Other than that, the reactor is connected to a gas cylinder to provide an initial pressure (inert gas) to prevent a phase change during the process. It also contains a temperature detector. Once the reactor is loaded with feedstock and solvent, it is purged with an inert gas and pressurized with either an inert gas or a process gas. One common challenge faced with conventional batch reactor is the long time it takes to reach the final process temperature and similarly long time required for its cooling, which notably increases the overall time spend by products at a relatively high subcritical temperature regime. The problem with the long heating time is the side reactions associated with it, which decreases the total oil yield. Brand et al. [58] discussed the effect of heating rate on bio-oil yield and found that a combination of fast heating rate, high temperature, and immediate quenching can highly improve the yield of bio-oil. Another problem associated with the batch reactor is the improper mixing of biomass-water slurry, which leads to formation of dead zones at bottom corners. The 
biomass accumulates in the dead zones, giving rise to incomplete conversion and formation of char.

\subsubsection{Continuous Process}

In the batch process, the reactor takes a long time to reach the final temperature; the long heating time to reach subcritical temperature promotes enhanced degradation. However, the process with the final temperature as the critical condition of water, the heating time is significantly longer; this long heating time promotes a side reaction, resulting in intermediate formation, repolymerization, and cracking. One objective of moving from a batch to a continuous system is to achieve a fast-heating rate at high temperature. The heating time in the continuous system is adequate to support easy hydrolysis and decomposition of biomass while eliminating side reactions, which happens during a long heating time. Converting higher amounts of biomass in a small processing unit requires a highpressure feeding system for concentrated biomass slurries, which is another technological challenge in process development [10].

Limited research has been conducted in the field of a large-scale continuous HTL process for bio-oil production using lignocellulosic biomass. Toor et al. [59] studied the catalytic liquid conversion of wet distillers' grain with solubles (WDGS) in a $30 \mathrm{dm}^{3} \mathrm{~h}^{-1}$ continuous pilot plant at a subcritical temperature of $350{ }^{\circ} \mathrm{C}$ and a pressure of $25 \mathrm{MPa}$ with the feed flow maintained at $11 \mathrm{dm}^{3} \mathrm{~h}^{-1}$. A high-pressure feed pump and recirculation pump were used to maintain a high flow rate. In order to heat the feed mixture quickly, the recirculating pump was designed to supply nine parts of pre-heated feed to mix with one part of new feed, which then reached the operative temperature with a small addition of heat through a trim heater. Mørup et al. [60] developed a batch autoclave assembly, which he called a stop-flow reactor system. It had a capacity of $170 \mathrm{~mL}$ with inlets and outlets allowing injection of feed and ejection of the product one at a time at elevated temperatures. The system also had a high-pressure to maintain the temporary flow mode in reactor. The reactor supported fast heating and performed multiple identical runs in a sequence without needing to be cooled. High-pressure pneumatic pumps were used to inject and eject materials.

Anastasakis et al. [61] used an Aarhus University pilot-scale HTL reactor for liquefaction of miscanthus, spirulina, and sewage sludge. The HTL system was a $140 \mathrm{~m}$ long tubular set-up of a constant cross section $(14.2 \mathrm{~mm})$ with a total system volume of $20 \mathrm{~L}$. The feeding system consisted of a progressive cavity pump for continuous recirculation slurry in a hopper. To support an efficient flow rate, a positive displacement pump with a flowrate capacity of $600 \mathrm{~L} \mathrm{~h}^{-1}$ and delivery pressure capacity of 476 bar was used to deliver feed at a flow rate of $60 \mathrm{~L} \mathrm{~h}^{-1}$ at a pressure of approximately $220 \mathrm{bar}$. A doublepipe counter-current heat exchanger was used for initial heating of slurry with a K-type thermocouple. After the heat exchangers, the slurry passed through the trim heater, which consisted of 32 independent electric heaters (heating capacity $1 \mathrm{~kW}$ each) to increase the temperature of the slurry to match the reaction temperature. The reactor assembly was a 10-pipe system with five convolutions. It was surrounded by heating tapes with $1 \mathrm{~kW}$ of power. To prevent heat loss, the hot zones were heavily insulated with stainless steel casing. To increase the turbulence in the system for better mixing and heat exchange, a novel two-piston $(0.5 \mathrm{~L})$ hydraulic oscillation system was used, and a similar hydraulic system was used at product take-off. The product collection zone consisted of a hydro cyclone to separate the liquid and gaseous stream, and a separating funnel to separate the different phase liquid products.

There are a few more big projects focused on scaling HTL operations to understand large-scale process parameters and operational technicality and economics. Elliott et al. [10] published a detailed review of continuous systems and explored HTL pathways at intermediate conditions to produce bio-crude, understand energy balance, and cost analysis. Castello et al. [62] examined state-of-the-art continuous HTL process with data interpretation from existing literature. Tran et al. [63] proposed a conceptual model for a tubular 
plug flow system, focusing on the key objective of making an efficient HTL continuous system. The major objectives were achieving prompt, strong, and uniform mixing for proper heating and conversion, short residence time to avoid char formation, rapid heating of slurry in a reactor to prevent side reactions, and speedy downstream flow of products out of the reactor to avoid accumulation.

Tran et al. [63] pointed out some of the main problems faced during a continuous plug-flow operation. The formation of char from incomplete conversion of biomass and that of coke from decomposition of bio-oil leads to clogging of the reactor over several hours of operation. Use of a catalyst can limit the formation of side products, though the cost of catalysts and the challenges to recover catalysts increases the total cost of the process. The limited availability of data and tests conducted on a high-pressure feeding system of high concentration slurries makes it difficult to estimate the economic cost of large-scale operation. Thus, a high-pressure feeding system for biomass slurries remains a technological challenge in development of HTL process [10].

\subsubsection{Extraction Methods and Product Calculations}

The HTL experiment consists of two main steps: the reaction process and the extractive product separation. The first part of the experiment includes loading feedstocks in the reactor, followed by the reactor heated to its final temperature and then being cooled until it comes back to room temperature. The next step includes separating various product fractions: bio-oil, aqueous phase, char, and gas. There are several methods of product separation with some differences in the liquid phase separation step. Once the reactor reaches room temperature, it is depressurized, all the gaseous products are collected in a Tedlar bag, and the composition is analyzed with gas chromatography (GC) equipped with either a thermal conductivity detector (TCD) or flame ionization detector (FID). The reactor is opened, and the product mixture is filtered using filtration and filter paper to separate the solid fraction from the aqueous medium. The solid residue stuck to the reactor's bottom, sides, and stirrer is recovered using an extractive solvent, such as acetone [64-66]. The solid fraction is washed a few times with acetone to recover all of the organic phase from its pores. It is mixed with acetone recovered from the reactor. The acetone-phase mixture is treated in a rotary evaporator to remove the acetone or else the acetone phase is centrifuged at a high speed to separate out the acetone. The collected product is dark brown. This highly viscous phase is commonly referred to as heavy oil or bio-crude. A solid residue, it is dried at room temperature or in an oven before undergoing elemental analysis to understand its composition, Fourier transformation infrared spectroscopy (FTIR), to study the presence of functional groups on its surface, and a morphology study. The aqueous medium consists of a water-soluble organic phase and inorganic phase based on the type and composition of feedstock and the catalyst used. Instead of acetone, many other extractive solvents, such as tetrahydrofuran (THF) [67], toluene [32], dichloromethane (DCM), methyl tert-butyl ether (MTBE) [68], ethyl acetate (EAC), isopropyl alcohol (IPA), and hexane [69] have been tested.

In general, the water is evaporated from the aqueous medium and the product is referred to as aqueous phase oil. Karagoz et al. [70] focused on the detailed extraction of different oil phases from an aqueous medium using a liquid-liquid extraction method. For this, aqueous organics were first extracted using diethyl ether (DEE) and the remaining water phase was again extracted with EAC. Both solvents were evaporated to obtain different oil fractions along with oil obtained from the acetone phase during the solid wash.

In a similar extractive procedure with different extractive solvents, Wang et al. [71] used benzene, hexane, and THF to obtain a bio-oil fraction, asphaltene fraction, and pre asphaltene fraction.

The various oil fractions are characterized for both physical properties and chemical compositions. The most common tests performed to understand the physical properties of oil are a viscosity measurement, total acid number analysis, water content analysis, and iodine value analysis. Similarly, the chemical composition is obtained from CHNS and gas chromatography and mass spectroscopy (GCMS) analysis. 
The product yield is calculated based on the way different products are collected. Some of the calculations can be generalized as shown below:

$$
\begin{gathered}
\text { Total conversion }(w t . \%)=\frac{\text { Weight of feedstock }- \text { Weight of solid residue }}{\text { Weight of feedstock }} \times 100 \\
\text { Weight of solid residue }(w t . \%)=\frac{\text { Weight of solid residue }}{\text { Weight of feedstock }} \times 100 \\
\text { Weight of heavy oil }(w t . \%)=\frac{\text { Weight of heavy oil }}{\text { Weight of feedstock }} \times 100 \\
\text { Weight of other oil phase }(w t . \%)=\frac{\text { Weight of oil phase }}{\text { Weight of feedstock }} \times 100
\end{gathered}
$$

In cases where the weight of the gaseous product is measured, its percentage is simply calculated as $[23,72]$ :

$$
\text { Weight of gas }(w t . \%)=\frac{\text { Weight of gaseous product }}{\text { Weight of feedstock }} \times 100
$$

In cases where it is not practical to record the weight of the gas phase, its weight fraction is calculated using the difference between reactor loading and recovered mixture weight:

$$
\text { Weight ofgas }(w t . \%)=\frac{\text { Weight loaded }(\text { feedstock }+ \text { solvent })-\text { Weight recovered from reactor }}{\text { Weight recovered from reactor }} \times 100
$$

\begin{tabular}{|c|c|c|c|c|}
\hline S. No & Year & Description/Objective & Results/Observations/Major Findings & Ref. \\
\hline 1 & 2011 & $\begin{array}{l}\text { HTT of microalgae: evaluation of the } \\
\text { process as conversion method in an algae } \\
\text { biorefinery concept. } \\
\text { To understand the effect of wide range of } \\
\text { condition }\left(175-450^{\circ} \mathrm{C} \text {, up to } 60 \mathrm{~min}\right) \text { to } \\
\text { obtain the optimum range. }\end{array}$ & $\begin{array}{l}\text { The maximum bio-oil yield ( } 49 \mathrm{wt} \%) \text { was obtained at } \\
375{ }^{\circ} \mathrm{C}, 5 \mathrm{~min} \text {. Up to } 75 \% \text { of the calorific value of algal } \\
\text { biomass can be retrieved in oil phase. } \\
\text { With high oil yield, its pronounced increase in nitrogen } \\
\text { content was observed }(6 \mathrm{wt} \%) \text {. } \\
\text { The dissolved inorganic } \mathrm{N} \text { and } \mathrm{P} \text { content in the aqueous } \\
\text { phase points at recycling of the nutrients for next } \\
\text { generation algal growth. }\end{array}$ & [73] \\
\hline 2 & 2011 & $\begin{array}{l}\text { Effect of operating conditions of } \\
\text { thermochemical liquefaction on bio-crude } \\
\text { production from Spirulina platensis. }\end{array}$ & $\begin{array}{l}\text { Bio-crude obtained in the study has properties in range } \\
\text { with the petroleum crude and could be further refined to } \\
\text { obtain transportation fuel. } \\
\text { Carbon conversion efficiency of } 98.3 \% \text { was obtained at } \\
350{ }^{\circ} \mathrm{C}, 60 \mathrm{~min} \text {, and } 20 \% \text { solid concentration. }\end{array}$ & [74] \\
\hline 3 & 2011 & $\begin{array}{l}\text { Bio-crude production from secondary } \\
\text { pulp/paper mill sludge and waste } \\
\text { newspaper via co-liquefaction in } \\
\text { hot-compressed water. } \\
\text { Investigate the effect of temperature and } \\
\text { selected catalyst (HCOOH, } \mathrm{KOH} \text {, and FeS) } \\
\text { on product yield. }\end{array}$ & $\begin{array}{l}\text { Addition of catalyst at } 300{ }^{\circ} \mathrm{C} \text { was found to increase the } \\
\text { yield of heavy oil. } \\
\text { Synergistic effect was observed on the yield of bio-oil } \\
\text { when secondary pulp/paper mill sludge and newspaper } \\
\text { waste was used. }\end{array}$ & [75] \\
\hline
\end{tabular}

\section{Effect of Process Parameters}

The effect of various process parameters such as temperature, pressure, retention time, heating rate, and biomass-to-solvent ratio is discussed in this section. Table 2. briefly summarizes the outcomes on some major studies focusing on the effect of process parameters.

Table 2. Some major studies on the effects of temperature, pressure, retention time, feed ratio, and heating rate. 
Table 2. Cont

\begin{tabular}{ccc}
\hline S. No & Year & Description/Objective \\
\hline 4 & 2012 & $\begin{array}{c}\text { To understand the effects of different } \\
\text { reaction conditions on HTT of cornelian } \\
\text { cherry stones and bio-oil composition. }\end{array}$
\end{tabular}

Characterization of products from HTL of cellulose. on HTL process.
52012 Effect of temperature and residence time

Results/Observations/Major Findings

Ref.

It was observed that at a temperature of $200{ }^{\circ} \mathrm{C}$, longer retention time of $30 \mathrm{~min}$ gave higher yield, whereas at $250{ }^{\circ} \mathrm{C}$ and $300{ }^{\circ} \mathrm{C}$, shorter retention time of 0 min was more effective.

The major compound observed in heavy bio-oil was linoleic acid at both 250 and $300^{\circ} \mathrm{C}$.

Longer retention time did not facilitate increased production of oil.

The residual char had core-shell structure, the core contained ketone and ether groups and the shell contained carboxylic and carbonyl groups.

HTL of Litsea cubeba seed to produce bio-oils.

62013 Effect of temperature, residence time, reactor loading, and catalyst concentration was studied to maximize production.

In this study, $\mathrm{Na}_{2} \mathrm{CO}_{3}$ suppressed the polymerization pathways and, hence, negatively impacted the yield of bio-oil, which is contradictory to other studies.

The bio-oil yield increased with increase in reactor loading up to a certain extent.

In case of subcritical water, no significant effect of heating rate was observed for lower temperature of 250-280 ${ }^{\circ} \mathrm{C}$, whereas significant change in conversion and bio-crude was observed for temperature above $315^{\circ} \mathrm{C}$.

Effect of heating rate on biomass subcritical water and supercritical ethanol.

Only a marginal effect of supercritical ethanol as solvent was observed on HTL conversion and bio-crude yield.

Alkaline pretreatment disrupts surface barriers and increases surface availability of biomass.

Alkaline pretreatment helps to suppress the re-polymerization reactions during HTL. It markedly enhanced the bio-oil yield at optimum temperature.

Alkaline pretreatment and HTL of cypress for high yield bio-oil production. Understand the reaction mechanism.
The effect of temperature on the catalytic conversion of Kraft lignin using near critical water.

The catalytic conversion was studied $9 \quad 2014$ using $\mathrm{ZrO}_{2} / \mathrm{K}_{2} \mathrm{CO}_{3}$ catalyst and phenol as co-solvent and char suppressing agent. The reaction temperature studied were 290-370 ${ }^{\circ} \mathrm{C}$ in a continuous flow reactor with feed flow of $1 \mathrm{~kg} \mathrm{~h}^{-1}$.

Bio-oil production from oil palm biomass (empty fruit bunch, palm mesocarp fiber, and palm kernel shell) via subcritical and supercritical HTL.

HTL of rice straw: effect of reaction environment.

112015

Effect of $\mathrm{N}_{2}, \mathrm{O}_{2}$, and $\mathrm{CO}_{2}$ on product distribution.
As the temperature increased the yield of water-soluble organics increased (5-11 wt \%), bio-oil decreased (87-69 wt\%) and that of char increased (16-22 wt\%). The yield of catechols, alkylphenols, and anisoles increased with increase in temperature whereas the mass fraction of guaiacols and phenol dimers decreased.

Total mass fraction of phenol-free compounds increased with increase in temperature in both water-soluble fraction and lignin bio-oil.

The optimum condition for HTL of all oil palm biomass was $390^{\circ} \mathrm{C}$ and $25 \mathrm{MPa}$ with bio-oil yield of palm kernel shell $(38.5 \mathrm{wt} \%)>$ empty fruit bunch $(37.4 \mathrm{wt} \%)>$ palm mesocarp fiber (34.3 $\mathrm{wt} \%$ ).

HTL in $\mathrm{N}_{2}$ environment produced highest bio-oil $(17 \mathrm{wt} \%)$, whereas it was lowest in case of $\mathrm{O}_{2}$. In $\mathrm{O}_{2}$ atmosphere oxidation of some phenolic derivative occurred.

At $410{ }^{\circ} \mathrm{C}$, highest conversion of $90 \%$ with heavy oil yield of $22 \mathrm{wt} \%$ and light oil yield of $12 \mathrm{wt} \%$ was obtained.

The gaseous fraction increased significantly at a temperature of $460^{\circ} \mathrm{C}$. 
Table 2. Cont

\begin{tabular}{ccc}
\hline S. No & Year & Description/Objective \\
\hline & & \\
& 2015 & $\begin{array}{c}\text { HTL of barley straw to bio-crude oil. } \\
\text { Understanding the effect of reaction } \\
\text { temperature and aqueous phase } \\
\text { recirculation. }\end{array}$
\end{tabular}


Table 2. Cont.

\begin{tabular}{|c|c|c|c|c|}
\hline S. No & Year & Description/Objective & Results/Observations/Major Findings & Ref. \\
\hline 19 & 2017 & $\begin{array}{l}\text { Co-liquefaction of spent coffee grounds } \\
\text { and lignocellulosic feedstocks. } \\
\text { Exploring the co-liquefaction of spent } \\
\text { coffee grounds with paper filter, corn } \\
\text { stalk, and white pine bark. } \\
\text { The main objective was to obtain possible } \\
\text { synergistic effect of different feedstock to } \\
\text { obtain bio-crude economically. }\end{array}$ & $\begin{array}{l}\text { The optimum temperature was } 250^{\circ} \mathrm{C} \text {, with mixing } \\
\text { biomass ratio of } 1: 1 \text {. } \\
\text { Spent coffee grounds and corn stalks were identified as } \\
\text { the best feedstock combination for co-liquefaction with a } \\
\text { significant positive synergistic effect. It was also found } \\
\text { that the overall oil quality improved in terms of viscosity } \\
\text { and relative molecular mass. }\end{array}$ & [82] \\
\hline 20 & 2020 & $\begin{array}{l}\text { HTL of lignocellulosic biomass feedstock } \\
\text { to produce biofuels: parametric study and } \\
\text { product characterization. }\end{array}$ & $\begin{array}{c}\text { Highest yield of heavy oil }(29.5 \mathrm{wt} \%) \text { was observed at } \\
300^{\circ} \mathrm{C} \text {, final pressure } 2200 \mathrm{psi} \text { and } 0 \text { min retention time. } \\
\text { The highest HHV was } 35.5 \mathrm{MJ} \mathrm{kg}{ }^{-1} \text { obtained for heavy } \\
\text { oil yielded at } 375^{\circ} \mathrm{C} \text {. }\end{array}$ & [24] \\
\hline 21 & 2020 & $\begin{array}{l}\text { Oil from plastic via HTL: production } \\
\text { and characterization. } \\
\text { Effect of resident time and temperature } \\
\text { was studied for HTL of polypropylene } \\
\text { (PP), polystyrene (PS), polycarbonate (PC), } \\
\text { and polyethylene terephthalate (PET). }\end{array}$ & $\begin{array}{l}\text { The highest oil yield for different plastic material was } \\
\text { found to be } 32 \mathrm{wt} \% \text { for } \mathrm{PP}\left(425^{\circ} \mathrm{C}, 30 \mathrm{~min}\right), 16 \mathrm{wt} \% \text { for } \\
\left.\text { PET ( } 450{ }^{\circ} \mathrm{C}, 30 \mathrm{~min}\right), 60 \mathrm{wt} \% \text { for } \mathrm{PC}\left(425^{\circ} \mathrm{C}, 30 \mathrm{~min}\right) \text {, } \\
\left.\text { and } 86 \mathrm{wt} \% \text { for PS ( } 350^{\circ} \mathrm{C}, 30 \mathrm{~min}\right) \text {. } \\
\text { Depolymerization of plastic was fastest in } \\
\text { supercritical water regime. } \\
\text { The HHV value of oil from PS and PP was } \\
\text { comparable to gasoline. }\end{array}$ & [83] \\
\hline 22 & 2020 & $\begin{array}{l}\text { Catalytic HTL of Lactuca scariola with a } \\
\text { heterogeneous catalyst: the investigation } \\
\text { of temperature, reaction time, and } \\
\text { synergistic effect of catalysts. }\end{array}$ & $\begin{array}{l}\text { The yield of light bio-oil increased on increasing } \\
\text { temperatures, from } 220^{\circ} \mathrm{C} \text { to } 280^{\circ} \mathrm{C} \text {, } \\
\text { and decreased afterwards. } \\
\text { The yield of heavy bio-oil increased with temperature, } \\
\text { whereas that of solid residue decreased. }\end{array}$ & [84] \\
\hline 23 & 2021 & $\begin{array}{l}\text { HTL of olive oil residue. } \\
\text { The objective was to obtain optimum } \\
\text { process parameters for HTL of olive oil } \\
\text { residue. }\end{array}$ & $\begin{array}{l}\text { Bio-oil and solid residue yield of } 30.8 \mathrm{wt} \% \text { and } 31.8 \mathrm{wt} \% \\
\text { was observed at optimum condition } 300{ }^{\circ} \mathrm{C} \text { and } \\
15 \mathrm{~min} \text {, respectively. }\end{array}$ & [85] \\
\hline 24 & 2021 & $\begin{array}{l}\text { Fast hydrothermal co-liquefaction of corn } \\
\text { stover }(\mathrm{CS}) \text { and cow manure }(\mathrm{CW}) \text { for } \\
\text { bio-crude and hydrochar production. } \\
\text { Several reaction parameters, such as } \\
\text { residence time, reaction temperature, and } \\
\text { feedstock mass ratio were studied. }\end{array}$ & $\begin{array}{l}\text { The highest yield of bio-crude was found to be over } \\
24 \mathrm{w} \% \text { at } 400^{\circ} \mathrm{C}, 16 \mathrm{~min} \text {, and CS:CW ratio of } 1: 1 \text {. } \\
\text { For a fixed temperature of } 400^{\circ} \mathrm{C} \text {, the yield of bio-crude } \\
\text { was maximum at CS:CM ratio of } 1: 1 \text {. } \\
\text { The percent of phenolic compound was found to increase } \\
\text { with residence time and was approximately } 42.92 \% \text { for } \\
30 \text { min residence time at } 400^{\circ} \mathrm{C} \text { and mass ratio } 1: 1 .\end{array}$ & [8] \\
\hline
\end{tabular}

\subsection{Temperature}

During most of the chemical process, temperature plays the main role in determining the reaction pathways and kinetics. Similarly, in the HTL process, temperature is a dominant factor, which decides major outcomes such as the total conversion of biomass, total yield of different products, and the physicochemical properties of the products. Table 3 includes articles focused on the effect of temperature on the HTL of biomass in a range of $180-400{ }^{\circ} \mathrm{C}$. The temperature helps to increase the hydrolysis rate for cellulose, hemicellulose, and lignin. It also promotes the fragmentation and degradation of lignocellulosic biomass. The main role of temperature is to overshoot the transition state/energy barrier between raw biomass and intermediates and move the process forward by providing enough potential energy for bond breaking. Thus, the initial rise in temperature promotes the endothermic step in the HTL process by providing the required activation energy for bond cessation. As the bonds break, many unstable entities - primarily free radicals and fragmented compounds-are formed. As the temperature is increased further, the excited radicals repolymerize by forming new bonds and releasing energy, making HTL exothermic in nature [86]. 
HTL process can have different optimal temperature points with respect to the total conversion, bio-crude yield, and solid char yield, as well as in the context of producing a higher fraction of a chemical composition in bio-crude. However, the present focus of the HTL process is to produce bio-crude, and in this review, we will focus on an optimal temperature for bio-crude yield. The optimal temperature in HTL depends on various parameters. The most important is the type and composition of biomass used in HTL. The type of solvents and catalysts, and the residence time, pressure, feed ratio, and heating rate also affect the preferred temperature.

Many research groups have focused on the liquefaction study of the model compound present in the lignocellulosic biomass. Minowa et al. [87] studied the decomposition of microcrystalline cellulose decomposition in the presence of hot compressed water. It was observed that on increasing the temperature from $200^{\circ} \mathrm{C}$ to $240^{\circ} \mathrm{C}$ all the products obtained through hydrolysis, such as glucose and oligomers, were water soluble in nature. Nonglucose products started forming only above $240{ }^{\circ} \mathrm{C}$. Simultaneously, primary products, such as char, oil, and gas also formed. There was a rapid increase in the decomposition of cellulose between 240 and $270^{\circ} \mathrm{C}$, with a complete disassociation of cellulose and maximum yield of glucose observed at $260^{\circ} \mathrm{C}$. When the temperature was increased further, the yield of the oil fraction increased and reached a maximum at $300{ }^{\circ} \mathrm{C}$. When the temperature exceeded $300^{\circ} \mathrm{C}$, the oil yield started to decrease, and the yield of char and gases started to increase.

Table 3. Effect of temperature on HTL process and products.

\begin{tabular}{|c|c|c|c|c|c|c|c|c|}
\hline Feedstock & $\begin{array}{l}\text { Process } \\
\text { Condition }\end{array}$ & $\begin{array}{c}\text { Product } \\
\text { Yield (wt\%) }\end{array}$ & $\begin{array}{c}\mathrm{HHV}^{*} \\
\left(\mathrm{MJ} \mathrm{kg}^{-1}\right)\end{array}$ & $\underset{(w t \%)}{C^{*}}$ & $\begin{array}{c}\mathbf{H}^{*} \\
(\mathbf{w t} \%)\end{array}$ & $\underset{(w t \%)}{O^{*}}$ & Oil Properties & Ref. \\
\hline $\begin{array}{l}\text { Wood } \\
\text { (konara) }\end{array}$ & $\begin{array}{c}\mathrm{T}^{*}: 250-400{ }^{\circ} \mathrm{C} \\
\mathrm{P}_{\mathrm{i}}^{*}: 2 \mathrm{MPa} \\
\mathrm{R}_{\mathrm{t}} *: 30 \mathrm{~min}\end{array}$ & $\begin{array}{l}\mathrm{HO}^{*}: \\
15-28.4\end{array}$ & $17.4-35.5$ & $63.8-77.9$ & $1.4-9.4$ & $14-34.7$ & - & [88] \\
\hline $\begin{array}{c}\text { Cunninghamia } \\
\text { lanceolata }\end{array}$ & $\begin{array}{c}\mathrm{T}: 280-360^{\circ} \mathrm{C} \\
\mathrm{R}_{\mathrm{t}}: 10 \mathrm{~min}\end{array}$ & $\begin{array}{c}\mathrm{HO}: \\
19.3-23.8\end{array}$ & $27.1-30.2$ & $69.6-75.1$ & $5.6-5.9$ & $19.2-24.8$ & - & [89] \\
\hline $\begin{array}{l}\text { High diversity } \\
\text { biomass }\end{array}$ & $300-450{ }^{\circ} \mathrm{C}$ & $\begin{array}{l}\mathrm{LP} * \\
64-74\end{array}$ & - & & & & $\begin{array}{c}\text { Acetic acid }(27 \%), \\
\text { ketones }(20 \%) \text {, aldehydes } \\
(4 \%), \text { benzenediols }(17 \%), \\
\text { phenolics }(26 \%), \text { phenyl } \\
\text { derivatives }(7 \%)\end{array}$ & [90] \\
\hline $\begin{array}{l}\text { Wood (Picea } \\
\text { orientalis) }\end{array}$ & \multirow{3}{*}{$\begin{array}{l}277-377{ }^{\circ} \mathrm{C} \\
\mathrm{R}_{\mathrm{t}}: 25 \mathrm{~min}\end{array}$} & $\begin{array}{c}\text { HO: } \\
13.8-25.8\end{array}$ & $28.3-31.9$ & 75.4 & 6.1 & 18.8 & - & \multirow{3}{*}{ [91] } \\
\hline $\begin{array}{l}\text { Wood } \\
\text { (Quercus } \\
\text { robur) }\end{array}$ & & $\begin{array}{c}\text { HO: } \\
15.9-27.1\end{array}$ & $27.9-31.6$ & 75.2 & 6.1 & 18.9 & - & \\
\hline $\begin{array}{l}\text { Wood (Fagus } \\
\text { orientalis) }\end{array}$ & & $\begin{array}{c}\text { HO: } \\
16.8-28.4\end{array}$ & $27.6-31.3$ & 75.1 & 6.0 & 19.1 & - & \\
\hline $\begin{array}{c}\text { Wood } \\
\text { (Paulownia) }\end{array}$ & $\begin{array}{c}280-3600^{\circ} \mathrm{C} \\
\mathrm{R}_{\mathrm{t}}: 10 \mathrm{~min} \\
60 \mathrm{~g} / 360 \mathrm{~mL}\end{array}$ & $\begin{array}{c}\text { HO: } \\
18.6-27\end{array}$ & 26.2 & 66.8 & 5.9 & 27.3 & - & {$[41]$} \\
\hline $\begin{array}{l}\text { Spirulina } \\
\text { platensis }\end{array}$ & $\begin{array}{c}200-380{ }^{\circ} \mathrm{C} \\
\mathrm{R}_{\mathrm{t}}: 60 \mathrm{~min} \\
20 \% \text { solid } \\
\text { concentration }\end{array}$ & $\begin{array}{c}\mathrm{BC}^{*}: \\
18-39.9\end{array}$ & $25.2-39.9$ & $55.5-82.1$ & $8.6-9.8$ & $0.6-28.9$ & - & [74] \\
\hline \multirow{2}{*}{$\begin{array}{l}\text { Cornelian } \\
\text { cherry stones }\end{array}$} & \multirow{2}{*}{$\begin{array}{c}200-300{ }^{\circ} \mathrm{C} \\
\mathrm{R}_{\mathrm{t}}: 0 \mathrm{~min}\end{array}$} & $\begin{array}{l}\mathrm{LO} *: \\
\sim 3-6\end{array}$ & $20.8-22.5$ & $58-60$ & $5.3-5.8$ & $34-36$ & $\begin{array}{l}\text { Acetic acid }(1.3-5 \%) \\
\text { phenolics }(10.8-39 \%), \\
\text { furfurals }(11-59 \%), \\
\text { vanillin }(\sim 3 \%)\end{array}$ & \multirow[t]{2}{*}{ [76] } \\
\hline & & $\begin{array}{c}\text { HO: } \\
\sim 10-22\end{array}$ & $25.5-25.6$ & $59.2-61.3$ & $7.2-7.9$ & $30.9-32.3$ & $\begin{array}{l}\text { Furfurals }(0.6-3.9 \%), \\
\text { phenolics }(\sim 5 \%),- \text { oic } \\
\text { acids }(45-61 \%)\end{array}$ & \\
\hline $\begin{array}{l}\text { Microcrystalline } \\
\text { cellulose }\end{array}$ & $\begin{array}{c}200-400{ }^{\circ} \mathrm{C} \\
\mathrm{R}_{\mathrm{t}}: 30 \mathrm{~min}\end{array}$ & $\begin{array}{c}\mathrm{HO}: \\
5-14.75\end{array}$ & 25.01 & 69.9 & 4.2 & 25.9 & $\begin{array}{l}\text { Acids }(14 \%) \text {, aldehydes } \\
(10 \%), \text { furans }(4 \%), \text { esters } \\
(28 \%) \text {, phenolics }(7 \%) \\
\text { ketones }(10 \%)\end{array}$ & {$[50]$} \\
\hline $\begin{array}{l}\text { Palm kernel } \\
\text { shell }\end{array}$ & $\begin{array}{c}330-360^{\circ} \mathrm{C} \\
\mathrm{P}: 25 \mathrm{MPa}\end{array}$ & $\begin{array}{c}\mathrm{BO} *: \\
22.8-38.5\end{array}$ & - & - & - & - & $\begin{array}{l}\text { Phenolics }(80.7 \%) \text {, other } \\
\text { aromatics }(6.4 \%) \text {, ketones } \\
(6.7 \%) \text {, alcohols }(3 \%), \\
\text { esters }(3.3 \%)\end{array}$ & {$[32]$} \\
\hline
\end{tabular}


Table 3. Cont

\begin{tabular}{|c|c|c|c|c|c|c|c|c|}
\hline Feedstock & $\begin{array}{l}\text { Process } \\
\text { Condition }\end{array}$ & $\begin{array}{c}\text { Product } \\
\text { Yield (wt } \%)\end{array}$ & $\begin{array}{c}\mathrm{HHV}^{*} \\
\left(\mathrm{MJ} \mathrm{kg}^{-1}\right)\end{array}$ & $\begin{array}{c}C^{*} \\
\left(w t^{\circ} \%\right)\end{array}$ & $\underset{(\mathbf{w t} \%)}{\mathrm{H}^{*}}$ & $\underset{\left(w t^{\circ} \%\right)}{O *}$ & Oil Properties & Ref. \\
\hline $\begin{array}{l}\text { Empty fruit } \\
\text { bunch }\end{array}$ & $\begin{array}{l}330-360^{\circ} \mathrm{C} \\
\mathrm{P}: 25 \mathrm{MPa}\end{array}$ & $\begin{array}{c}\text { BO: } \\
15.7-37.4\end{array}$ & - & - & - & - & $\begin{array}{c}\text { Phenolics }(72.8 \%), \text { other } \\
\text { aromatics }(10.7 \%) \\
\text { ketones }(16.5 \%)\end{array}$ & \\
\hline $\begin{array}{l}\text { Swine } \\
\text { carcasses }\end{array}$ & $\begin{array}{l}\mathrm{T}: 150-400{ }^{\circ} \mathrm{C} \\
\mathrm{R}_{\mathrm{t}}: 60 \mathrm{~min} \\
\mathrm{pH}: 11\end{array}$ & $\begin{array}{c}\text { BO: } \\
40.1-58.2\end{array}$ & 32.3 & 75 & 13.7 & 8.4 & $\begin{array}{c}\text { Phenyl der }(21 \%), \\
\text { ketones }(8.5 \%), \text { furfurals } \\
(5 \%) \text {, aldehydes }(3.7 \%), \\
\text { fatty acids }(13)\end{array}$ & [92] \\
\hline Barley straw & $\begin{array}{c}\mathrm{T}: 280-400{ }^{\circ} \mathrm{C} \\
\text { Catalyzed }\end{array}$ & $\begin{array}{c}\text { BC: } \\
19.9-34.9\end{array}$ & $26.8-35.5$ & - & - & - & $\begin{array}{c}\text { Phenolics }(5 \%), \text { FAAE * } \\
(20 \%), \text { ketones }(3-4 \%), \\
\text { cresol }(2 \%) \text {, catechol }(3 \%), \\
\text { alcohols }\end{array}$ & [27] \\
\hline $\begin{array}{l}\text { Spent coffee } \\
\text { grounds }\end{array}$ & $\begin{array}{c}\mathrm{T}: 200-300{ }^{\circ} \mathrm{C} \\
\mathrm{P}_{\mathrm{i}}: 2 \mathrm{MPa}, \\
\mathrm{R}_{\mathrm{t}}: 10 \mathrm{~min}\end{array}$ & $\begin{array}{c}\text { BC: } \\
16.6-35.3\end{array}$ & 31 & 71.2 & 7.1 & 18.7 & $\begin{array}{c}\text { Hexadecanoic acid (48\%), } \\
\text { octadecanoic acid }(15 \%), \\
\text { octadecadienoic acid } \\
(35 \%)\end{array}$ & [79] \\
\hline $\begin{array}{c}\text { Waste bamboo } \\
\text { chopstick }\end{array}$ & $\begin{array}{c}\mathrm{T}: 290-380{ }^{\circ} \mathrm{C} \\
\text { Catalyzed }\end{array}$ & $\begin{array}{c}\text { BO: } \\
7.1-21.2\end{array}$ & 29.7-31 & $66.4-74.2$ & $6.7-7.4$ & $18.4-25.1$ & - & [80] \\
\hline $\begin{array}{l}\text { Blackcurrant } \\
\text { pomace }\end{array}$ & $\begin{array}{c}\mathrm{T}: 290-335^{\circ} \mathrm{C} \\
\mathrm{R}_{\mathrm{t}}: 60 \mathrm{~min}\end{array}$ & $\begin{array}{c}\text { BO: } \\
25.5-30\end{array}$ & 35.9 & 73.3 & 9.6 & 13.6 & $\begin{array}{c}\text { Ketones (6\%), FAAE }(3 \%), \\
\text { FA * }(30 \%), \text { FAM }(10 \%), \\
\text { phenolics }(9 \%)\end{array}$ & [81] \\
\hline Coconut shell & $\begin{array}{c}\mathrm{T}: 240-330{ }^{\circ} \mathrm{C} \\
\mathrm{R}_{\mathrm{t}}: 30 \mathrm{~min}\end{array}$ & $\begin{array}{c}\text { BO: } \\
7-13.9\end{array}$ & 29.9-31.1 & - & - & - & $\begin{array}{c}\text { Ketones }(0.1-2.7 \%), \\
\text { phenol }(1.1-6 \%), \text { acids } \\
(0.3-1.7 \%), \text { furfurals } \\
(4-6 \%), \text { polyols and } \\
\text { alcohols }(0.4-6.3 \%)\end{array}$ & [93] \\
\hline $\begin{array}{l}\text { Spent coffee } \\
\text { ground + corn } \\
\text { stalk }\end{array}$ & $\begin{array}{l}\mathrm{T}: 225-325{ }^{\circ} \mathrm{C} \\
\mathrm{R}_{\mathrm{t}}: 10 \mathrm{~min}\end{array}$ & $\begin{array}{c}\text { BC: } \\
10.2-21.6\end{array}$ & 33.3 & - & - & - & $\begin{array}{l}\text { Long chain } \\
\text { carboxylic acids }\end{array}$ & [82] \\
\hline \multirow[t]{2}{*}{ Rice straw } & \multirow[t]{2}{*}{$\begin{array}{c}\mathrm{T}: 200-300{ }^{\circ} \mathrm{C} \\
\mathrm{R}_{\mathrm{t}}: 120 \mathrm{~min}\end{array}$} & $\begin{array}{c}\text { LO: } \\
4.9-11.7\end{array}$ & $22.2-24.9$ & $58.6-61.1$ & $5.9-6.9$ & $31.4-34.4$ & $\begin{array}{l}\text { Fatty acids, carboxylic } \\
\text { acids, furan, aldehydes, } \\
\text { esters, phenols, ketones, } \\
\text { alcohols, alkenes, alkanes }\end{array}$ & \multirow[t]{2}{*}[26]{} \\
\hline & & $\begin{array}{l}\mathrm{HO}: \\
8.8-15.9\end{array}$ & $22.4-31.9$ & $58.6-72.7$ & $6.5-7.5$ & $18.8-34.8$ & $\begin{array}{l}\text { Carboxylic acids, ketones, } \\
\text { alkanes, alcohols, amines, } \\
\text { phenols }\end{array}$ & \\
\hline Corn stover & $\begin{array}{c}\mathrm{T}: 250-375^{\circ} \mathrm{C} \\
\mathrm{R}_{\mathrm{t}}: 15 \mathrm{~min} \\
\mathrm{P}_{\mathrm{i}}: 4 \mathrm{MPa}\end{array}$ & $\begin{array}{c}\text { HO: } \\
14.3-27.2\end{array}$ & $27.5-35.1$ & $64.9-76.3$ & $7.2-8.2$ & $13.6-26.5$ & $\begin{array}{c}\text { Ketones }(2.1-9.6 \%), \text { linear } \\
\text { saturated and } \\
\text { unsaturated HC }(1-12 \%), \\
\text { phenyl compounds } \\
(3-7 \%), \text { phenolic } \\
\text { derivatives (56-82\%), } \\
\text { aldehydes, fatty acids, } \\
\text { and fatty acid } \\
\text { alkyl esters. }\end{array}$ & {$[14,24]$} \\
\hline $\begin{array}{l}\text { Olive oil } \\
\text { residue }\end{array}$ & $\begin{array}{c}\mathrm{T}: 250-330{ }^{\circ} \mathrm{C} \\
\mathrm{R}_{\mathrm{t}}: 15 \mathrm{~min}\end{array}$ & $\begin{array}{c}\text { BO: } \\
14.79-30.75\end{array}$ & $25.6-31.8$ & $63.8-70.9$ & $6.6-7.9$ & $19.9-28.5$ & $\begin{array}{c}\text { Ketones }(17.81 \%), \\
\text { phenols }(43.56 \%), \text { acids } \\
(0.69 \%), \text { and esters } \\
(10.47 \%)\end{array}$ & [85] \\
\hline
\end{tabular}

* HO: heavy oil, BO: bio-oil, BC: bio-crude, LO: light oil, LP: liquid products, HHV; higher heating value, C: carbon, H: hydrogen, O: oxygen; $\mathrm{P}_{\mathrm{i}}$ : initial pressure, $\mathrm{P}_{\mathrm{f}}$ : final pressure, $\mathrm{T}$ : temperature, $\mathrm{R}_{\mathrm{t}}$ : retention time, FAAE: fatty acid alkyl ester, FA: fatty acids.

Arturi et al. [53] studied the liquefaction of lignin near critical water, at a temperature range of $280-350{ }^{\circ} \mathrm{C}$ in the presence of $\mathrm{K}_{2} \mathrm{CO}_{3}$ as a catalyst, and a 3.2-3.6 wt\% of phenol. The results indicated a significant increase in bio-crude yield from $50.6 \mathrm{wt} \%$ to $77 \mathrm{wt} \%$ when the temperature increased from $280{ }^{\circ} \mathrm{C}$ to $300{ }^{\circ} \mathrm{C}$, followed by a steep decrease to $50.4 \mathrm{wt} \%$ when the temperature increased to $320^{\circ} \mathrm{C}$. Similar trends of lignin decomposition were also observed by Nguyen et al. [56]. The yield of oil was around $85-88 \mathrm{wt} \%$ at a lower temperature of $290-310^{\circ} \mathrm{C}$, which decreased to $69 \mathrm{wt} \%$ when the temperature was increased to $370{ }^{\circ} \mathrm{C}$, whereas the fraction of char and water-soluble hydrocarbon increased with an increase in temperature. Both Arturi et al. [53] and Nguyen et al. [56] observed that the total phenol-free mass fraction increased with an increase in temperature. The mass fraction of catechol and alkyl phenols (methyl, ethyl) also increased with a temperature increase. 
However, the mass fraction of guaiacols, phenolic dimers, vanillin, and acetovanillone decreased with an increase in temperature.

Mathanker et al. [24] published a parametric study to understand how the process parameters, such as temperature $\left(250-375^{\circ} \mathrm{C}\right)$, pressure $\left(\mathrm{P}_{\mathrm{i}}: 2-4 \mathrm{MPa}\right)$, and retention time (0-60 $\mathrm{min})$ affect the liquefaction of corn stover. It was observed that for the fixed initial pressure of $4 \mathrm{MPa}$ and retention time of $15 \mathrm{~min}$, a yield of heavy oil reached a maximum limit with an increase in temperature from $250{ }^{\circ} \mathrm{C}(22.2 \mathrm{wt} \%)$ to $300^{\circ} \mathrm{C}(27.2 \mathrm{wt} \%)$, where the yield of solid char was minimum. This was followed by a steep decrease in the oil yield as the temperature rose to the super critical point of water $375^{\circ} \mathrm{C}(14.3 \mathrm{wt} \%)$. However, it was observed that, though the yield of solid char was minimum at $300{ }^{\circ} \mathrm{C}(21.4 \mathrm{wt} \%)$, it increased with a further increase in temperature to $350{ }^{\circ} \mathrm{C}(26.8 \mathrm{wt} \%)$, followed by a decrease in the second half when the temperature increased to $375^{\circ} \mathrm{C}(22.4 \mathrm{wt} \%)$.

Zhu et al. [27] showed the HTL of barley straw in a temperature range of $280-400{ }^{\circ} \mathrm{C}$ with $\mathrm{K}_{2} \mathrm{CO}_{3}$ as a catalyst. Initially, in a low temperature range of $280-320^{\circ} \mathrm{C}$, there was no significant change in the yield of products, mostly due to the continuous hydrolysis and dehydration reaction, giving rise to the formation of intermediates. The maximum yield of bio-oil occurred at $300{ }^{\circ} \mathrm{C}(34.9 \mathrm{wt} \%)$, which decreased with an increase in temperature to $400{ }^{\circ} \mathrm{C}(19.9 \mathrm{wt} \%)$. The study also indicated a decrease in the oil yield and an increase in the solid char yield as the temperature increased from $320-400{ }^{\circ} \mathrm{C}$. Sun et al. [41] performed the liquefaction of paulownia in hot compressed water in a temperature range of $280-360^{\circ} \mathrm{C}$, and obtained a similar trend of an increase in the heavy oil yield mass fraction from 280 to $300{ }^{\circ} \mathrm{C}$, followed by a continuous decrease to $360^{\circ} \mathrm{C}$. Khampuang et al. [94] examined the effect of temperature on the liquefaction of corncobs in supercritical ethanol for $60 \mathrm{~min}$ and under an initial $\mathrm{H}_{2}$ pressure of $4 \mathrm{MPa}$ and reported that the oil yield gradually increased from $300{ }^{\circ} \mathrm{C}(33.9 \mathrm{wt} \%)$ to $340{ }^{\circ} \mathrm{C}(38.6 \mathrm{wt} \%)$, followed by a steep decrease at $360{ }^{\circ} \mathrm{C}$ (27.3 wt\%). In the co-liquefaction study carried out by Yang et al. [82] on spent coffee grounds with lignocellulosic feedstocks (paper filter, corn stalk, and white pine bark), the optimum temperature for maximum bio-crude yield was found to be $250^{\circ} \mathrm{C}$, whereas the liquefaction of the spent coffee grounds alone in Yang et al. [79] showed the optimum temperature to be $275^{\circ} \mathrm{C}$.

Most of the studies that used agricultural crop residue, forest biomass residue, marine biomass waste, and municipal solid waste as feedstock observed that, with an increase in temperature, the bio-oil yield increased to a maximum, as shown in Figure 5; any further increase in temperature resulted in a decrement in the mass fraction of bio-oil. It can be said that the intermediate temperature range of $275-350{ }^{\circ} \mathrm{C}$ supports a higher oil yield. At a lower temperature range, $<275^{\circ} \mathrm{C}$, the biomass is not completely degraded, leading to a higher unconverted solid residue. Moreover, the reactions are predominantly endothermic, supporting the formation of water-soluble organics and unstable entities. Even a higher temperature (i.e., $>350{ }^{\circ} \mathrm{C}$ ) does not favor bio-oil production as with an increase in temperature the yield of solid and gas fraction increases. One possible reason could be the promotion of the Boudouard reaction and hydrocracking at higher temperatures. The Boudouard reaction between char and carbon dioxide, which produces carbon monoxide, is endothermic in nature and is thus suppressed at a lower temperature, where much of the supplied energy is used in the decomposition of biomass. However, at temperatures near $374{ }^{\circ} \mathrm{C}$, much of the repolymerization reaction and the resulting bond formation release essential energy required to promote a side reaction supporting gas formation [3]. Secondly, the formation of char that results from a repolymerization/condensation reaction due to the availability of free radicals in the process leads to a decrease in the oil yield [27,86]. Hence, it is the competition among the initial hydrolysis process, secondary repolymerization, and cracking reaction, which decides the optimum temperature for the oil yield from a biomass. 


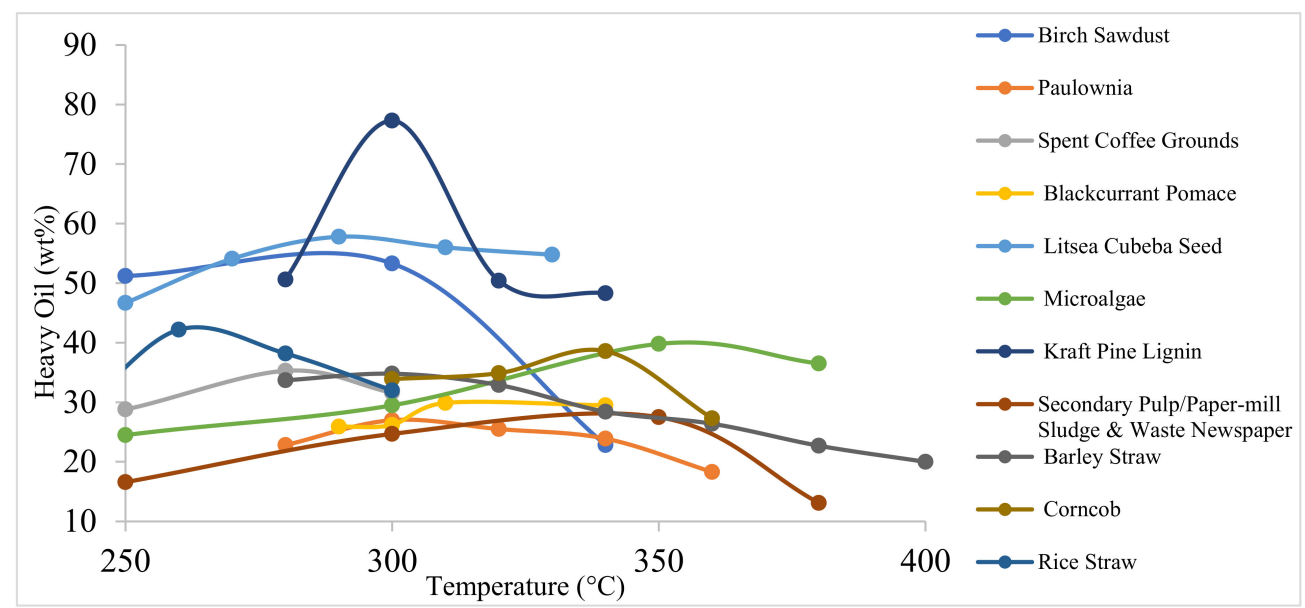

Figure 5. Effect of final temperature on the yield of heavy oil for various feedstocks.

\subsection{Pressure}

Reactor pressure is another important parameter that can simultaneously promote and hinder various reactions during the HTL process. In general, $\mathrm{N}_{2}, \mathrm{He}$, or Ar is used as an inert media $[88,95,96]$, as summarized in Table 4 . Hydrothermal liquefaction occurs at a temperature above the boiling point of water. Most of the solvents used in the study, such as water, ethanol, methanol, DCM, acetone, phenol, and ethylene glycol, have a boiling point below $100{ }^{\circ} \mathrm{C}$ in atmospheric pressure conditions. During high temperature operations, the inclination of these solvents is to split into two phases by exploiting the system's energy. An initial pressure maintained in the system helps to lessen the phase transition of the solvent into vapor during subcritical and supercritical operations, thus reducing the additional energy required to support a two-phase system [14,79].

Table 4. Effect of pressure on HTL process.

\begin{tabular}{|c|c|c|c|c|c|c|c|c|}
\hline Feedstock & $\begin{array}{l}\text { Process } \\
\text { Condition }\end{array}$ & $\begin{array}{c}\text { Product } \\
\text { Yield (wt\%) }\end{array}$ & $\underset{\left(\mathrm{MJ} \mathrm{kg}^{-1}\right)}{\mathrm{HHV}^{*}}$ & $\underset{(w t \%)}{C^{*}}$ & $\underset{\left(w t^{*} \%\right)}{\mathbf{H}^{*}}$ & $\underset{(w t \%)}{O *}$ & Oil Properties/Comments & Ref. \\
\hline $\begin{array}{l}\text { Wood } \\
\text { (konara) }\end{array}$ & $\begin{array}{c}\mathrm{P}_{\mathrm{i}}^{*}: \\
0.5-10 \mathrm{MPa} \\
\mathrm{T}^{*}: 350{ }^{\circ} \mathrm{C} \\
\mathrm{R}_{\mathrm{t}}^{*}: 30 \mathrm{~min}\end{array}$ & $\begin{array}{l}\mathrm{HO}^{*}: \\
5.9-20.1\end{array}$ & $31.6-35.5$ & $73.6-76.9$ & $7-8.1$ & $13.9-19.4$ & $\begin{array}{l}\text { The yield was remarkably dependent on } \\
\text { pressure and maxed at initial pressure } \\
\text { of } 4.0 \mathrm{MPa} \text {. }\end{array}$ & [88] \\
\hline \multirow{2}{*}{$\begin{array}{l}\text { Birch } \\
\text { powder }\end{array}$} & $\begin{array}{l}\mathrm{P}_{\mathrm{i}}: 0-10 \mathrm{MPa} \\
\mathrm{T}: 200{ }^{\circ} \mathrm{C} \\
\mathrm{R}_{\mathrm{t}}: 30 \mathrm{~min}\end{array}$ & $\mathrm{HO}: 3-5.8$ & - & - & - & - & \multirow{2}{*}{$\begin{array}{l}\text { There was a sharp increase in oil yield } \\
\text { on increasing pressure from } 0 \text { to } 2 \mathrm{MPa} \\
\text { followed by a decrease in yield on } \\
\text { further increasing pressure until } 9 \mathrm{MPa} \text {. }\end{array}$} & \multirow[t]{2}{*}{ [97] } \\
\hline & $\begin{array}{c}\mathrm{P}_{\mathrm{i}}: 0-10 \mathrm{MPa} \\
\mathrm{T}: 300{ }^{\circ} \mathrm{C} \\
\mathrm{R}_{\mathrm{t}}: 30 \mathrm{~min}\end{array}$ & HO: 9.2-12.7 & - & - & - & - & & \\
\hline $\begin{array}{l}\text { Red pine } \\
\text { sawdust }\end{array}$ & $\begin{array}{l}\text { Pi: } 0.4-7.5 \\
\text { MPaT: } \\
370{ }^{\circ} \mathrm{C}, \mathrm{R}_{\mathrm{t}} \text { : } \\
30 \mathrm{~min}\end{array}$ & $\mathrm{BC}^{*}: 52-56$ & - & - & - & - & $\begin{array}{l}\text { H/C: } 1.43-1.47, \mathrm{O} / \mathrm{C}: 0.28-0.34 \\
\text { The initial pressure head had negligible } \\
\text { effect on conversion, bio-crude, and } \\
\text { solid yield. }\end{array}$ & [98] \\
\hline \multirow{3}{*}{$\begin{array}{l}\text { Palm } \\
\text { mesocarp } \\
\text { fiber }\end{array}$} & $\begin{array}{l}\mathrm{P}: 25-35 \mathrm{MPa} \\
\mathrm{T}: 390{ }^{\circ} \mathrm{C}\end{array}$ & $\begin{array}{c}\mathrm{BO} *: \\
29.4-38.5\end{array}$ & \multirow{3}{*}{-} & \multirow{3}{*}{-} & \multirow{3}{*}{-} & \multirow{3}{*}{-} & $\begin{array}{c}\text { Phenolics }(89.4 \%) \text {, other aromatics } \\
(5.3 \%), \text { ketones }(5.3 \%)\end{array}$ & \multirow{3}{*}[32]{} \\
\hline & $\begin{array}{l}\mathrm{P}: 25-35 \mathrm{MPa} \\
\mathrm{T}: 360{ }^{\circ} \mathrm{C}\end{array}$ & BO: $23.4-27.5$ & & & & & $\begin{array}{l}\text { The decreased bio-oil yield at higher } \\
\text { pressure in supercritical condition was }\end{array}$ & \\
\hline & $\begin{array}{l}\mathrm{P}: 25-35 \mathrm{MPa} \\
\mathrm{T}: 330{ }^{\circ} \mathrm{C}\end{array}$ & BO: $22.8-25.6$ & & & & & $\begin{array}{l}\text { attributed to be the result of gasification } \\
\text { due to increased free radical reaction. }\end{array}$ & \\
\hline $\begin{array}{l}\text { Poplar } \\
\text { wood }\end{array}$ & P: 0-4 MPa & BO: $16-18$ & 26.8 & 66.3 & 6.4 & 27.1 & $\begin{array}{l}\text { Bio-oil yield increased while solid } \\
\text { residue decreased with the increase } \\
\text { in pressure. }\end{array}$ & [37] \\
\hline \multirow{2}{*}{$\begin{array}{l}\text { Corn } \\
\text { stover }\end{array}$} & $\begin{array}{l}\mathrm{P}_{\mathrm{i}}: 2-4 \mathrm{MPa} \\
\mathrm{T}: 300{ }^{\circ} \mathrm{C}\end{array}$ & $\begin{array}{c}\mathrm{HO}: \\
21.8-27.2\end{array}$ & $29.6-30.3$ & $68.3-69.4$ & $7.4-7.5$ & $21.5-22.7$ & \multirow{2}{*}{$\begin{array}{c}\text { Effect of pressure was obvious in } \\
\text { sub-critical temperature and negligible } \\
\text { near supercritical condition. }\end{array}$} & \multirow{2}{*}{ [24] } \\
\hline & $\begin{array}{l}\mathrm{P}_{\mathrm{i}}: 2-4 \mathrm{MPa} \\
\mathrm{T}: 375^{\circ} \mathrm{C}\end{array}$ & $\begin{array}{l}\text { HO: } 14.3 \\
\text { (No change) }\end{array}$ & 35.1 & 76.3 & 8.2 & 13.6 & & \\
\hline
\end{tabular}

* HO: heavy oil, BO: bio-oil, BC: bio-crude, HHV; higher heating value, C: carbon, $\mathrm{H}$ : hydrogen, O: oxygen, $\mathrm{P}_{\mathrm{i}}$ : initial pressure, $\mathrm{P}_{\mathrm{f}}$ : final pressure, $T$ : temperature, $R_{t}$ : retention time. 
In a subcritical region, an increase in the operating pressure increases the local density of the solvent. An increase of pressure at $330^{\circ} \mathrm{C}$ from 25 to $35 \mathrm{MPa}$ increases water density by $22 \mathrm{~kg} \mathrm{~m}^{-3}$ and at $360{ }^{\circ} \mathrm{C}$ by $44 \mathrm{~kg} \mathrm{~m}^{-3}$ [32]. The increase in local solvent density allows more contact and better penetration and interaction of hydrolysis ions with the crystallized zone of cellulose and the surface of cellulose, hemicellulose, and lignin. Once the supercritical condition is achieved, the pressure has a negligible impact on the yield of bio-oil $[24,98]$. The increase of pressure in the supercritical region increases the local solvent density, causing a cage effect, which prevents $\mathrm{C}-\mathrm{C}$ bond cleavage and thus reducing the fragmentation of lignocellulosic material [86]. However, Chan et al. [28] performed liquefaction of three forms of oil palm biomass (empty fruit bunch, palm mesocarp fiber, and palm kernel shell) in a supercritical zone $\left(390^{\circ} \mathrm{C}\right)$ and observed a decrease in the bio-oil yield by $6-9 \mathrm{wt} \%$ when the operating pressure was increased from 25 to $30 \mathrm{MPa}$. In the supercritical region, the effect of the pressure on the kinetics of the hydrolysis reaction is relatively small. Even a pressure of 30-40 MPa may not be adequate to affect the hydrolysis rate [99]. However, the selectivity of the cellobiose hydrolysis reaction increases. For example, when the pressure is increased above the critical point, the isomerization rate of glucose to fructose decreases and the retro-aldol condensation of glucose increases, whereas with a decrease in pressure, the formation of 5-HMF and hydrolysis of oligosaccharides increases [100].

In early studies, Ogi et al. [88] observed that on increasing initial pressure from 0.5 to $4 \mathrm{MPa}$, the bio-oil yield increased from 6 to $20 \mathrm{wt} \%$ and had a negligible effect on a further increase in pressure up to $10 \mathrm{MPa}$ at $350^{\circ} \mathrm{C}$. Mathanker et al. [24] observed that pressure had no effect on oil yield in the supercritical region $\left(374{ }^{\circ} \mathrm{C}\right)$, whereas at a $300^{\circ} \mathrm{C}$ increase in initial pressure from 2 to $4 \mathrm{MPa}$, there was an increase in the bio-oil yield from $21 \mathrm{wt} \%$ to $27 \mathrm{wt} \%$. Similarly, Brand et al. [98], Yang et al. [79], and Tekin et al. [37] observed that an initial pressure of inert $\mathrm{N}_{2}$ had little effect on the yield of bio-oil. They also found that a starting pressure of 4-5 MPa helps to improve the yield of bio-oil as shown in Figure 6. In the case of gaseous products, the role of pressure becomes significant after the critical point of water; an increase in pressure above the critical point favors the formation of $\mathrm{C}_{2}$, $\mathrm{C}_{3}$, and $\mathrm{C}_{4}$, and decreases yield of $\mathrm{H}_{2}$ and $\mathrm{CO}_{2}$ [101].

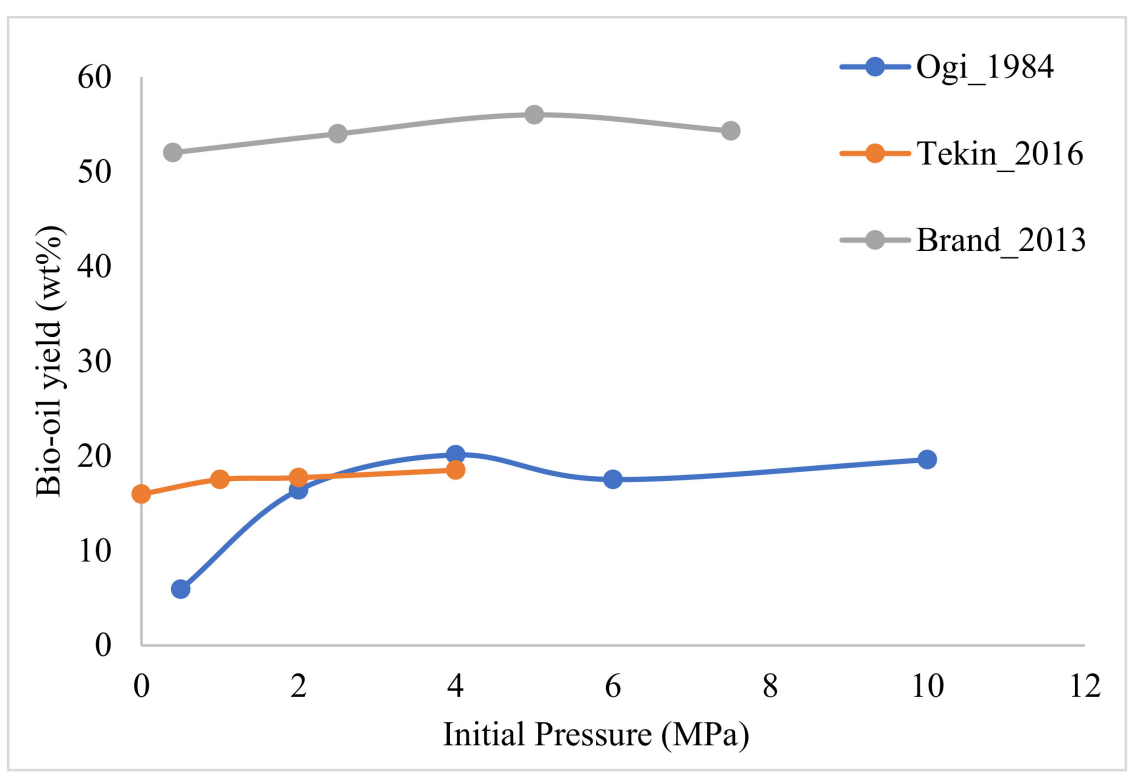

Figure 6. Effect of initial pressure in reactor on the yield of bio-oil (inert environment).

In order to understand the effect of various reaction environments, other gaseous systems, such as $\mathrm{H}_{2}[96,97,102], \mathrm{CO}_{2}$ [77], $\mathrm{O}_{2}$ [77], and $\mathrm{CO}$ [95], are also used. Yin et al. [95] performed HTL of cattle manure in the presence of $\mathrm{CO}$ and $\mathrm{N}_{2}$ at $310{ }^{\circ} \mathrm{C}$ and observed that $\mathrm{CO}$ was the most effective process gas. Furthermore, an increase in initial pressure from 0 
to $0.7 \mathrm{MPa}$ was shown to decrease the bio-oil yield from $48.8 \mathrm{wt} \%$ to $8.6 \mathrm{wt} \%$. Xu et al. [96] conducted a process gas study using $2 \mathrm{MPa}$ initial pressure of $\mathrm{H}_{2}$ and $\mathrm{N}_{2}$ for liquefaction of pulp paper sludge and recorded that in the presence of a $\mathrm{Ca}(\mathrm{OH})_{2}$ catalyst at $280{ }^{\circ} \mathrm{C}$, the yield of heavy oil was twice in case of $\mathrm{H}_{2}$ when compared to an inert $\mathrm{N}_{2}$ system. Singh et al. [77] examined the reaction environment of $\mathrm{N}_{2}, \mathrm{O}_{2}$, and $\mathrm{CO}_{2}$ for liquefaction of rice straw and observed the highest yield of bio-oil in the $\mathrm{N}_{2}$ environment and the lowest in the presence of $\mathrm{O}_{2}$. The oil obtained in the presence of $\mathrm{O}_{2}$ showed a higher aliphatic proton content whereas the oil in the presence of $\mathrm{N}_{2}$ and $\mathrm{CO}_{2}$ was rich in aromatic proton contents.

All the parameters are interlinked from the standpoint of mass production, as discussed in Elliot et al. [10]. To commercialize a continuous system, we need a small reactor size, which can effectively handle high concentrated feed at high temperatures and have low residence time to achieve required conversion. At high temperatures, pressure is necessary to maintain a single-phase system in the reactor. The operating pressure selected should be able to maintain a single phase so that the liquid water slurry can be easily transported in a continuous HTL system. Hence, pressure is an important factor to maintain a single-phase system for the reaction to progress smoothly.

\subsection{Retention Time}

The term retention time, also known as residence time, is defined as the period during which the reactor is maintained at the required temperature, i.e., not including the heating and cooling, as shown in Figure 7.

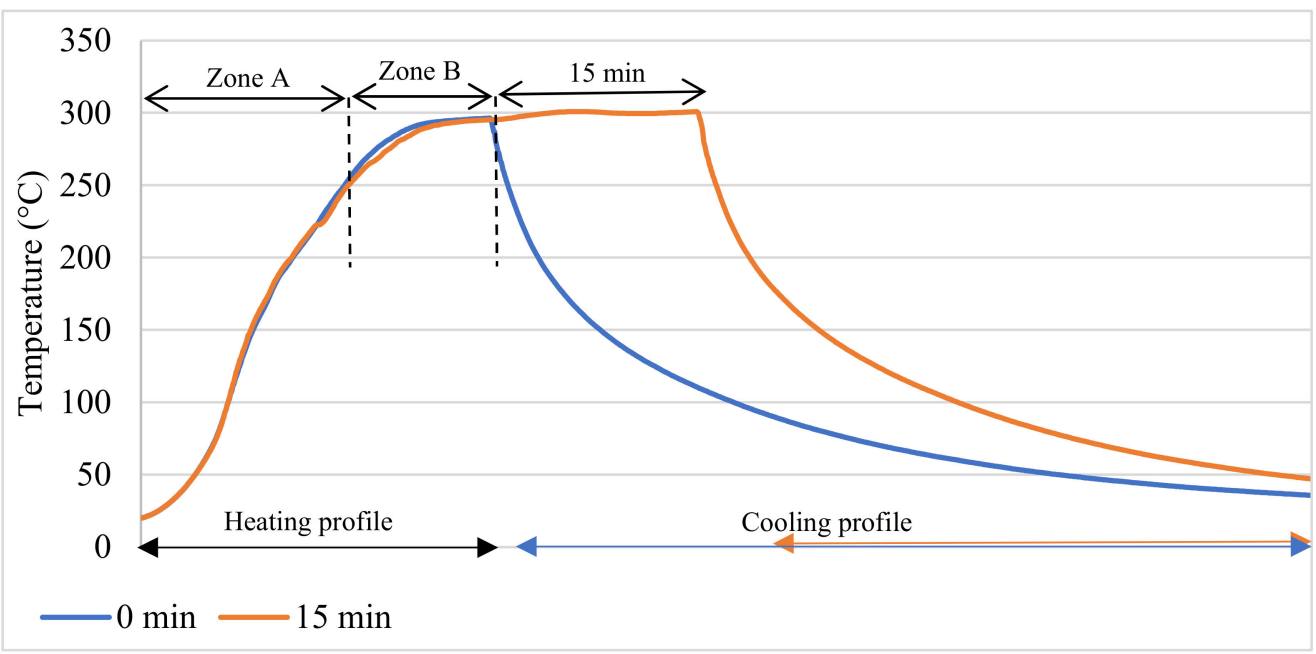

Figure 7. Heating and cooling cycle of the reactor for $\mathrm{HTL}$ at $300^{\circ} \mathrm{C}$ for 0 and $15 \mathrm{~min}$ retention time (adapted from [24]).

Retention time affects most major outcomes, such as biomass conversion, yield of products, and composition. The selection of optimum retention time depends on many parameters, mainly temperature, heating rate, and catalysts. Using a low heating rate means it will take longer to reach the final temperature, which provides more time for biomass conversion and oil formation, ultimately reducing the need for a longer retention time. Similarly, the hydrolysis takes place faster in the critical temperature zone and in the presence of alkalis, reducing the need for an increased retention time.

Many studies have been conducted to determine the effect of retention time over a wide range of biomass, as reviewed in Table 5. Xu et al. [96] conducted an HTL of secondary pulp/paper sludge at $280^{\circ} \mathrm{C}$, without a catalyst, for a retention time of 15-120 min and observed that a yield of heavy oil increased with the increase in time and that the watersoluble organics decreased. It was thought that the increased time allowed carbohydrates and formic/acetic acids from the WSO to dehydrate, adding to the HO mass fraction. During the HTL of wood, Ogi et al. [88] found that the maximum yield of oil was obtained 
at $0 \mathrm{~min}(24.6 \mathrm{wt} \%)$ and the yield of oil decreased continuously afterwards, up to $180 \mathrm{~min}$ (14.7 wt\%). Similarly, Qu et al. [89] found a decrease in bio-oil with an increase in retention time for the HTL of Cunninghamia lanceolate, which was mainly due to condensation and the repolymerization of intermediates to form solid products as a result of prolonged exposure of intermediates to high temperature. Later, Yang et al. [79] observed that a 10-min retention time was adequate to break down biomass and achieve the highest yield of crude bio-oil. A further increase in the retention time resulted in the decomposition of crude bio-oil into lighter products and gases.

In contrast to the above outcomes, several other studies support longer retention times, finding that they are more favorable in increasing the yield. Yang et al. [97] examined the liquefaction of birch powder with a methanol solvent for a retention time of 10 to $480 \mathrm{~min}$ above the supercritical condition of methanol and found that the conversion and yield of all gas, heavy oil, and water-soluble organics increased with an increase in reaction time. Yang et al. [89] also concluded that sub/supercritical alcohol readily dissolves the unstable liquid intermediates, which ultimately prevents the heavy oil from condensing into char. Yim et al. [103] explored the effect of retention time on the relative yield of bio-oil in the presence of four metal oxide catalysts $\left(\mathrm{La}_{2} \mathrm{O}_{3}, \mathrm{CeO}_{2}, \mathrm{CaO}\right.$, and $\left.\mathrm{MnO}\right)$ at $390{ }^{\circ} \mathrm{C}$. He found that the relative yield of bio-oil increased on increasing retention time from $15 \mathrm{~min}$ to $60 \mathrm{~min}$, indicating that the cleavage of $\mathrm{C}-\mathrm{C}$ bonds in biomass led to the dehydration, decomposition, and recombination of fragments that were added to the biooil. However, a prolonged time-between 60 and 960 min-resulted in a decrease in the relative bio-oil yield, mainly due to cracking of bio-oil in low molecular gaseous products, and repolymerization of intermediates into solid char. A short retention time can lead to the incomplete decomposition of biomass, whereas a longer-than-needed retention time can promote repolymerization/carbonization and the cracking of oil and organics into char and gas, along with an increase in operational costs.

\subsection{Heating Rate}

The heating rate, defined as the rate of temperature increase per unit time, is another important parameter during liquefaction. Figure 7 shows the heating and cooling cycle for the HTL batch reactor. As shown in Figure 7, the heating cycle for an electrically heated batch autoclave reactor can be divided in two zones. Zone $\mathrm{A}$ and $\mathrm{B}$ have a heating rate of $10{ }^{\circ} \mathrm{C} \min ^{-1}$ and $2.5^{\circ} \mathrm{C} \mathrm{min}^{-1}$, respectively [24]. In general, biomass spends a larger part of the heating period in a high subcritical temperature range (Zone $\mathrm{B}$ ) before reaching the desired reaction temperature. Thus the majority of the reactions that occurred during the HTL process were completed during the long heating cycle [81].

The studies that look at the effect of the heating rate on the HTL of wood and agricultural biomass, as shown in Table 6, are very limited when compared to other techniques of bio-oil production, such as pyrolysis. In pyrolysis, the heating rate is a wellestablished parameter affecting the yield of products. Tran et al. [104] used a heating rate of 66-179 ${ }^{\circ} \mathrm{C} \mathrm{min}^{-1}$ at $350{ }^{\circ} \mathrm{C}$ to determine trends in the bio-oil yield from spruce wood; the results indicated a positive trend of a continuous increase in bio-oil yield with an increase in the heating rate, whereas the yield of the solid residue decreased. Zhang et al. [72,90] performed liquefaction of corn stover, aspen wood and high diversity grassland perennials and found that heating rate was a major parameter affecting the yield of liquid products, although there was no significant effect on the composition of liquid products. Corn stover and aspen wood were heated to $350{ }^{\circ} \mathrm{C}(20 \mathrm{MPa})$ at a rate of $5-140{ }^{\circ} \mathrm{C} \mathrm{min}{ }^{-1}$, whereas grassland perennials were heated to $375^{\circ} \mathrm{C}(22 \mathrm{MPa})$ at the same rate. It was found that the liquid yield increased for corn stover and aspen wood by approximately $20 \mathrm{wt} \%$ and for grassland perennials by $12 \mathrm{wt} \%$ when the heating rate increased. The cooling rate shows no significant effect on product yield. 
Table 5. Effect of retention time on HTL operation.

\begin{tabular}{|c|c|c|c|c|c|c|c|c|}
\hline Feedstock & $\begin{array}{l}\text { Process } \\
\text { Condition }\end{array}$ & $\begin{array}{c}\text { Product } \\
\text { Yield wt\%, }\end{array}$ & $\begin{array}{c}\mathrm{HHV}^{*} \\
\left(\mathrm{MJ} \mathrm{kg}^{-1}\right)\end{array}$ & $\underset{(w t \%)}{C^{*}}$ & $\underset{\left(w_{t} \%\right)}{H^{*}}$ & $\underset{(w t \%)}{O^{*}}$ & Comments/Findings & Ref. \\
\hline $\begin{array}{l}\text { Wood } \\
\text { (konara) }\end{array}$ & $\begin{array}{c}\mathrm{R}_{\mathrm{t}}^{*}: \\
0-180 \min \\
\mathrm{T}^{*}: 350{ }^{\circ} \mathrm{C} \\
\mathrm{P}_{\mathrm{i}}: 2 \mathrm{MPa}\end{array}$ & $\begin{array}{c}\mathrm{HO}^{*}: \\
14.7-24.6\end{array}$ & $30.3-35.8$ & $71.6-77.9$ & $6.9-7.9$ & $14.1-21.5$ & $\begin{array}{l}\text { Highest oil yield was obtained at } 0 \mathrm{~min} \\
\text { and yield decreased afterwards. }\end{array}$ & [88] \\
\hline $\begin{array}{l}\text { Cunninghamia } \\
\text { lanceolata }\end{array}$ & $\begin{array}{l}\mathrm{R}_{\mathrm{t}}: 10-30 \mathrm{~min} \\
\quad \mathrm{~T}: 320^{\circ} \mathrm{C}\end{array}$ & $\begin{array}{l}\text { HO: } \\
17.5-23.8\end{array}$ & 28.9 & 73.3 & 5.6 & 21.1 & $\begin{array}{l}\text { Optimum time was } 10 \text { min and the } \\
\text { CHNS and HHV values are mentioned for } \\
\text { the same. } \\
\text { The yield of oil decreased with } \\
\text { retention time. }\end{array}$ & [89] \\
\hline Birch powder & $\begin{array}{l}\mathrm{R}_{\mathrm{t}}: \\
10-480 \mathrm{~min} \\
\mathrm{~T}: 300{ }^{\circ} \mathrm{C} \\
\text { methanol }\end{array}$ & HO: 10-26 & - & - & - & - & $\begin{array}{l}\text { Total conversion and yield of all } \\
\text { products increased monotonically with } \\
\text { retention time. }\end{array}$ & [97] \\
\hline \multirow{2}{*}{$\begin{array}{l}\text { Microalgae } \\
\text { (Desmod- } \\
\text { esmus } \\
\text { sp.) }\end{array}$} & $\begin{array}{l}\mathrm{R}_{\mathrm{t}}: 5-60 \mathrm{~min} \\
\mathrm{~T}: 200^{\circ} \mathrm{C}\end{array}$ & $\mathrm{BO}^{*}: 10-23$ & $31.0-33.7$ & $66.6-69.2$ & $8.6-9.6$ & $17.5-22.8$ & \multirow{2}{*}{$\begin{array}{c}\text { The effect of retention time was more } \\
\text { pronounced at lower temperature } \\
\left(200^{\circ} \mathrm{C}\right) \text {. The effect of time was little at } \\
300^{\circ} \mathrm{C} \text { and above. } \\
\text { Water-soluble organics decreased with } \\
\text { reaction time above } 300^{\circ} \mathrm{C} \text {. }\end{array}$} & \multirow[b]{2}{*}{ [73] } \\
\hline & $\begin{array}{l}\mathrm{R}_{\mathrm{t}}: 5-60 \mathrm{~min} \\
\quad \mathrm{~T}: 300^{\circ} \mathrm{C}\end{array}$ & $\begin{array}{c}\text { BO: } \\
40.5-46.6\end{array}$ & $34.9-35.8$ & $72.4-75$ & $8.8-9$ & $10.2-12.3$ & & \\
\hline $\begin{array}{l}\text { Spirulina } \\
\text { platensis }\end{array}$ & $\begin{array}{c}\mathrm{R}_{\mathrm{t}}: 0-120 \mathrm{~min} \\
350^{\circ} \mathrm{C}, \\
20 \% \text { solid } \\
\text { concentration }\end{array}$ & $\begin{array}{c}\mathrm{BC}^{*}: \\
30-39.9\end{array}$ & $34.1-36.8$ & $73.1-77.2$ & $8.6-9.6$ & $9.1-11.1$ & $\begin{array}{c}\text { The yield of bio-crude increased from } \\
0 \text { min to } 60 \text { min and decreased } \\
\text { afterwards. WSO fraction decreased with } \\
\text { increase in time. } \\
\text { There was no significant effect on } \\
\text { solid residue. }\end{array}$ & [74] \\
\hline \multirow{2}{*}{$\begin{array}{l}\text { Cornelian } \\
\text { cherry stones }\end{array}$} & \multirow{2}{*}{$\begin{array}{l}\mathrm{R}_{\mathrm{t}}: 0-30 \mathrm{~min} \\
\quad \mathrm{~T}: 300^{\circ} \mathrm{C}\end{array}$} & $\mathrm{LO}^{*}: \sim 4-6$ & $22.5-23.9$ & $59.9-61.3$ & $5.8-6.3$ & $32.2-34$ & \multirow{2}{*}{$\begin{array}{l}\text { The total bio-oil yield was maximum at } \\
0 \text { min retention time for } 250^{\circ} \mathrm{C} \text { and } \\
300{ }^{\circ} \mathrm{C} \text {, whereas at lower temperature of } \\
200^{\circ} \mathrm{C} \text { it was maximum at } 30 \text { min. }\end{array}$} & \multirow[b]{2}{*}{ [76] } \\
\hline & & $\mathrm{HO}: ~ 14-22$ & $25.6-28.4$ & $59.2-67.2$ & $7.1-7.9$ & $25.1-32.3$ & & \\
\hline $\begin{array}{l}\text { Litsea cubeba } \\
\text { seed }\end{array}$ & $\begin{array}{l}\mathrm{R}_{\mathrm{t}}: \\
\text { 30-120 min } \\
\mathrm{T}: 290{ }^{\circ} \mathrm{C}\end{array}$ & $\begin{array}{c}\text { BO: } \\
53.5-56.9\end{array}$ & - & - & - & - & $\begin{array}{l}\text { It was observed that retention time had } \\
\text { limited effect on the product yield making } \\
\text { it a thermally controlled process. }\end{array}$ & [57] \\
\hline $\begin{array}{l}\text { Spent coffee } \\
\text { grounds }\end{array}$ & $\begin{array}{l}\mathrm{R}_{\mathrm{t}}: 5-30 \mathrm{~min} \\
\mathrm{~T}: 275^{\circ} \mathrm{C}, \mathrm{P}_{\mathrm{i}}: \\
\quad 2 \mathrm{MPa}\end{array}$ & $\begin{array}{l}\text { BC: } \\
22.7-31.7\end{array}$ & 31 & 71.2 & 7.1 & 18.7 & $\begin{array}{l}\text { The highest yield of crude bio-oil was } \\
\text { obtained at } 10 \mathrm{~min}(31.7 \mathrm{wt} \%) \text { followed by } \\
\text { a decrease until } 30 \mathrm{~min}(22.7 \mathrm{wt} \%) \text {. }\end{array}$ & [79] \\
\hline $\begin{array}{l}\text { Blackcurrant } \\
\text { pomace }\end{array}$ & $\begin{array}{l}\mathrm{R}_{\mathrm{t}}: 0-240 \mathrm{~min} \\
\quad \mathrm{~T}: 300^{\circ} \mathrm{C}\end{array}$ & BO: $22.5-27$ & 35.9 & 73.3 & 9.6 & 13.6 & $\begin{array}{c}\text { The CHNS and HHV value was provided } \\
\text { at } 300^{\circ} \mathrm{C} \text { and } 60 \text { min. The holding time } \\
\text { had no significant effect on the yield } \\
\text { of products. }\end{array}$ & [81] \\
\hline $\begin{array}{l}\text { Waste } \\
\text { furniture } \\
\text { sawdust }\end{array}$ & $\begin{array}{l}\mathrm{R}_{\mathrm{t}}: 0-60 \mathrm{~min} \\
\quad \mathrm{~T}: 280^{\circ} \mathrm{C}\end{array}$ & $\begin{array}{c}\text { BO: } \\
7.2-12.7\end{array}$ & - & - & - & - & $\begin{array}{l}\text { The maximum bio-oil yield was obtained } \\
\text { at residence time of } 15 \text { min. } \\
\text { The yield of solid residue decreased } \\
\text { initially until } 30 \text { min and increased } \\
\text { thereafter, whereas the gas yield increased } \\
\text { with increase in retention time. }\end{array}$ & {$[38]$} \\
\hline $\begin{array}{l}\text { Empty fruit } \\
\text { bunch }\end{array}$ & $\begin{array}{l}\mathrm{R}_{\mathrm{t}}: \\
15-120 \mathrm{~min} \\
\mathrm{~T}: 360-450{ }^{\circ} \mathrm{C} \\
\mathrm{P}: 25 \mathrm{MPa}\end{array}$ & - & - & - & - & - & $\begin{array}{l}\text { The relative yield of bio-oil increased } \\
\text { throughout retention time for T: } 360^{\circ} \mathrm{C} \text {. } \\
\text { The relative yield of bio-oil increased until } \\
60 \text { min for temperatures } 390 \text { and } 450{ }^{\circ} \mathrm{C} \text {, } \\
\text { and decreased steeply on further increase } \\
\text { in time. }\end{array}$ & [103] \\
\hline $\begin{array}{l}\text { Olive oil } \\
\text { residue }\end{array}$ & $\begin{array}{l}\mathrm{R}_{\mathrm{t}}: 5-60 \mathrm{~min} \\
\mathrm{~T}: 300^{\circ} \mathrm{C}\end{array}$ & $\begin{array}{c}\text { BO: } \\
20.7-30.8\end{array}$ & $29.1-32.2$ & $68.0-70.7$ & $7.3-8.3$ & $20-23.7$ & $\begin{array}{l}\text { The yield of bio-oil and solid residue } \\
\text { increased from } 5 \text { to } 15 \text { min and decreased } \\
\text { afterwards. The carbon percentage and } \\
\text { HHV value of bio-oil was maximum at } \\
\text { residence time of } 5 \text { min. }\end{array}$ & [85] \\
\hline
\end{tabular}

* HO: heavy oil, BO: bio-oil, BC: bio-crude, LO: light oil, HHV; higher heating value, C: carbon, H: hydrogen, O: oxygen; T: temperature, Rt: retention time. 
Table 6. Effect of heating rate in HTL process.

\begin{tabular}{|c|c|c|c|c|c|}
\hline Type & Feedstock & $\begin{array}{l}\text { Process } \\
\text { Condition }\end{array}$ & $\begin{array}{l}\text { Product } \\
\text { Yield wt } \%\end{array}$ & Comments/Findings & Ref. \\
\hline \multirow{6}{*}{ Wood } & Corn stover & \multirow{3}{*}{$\begin{array}{c}5-140 \\
{ }^{\circ} \mathrm{C} \min ^{-1} \\
\mathrm{~T}^{*}: 350^{\circ} \mathrm{C}\end{array}$} & LP *: & $\begin{array}{c}\text { Liquid yield (\%) } \\
-(0051 \times \ln (\text { Heating rate) }\end{array}$ & \multirow{3}{*}[72]{} \\
\hline & & & $53.4-70.6$ & $=(0.051 \times \ln ($ Heating rate $)+0.4532) \times 100$ & \\
\hline & Aspen wood & & $\begin{array}{c}\text { LP: } \\
50.3-72.4\end{array}$ & $\begin{array}{c}\text { Liquid yield }(\%) \\
=(0.0627 \times \ln (\text { Heating rate })+0.4239) \times 100\end{array}$ & \\
\hline & $\begin{array}{l}\text { High diversity } \\
\text { grassland } \\
\text { perennials }\end{array}$ & $\begin{array}{l}5-140 \\
{ }^{\circ} \mathrm{C} \min ^{-1} \\
\mathrm{~T}: 375^{\circ} \mathrm{C}\end{array}$ & $\begin{array}{l}\text { LP: } \\
61.1-73.1\end{array}$ & $\begin{array}{c}\text { Liquid yield }(\%) \\
=(0.0042 \times \ln (\text { Heating rate })+0.5514) \times 100\end{array}$ & [90] \\
\hline & $\begin{array}{l}\text { Red pine } \\
\text { sawdust }\end{array}$ & $\begin{array}{l}3-20 \\
{ }^{\circ} \mathrm{C} \min ^{-1} \\
\mathrm{~T}: 350{ }^{\circ} \mathrm{C}\end{array}$ & $\begin{array}{l}\mathrm{BC} * \\
15-27\end{array}$ & $\begin{array}{l}\text { Maximum bio-crude was obtained by a combination of fast } \\
\text { heating rate, high final temperature, and immediate } \\
\text { quenching.There was no effect of heating rate in the } \\
\text { presence of supercritical EtOH. }\end{array}$ & {$[58]$} \\
\hline & Spruce wood & $\begin{array}{l}66-179 \\
{ }^{\circ} \mathrm{C} \min ^{-1} \\
\mathrm{~T}: 350^{\circ} \mathrm{C}\end{array}$ & $\begin{array}{c}\mathrm{BO} *: \\
18.9-35.8\end{array}$ & $\begin{array}{l}\text { The bio-oil yield increases with increasing heating rate, } \\
\text { whereas the solid residue decreases. } \\
\text { Maximum yield was obtained at heating rate of } \\
179^{\circ} \mathrm{C} \mathrm{m_{n } ^ { - 1 }} .\end{array}$ & [104] \\
\hline \multirow{3}{*}{ Algae } & $\begin{array}{l}\text { Laminaria } \\
\text { saccharina }\end{array}$ & $\begin{array}{l}146-585 \\
{ }^{\circ} \mathrm{C} \min ^{-1} \\
\mathrm{~T}: 350^{\circ} \mathrm{C}\end{array}$ & $\begin{array}{l}\text { BO: } \\
53-79\end{array}$ & $\begin{array}{l}\text { Fast heating rate promoted bio-oil yield and decreased } \\
\text { formation of gas and char. }\end{array}$ & [105] \\
\hline & Chlorella & \multirow{2}{*}{$\begin{array}{l}10-25 \\
{ }^{\circ} \mathrm{C} \min ^{-1} \\
\mathrm{~T}: 350{ }^{\circ} \mathrm{C}\end{array}$} & $\begin{array}{l}\text { BO: } \\
35.8\end{array}$ & \multirow{2}{*}{$\begin{array}{l}\text { There was no significant effect of heating rate on the yield } \\
\text { of bio-oil. }\end{array}$} & \multirow{2}{*}[106,107]{} \\
\hline & Nannochloropsis & & $\begin{array}{l}\text { BO: } \\
34.3\end{array}$ & & \\
\hline
\end{tabular}

* BO: bio-oil, BC: bio-crude, LP: liquid products, T: temperature.

Brand et al. [58] performed a detailed experimental study to understand the effect of the heating rate $\left(2-20^{\circ} \mathrm{C} \mathrm{min}^{-1}\right)$ on liquefaction of sawdust for a temperature range of $250-350{ }^{\circ} \mathrm{C}$ in the presence of $\mathrm{H}_{2} \mathrm{O}$ and $\mathrm{EtOH}$ as solvents. It was observed that in the presence of $\mathrm{H}_{2} \mathrm{O}$ solvent and for a final temperature of $250^{\circ} \mathrm{C}$, yield of bio-crude was more at a heating rate of $2{ }^{\circ} \mathrm{C} \min ^{-1}(8 \mathrm{wt} \%)$ than that at $20^{\circ} \mathrm{C} \min ^{-1}(5 \mathrm{wt} \%)$. At a higher temperature of $350{ }^{\circ} \mathrm{C}$, the bio-crude yield at $2{ }^{\circ} \mathrm{C} \mathrm{min}^{-1}(15 \mathrm{wt} \%)$ was significantly lower than that at $20^{\circ} \mathrm{C} \mathrm{min}^{-1}(27 \mathrm{wt} \%)$. It suggests that the optimum heating rate is linked to the operation temperature. For a final temperature of $250{ }^{\circ} \mathrm{C}$, when compared to a fast-heating rate, a slow heating rate provides more time for the solvent to interact with the lignocellulose, yielding a slightly higher conversion and more bio-crude. Furthermore, for a higher temperature of 280 to $350^{\circ} \mathrm{C}$, the conversion and bio-crude yield remained mostly unchanged with the heating rate, which could be because of the simultaneous hydrolysis of biomass and the repolymerization of intermediates at high temperatures. The effect of the heating rate in the presence of $\mathrm{EtOH}$ was negligible; a plausible explanation may be that the supercritical state of $\mathrm{EtOH}$ in the temperature range had a stronger effect than the heating rate.

Heating rate is a prominent factor, which needs to be accounted for, along with the operation temperature and retention time. A slow heating rate may be better for a lower subcritical temperature operation, whereas a fast-heating rate may be better for higher subcritical and supercritical temperature operations. In the case of high temperature operations, a slow heating rate may end up promoting many secondary reactions, such as the repolymerization/carbonization of intermediates and bio-oil fractions to char, whereas processes with significantly high heating rates can prompt secondary cracking of long chain hydrocarbons and aromatics, resulting in the formation of gaseous products. In general, the optimum temperature range for HTL lies between 300 and $350{ }^{\circ} \mathrm{C}$; a moderate-to-fast heating rate suitably increases the kinetics for hydrolysis, dehydration, and fragmentation 
and limits radicalization and repolymerization in the given temperature range. The current literature does little to enhance our understanding of how heating rates affect lignocellulosic biomass HTL, bio-oil yield, and reaction mechanisms. More intensive and detailed studies are needed.

\subsection{Biomass-to-Solvent Ratio}

The term biomass-to-solvent ratio is also known as feed ratio. As the majority of the experiments are conducted using water, feed ratio is more commonly known as biomass-to-water ratio. Some studies have defined it in a reciprocal form and called it the water/solvent-to-biomass ratio [38,79]. For the HTL of lignocellulosic biomass in a batch process, it is logical to define the feed ratio as the biomass-to-water ratio, whereas in continuous processes where a pretreated concentrated slurry is supplied to the processing system, it is more commonly referred to as a solid concentration ( $w \mathrm{t} \%$ or mass fraction) or reactor loading.

Feed ratio is an important parameter and needs to be controlled in a certain desired range to obtain a higher conversion and maximize bio-oil yield. Water is essential for solvolysis, to act as a solvent medium. In cases where the biomass-to-water ratio is very low, the yield will be low as the carbon entering the system will be low, whereas the cost of operation (heating) will be high because of the need to raise the water temperature to the desired level. For the biomass-to-water ratio where the solid concentration is very high, not enough $\mathrm{H}^{+}$and $\mathrm{OH}^{-}$ions will be available to support the hydrolysis of the lignocellulosic biomass. Furthermore, the high solid concentration directly impacts the cost of the process because of the need for intense pumping, a better mixing and turbulence facility, and improved heating supply. Higher solid loading increases the bio-oil yield and reduces carbon losses in the system [10].

Some of the research focused on feed ratio is discussed in Table 7. Akhtar et al. [108] performed liquefaction of an empty palm fruit bunch at $270{ }^{\circ} \mathrm{C}$ and $1.0 \mathrm{M} \mathrm{K}_{2} \mathrm{CO}_{3}$ for a feed ratio (biomass-to-water) of $1 / 10-8 / 10 \mathrm{~g} \mathrm{~mL}^{-1}$; the study suggested that increasing the feed ratio from $1 / 10$ to $2 / 10 \mathrm{~g} \mathrm{~mL}^{-1}$ increased the conversion and liquid yield. A further increase of the feed concentration drastically decreased the biomass conversion and product yield. In many other studies, it was observed that, after a point with the increase in the concentration of biomass, there was a decrease in the yield of bio-oil $[57,81,89]$. The low concentration of aqueous solvent in cases of high feed concentration makes it difficult for a solvent to dissolve the biomass. The low degradation of biomass due to the solvent's poor dissolution power leads to a decrease in conversion and yield. In highly concentrated feed, unconverted biomass must compete with other intermediate hydrolysis reactions for water, leading to an increased intermediate concentration in the aqueous phase and bio-oil. This increased intermediate concentration results in a higher probability of repolymerization reactions, leading to a higher solid residue formation [81]. Moreover, a very high solid amount, with respect to the available water, can limit the availability of water for solvolysis and the hydration process, resulting in poor and incomplete degradation of the lignocellulosic biomass, leaving behind unconverted solid residue [96]. Wang et al. [57] performed HTL of Litsea cubeba seed powder at different reactor loading concentrations and observed that, with an increase in the reactor loading from 0.5 to $4.5 \mathrm{~g}$, the yield of the gases decreased from $40 \%$ to $19.6 \%$. The decrease in the gas fraction was linked to the high-pressure build-up in the reactor caused by higher reactor loading. 
Table 7. Effect of the feed ratio in HTL process.

\begin{tabular}{|c|c|c|c|c|c|c|c|c|}
\hline Feedstock & $\begin{array}{l}\text { Process } \\
\text { Condition }\end{array}$ & $\begin{array}{c}\text { Product } \\
\text { Yield (wt } \%)\end{array}$ & $\begin{array}{c}\text { HHV } \\
\left(\mathrm{MJ} \mathrm{kg}^{-1}\right)\end{array}$ & $\begin{array}{c}C^{*} \\
\left(w t^{\circ} \%\right)\end{array}$ & $\begin{array}{c}\mathrm{H}^{*} \\
(\mathbf{w t} \%)\end{array}$ & $\underset{(w t \%)}{O *}$ & Comments & Ref. \\
\hline $\begin{array}{l}\text { Wood } \\
\text { (konara) }\end{array}$ & $\begin{array}{c}1 / 16-1 / 6 \\
\mathrm{~g} / \mathrm{mL} \\
\mathrm{T}^{*}: 300^{\circ} \mathrm{C} \\
\mathrm{P}_{\mathrm{i}} *: 2 \mathrm{MPa} \\
\mathrm{R}_{\mathrm{t}}^{*}: 30 \mathrm{~min}\end{array}$ & $\begin{array}{c}\mathrm{HO} *: \\
16.4-25.2\end{array}$ & 31.9-33.8 & $73.8-76.6$ & $7.16-7.48$ & 15.9-19 & $\begin{array}{c}\text { Yield of oil was maximum } \\
\text { at } 5 / 50 \mathrm{~g} / \mathrm{mL} \text { of } \\
\text { biomass / water ratio. }\end{array}$ & [88] \\
\hline $\begin{array}{l}\text { Cunninghamia } \\
\text { lanceolata }\end{array}$ & $\begin{array}{c}\text { 8/100- } \\
12.5 / 100 \\
\text { g/mLT: } \\
320^{\circ} \mathrm{C} \\
\mathrm{R}_{\mathrm{t}}: 10 \mathrm{~min}\end{array}$ & $\begin{array}{l}\text { HO: } \\
\text { 16.3-23.8 }\end{array}$ & - & - & - & - & $\begin{array}{l}\text { The fraction of heavy oil } \\
\text { decreased with increasing } \\
\text { biomass / water ratio. }\end{array}$ & [89] \\
\hline $\begin{array}{l}\text { Secondary } \\
\text { pulp/paper } \\
\text { sludge }+ \\
\text { newspaper }\end{array}$ & $\begin{array}{c}4.8-16.7 \mathrm{wt} \% \\
\text { solid } \\
\text { concentration } \\
\mathrm{T}: 280^{\circ} \mathrm{C} \\
\mathrm{R}_{\mathrm{t}}: 60 \mathrm{~min}\end{array}$ & $\begin{array}{l}\mathrm{HO}: \\
15-22\end{array}$ & - & - & - & - & $\begin{array}{l}\text { There was a significant } \\
\text { decrease in water-soluble } \\
\text { organics with increased } \\
\text { feed concentration. }\end{array}$ & [96] \\
\hline $\begin{array}{l}\text { Empty palm } \\
\text { fruit bunch }\end{array}$ & $\begin{array}{c}1 / 10-8 / 10 \\
\mathrm{~g} / \mathrm{mL} \\
\mathrm{T}: 270{ }^{\circ} \mathrm{C}, \\
\mathrm{P}_{\mathrm{i}}: 2 \mathrm{MPa}, \\
\mathrm{R}_{\mathrm{t}}: 20 \mathrm{~min}\end{array}$ & $\begin{array}{l}\mathrm{LP} *: \\
50-68\end{array}$ & - & - & - & - & $\begin{array}{c}\text { Phenols (0.6-60.0), methyl } \\
\text { ester (0-94.3\%), benzoic } \\
\text { acid }(0-24.3 \%) \\
\text { With increase in feed } \\
\text { concentration fraction of } \\
\text { methyl esters decreased } \\
\text { initially and on further } \\
\text { increase vanished } \\
\text { completely. }\end{array}$ & [108] \\
\hline $\begin{array}{l}\text { Spirulina } \\
\text { platensis }\end{array}$ & $\begin{array}{c}10-50 \% \text { solid } \\
\text { concentration } \\
350{ }^{\circ} \mathrm{C} \\
\mathrm{R}_{\mathrm{t}}: 60 \mathrm{~min}\end{array}$ & $\begin{array}{c}\mathrm{BC}^{*}: \\
33-39.9\end{array}$ & $35.6-35.9$ & $72.3-73.8$ & 8.9-9.1 & $10.5-11.7$ & $\begin{array}{l}\text { Bio-crude yield increased } \\
\text { as solid concentration } \\
\text { increased from } 10 \text { to } 20 \% \text {. } \\
\text { No change in product } \\
\text { composition over solid } \\
\text { concentration of } 20 \% \text {. }\end{array}$ & {$[74]$} \\
\hline $\begin{array}{l}\text { Litsea cubeba } \\
\text { seed powder }\end{array}$ & $\begin{array}{l}0.5-4.5 \mathrm{~g} \\
\mathrm{~T}: 290^{\circ} \mathrm{C} \\
\mathrm{R}_{\mathrm{t}}: 60 \mathrm{~min}\end{array}$ & $\begin{array}{c}\mathrm{BO} *: \\
42.4-56.9\end{array}$ & 40.8 & 76.2 & 11.9 & 10.4 & $\begin{array}{l}\text { The bio-oil yield increased } \\
\text { initially with solid fraction } \\
\text { and started to decrease } \\
\text { afterwards. }\end{array}$ & [57] \\
\hline Miscanthus & $\begin{array}{l}2 / 5-1 / 15 \\
\mathrm{~T}: 410{ }^{\circ} \mathrm{C}, \mathrm{R}_{\mathrm{t}}: \\
\quad 60 \mathrm{~min}\end{array}$ & $\begin{array}{l}\mathrm{HO}: \\
9-22\end{array}$ & - & 77 & 6.9 & 16 & - & [78] \\
\hline $\begin{array}{l}\text { Spent coffee } \\
\text { grounds }\end{array}$ & $\begin{array}{c}1 / 20-1 / 5 \\
\mathrm{~g} / \mathrm{mL} \\
\mathrm{T}: 275^{\circ} \mathrm{C} \\
\mathrm{P}_{\mathrm{i}}: 2 \mathrm{MPa} \\
\mathrm{R}_{\mathrm{t}}: 10 \mathrm{~min}\end{array}$ & $\begin{array}{c}\text { BC: } \\
35.3-47.3\end{array}$ & 31 & 71.2 & 7.1 & 18.7 & $\begin{array}{l}\text { Larger water to spent coffee } \\
\text { ground ratio has positive } \\
\text { impact on conversion rate } \\
\text { and bio-oil yield. }\end{array}$ & [79] \\
\hline $\begin{array}{c}\text { Blackcurrant } \\
\text { pomace }\end{array}$ & $\begin{array}{c}0.05-0.29 \text { (dry } \\
\text { mass fraction) } \\
\mathrm{T}: 300^{\circ} \mathrm{C} \\
\mathrm{R}_{\mathrm{t}}: 60 \mathrm{~min}\end{array}$ & $\begin{array}{c}\text { BO: } \\
24-29\end{array}$ & - & - & - & - & $\begin{array}{l}\text { Carbon recovery in bio-oil } \\
\text { increased initially with } \\
\text { increase in concentration } \\
\text { and decreased after a point, } \\
\text { whereas the yield of bio-oil } \\
\text { decreased thoroughly. }\end{array}$ & [81] \\
\hline
\end{tabular}

* HO: heavy oil, BO: bio-oil, BC: bio-crude, LP: liquid products, $\mathrm{HHV}$; higher heating value, C: carbon, $\mathrm{H}$ : hydrogen, O: oxygen; $\mathrm{P}_{\mathrm{i}}$ : initial pressure, $\mathrm{P}_{\mathrm{f}}$ : final pressure, $\mathrm{T}$ : temperature, $\mathrm{R}_{\mathrm{t}}$ : retention time.

\section{Effect of Catalysts and Solvents}

\subsection{Effect of Catalysts}

Over the last two decades, many researchers have focused on the effect of catalysts, as summarized in Table 8. The effects of different catalysts on the overall product yield, quality, and biomass decomposition are provided in Table 9. In most of the cases, the catalyst plays a promising role in increasing the bio-oil yield and improving its properties. It also triggers earlier and faster biomass degradation and hinders secondary reactions, such as repolymerization and cracking, activating kinetics of reactions and reducing dependency on pressure, temperature, and retention time. The two classes of catalysts used in the HTL operation are homogeneous and heterogeneous. These classes are discussed in detail in the following sections. 
Table 8. Some major HTL studies focused on understanding the effect of catalysts.

\begin{tabular}{|c|c|c|c|c|}
\hline S. No & Year & Description/Objective & Results/Observations/Major Findings & Ref. \\
\hline 1 & 2005 & $\begin{array}{l}\text { Low temperature catalytic hydrothermal } \\
\text { treatment of wood biomass: analysis of } \\
\text { liquid products. } \\
\text { Effect of } \mathrm{Na} \text { and K hydroxides and } \\
\text { carbonates on liquefaction products. }\end{array}$ & $\begin{array}{c}\text { Catalytic activity order } \mathrm{K}_{2} \mathrm{CO}_{3}>\mathrm{KOH}>\mathrm{RbCO}_{3} \\
>\mathrm{RbOH}>\mathrm{Na}_{2} \mathrm{CO}_{3}>\mathrm{NaOH}>\mathrm{CsCO}_{3}>\mathrm{CsOH} \text { for } \\
\text { bio-oil production. } \\
\text { Oil yield increased from } 8.6 \mathrm{wt} \% \text { in water to } \\
\quad 33.7 \mathrm{wt} \% \text { in the presence of } \mathrm{K}_{2} \mathrm{CO}_{3} . \\
\text { Boiling point of hydrocarbons ranged near } \mathrm{n}-\mathrm{C}_{11} \\
\text { and mainly phenolic in nature. }\end{array}$ & {$[70,109,110]$} \\
\hline 2 & 2010 & $\begin{array}{l}\text { Direct liquefaction of paulownia in hot } \\
\text { compressed water. } \\
\text { Effect of } \mathrm{Fe} \text { and } \mathrm{Na}_{2} \mathrm{CO}_{3} \text { on heavy } \\
\text { oil yield. }\end{array}$ & $\begin{array}{l}\text { Both } \mathrm{Fe} \text { and } \mathrm{Na}_{2} \mathrm{CO}_{3} \text { effectively enhanced the } \\
\text { formation of heavy oil, and the highest heavy oil } \\
\text { yield of } 36.34 \mathrm{wt} \% \text { was observed with Fe catalyst } \\
\text { at } 340{ }^{\circ} \mathrm{C} \text {. } \\
\text { Both catalysts significantly promoted the } \\
\text { gases formation. }\end{array}$ & [41] \\
\hline 3 & 2012 & $\begin{array}{l}\text { HTL of beech wood using a natural } \\
\text { calcium borate mineral. }\end{array}$ & $\begin{array}{c}\text { The total bio-oil yield at } 300{ }^{\circ} \mathrm{C}, 0 \mathrm{~min} \text { without } \\
\text { and with colemanite was } 21 \mathrm{wt} \% \text { and } 41 \mathrm{wt} \% \text {. } \\
\text { The use of colemanite had no significant effect on } \\
\text { heating value and composition of oil. }\end{array}$ & [43] \\
\hline 4 & 2013 & $\begin{array}{l}\text { Effect of sodium perborate monohydrate } \\
\text { concentrations on product distributions } \\
\text { from HTL of scotch pine wood. }\end{array}$ & $\begin{array}{l}\text { The highest heating value of resulting heavy oil } \\
\text { was } 32 \mathrm{MJ} \mathrm{kg}-1 \text {, at } 350^{\circ} \mathrm{C} \text { with the catalyst. } \\
\text { The product distribution significantly varied with } \\
\text { temperature and additive concentration. }\end{array}$ & [111] \\
\hline 5 & 2015 & $\begin{array}{l}\text { Influence of alkali catalyst on product } \\
\text { yield and properties via HTL of } \\
\text { barley straw. }\end{array}$ & $\begin{array}{l}\text { Addition of } \mathrm{K}_{2} \mathrm{CO}_{3} \text { increased bio-crude yield and } \\
\text { inhibited solid char formation. } \\
\text { Catalyst run bio-crude has better properties, such } \\
\text { as higher } \mathrm{HHV} \text { value and lower } \mathrm{O} / \mathrm{C} \text { ratio. }\end{array}$ & [15] \\
\hline 6 & 2016 & $\begin{array}{l}\text { Characterization of HTL products from } \\
\text { coconut shell in the presence of selected } \\
\text { transition metal chlorides. } \\
\text { To examine the effect of } \mathrm{Zn}, \mathrm{Cu} \text { and Ni on } \\
\text { HTL at fixed temperature and to } \\
\text { understand the effect of temperature. }\end{array}$ & $\begin{array}{l}\text { The highest bio-oil yield was } 13.9 \mathrm{wt} \% \text { at } 300{ }^{\circ} \mathrm{C} \\
\text { without the catalyst, where the water content was } \\
\text { minimum ( } 3 \mathrm{wt} \%) \text { and } \mathrm{HHV} \text { was highest } \\
\left(31.1 \mathrm{MJ} \mathrm{kg}^{-1}\right) \text {. } \\
\text { Main decomposition products of cellulose } \\
\text { levulinic acid and } \gamma \text {-valerolactone were present } \\
\text { in oil.The use of transition metals helped in } \\
\text { decreasing the TAN value of oil. }\end{array}$ & [93] \\
\hline 7 & 2016 & $\begin{array}{l}\text { Structural analysis of bio-oil from } \\
\text { subcritical and supercritical HTL of } \\
\text { Datura stramonium L. plant stems. } \\
\text { Understanding the effect of temperature } \\
\text { and catalyst (colemanite and borax). }\end{array}$ & $\begin{array}{c}\text { Conversion increased with increase in } \\
\text { temperature. Colemanite catalyst was more } \\
\text { effective than Borax. } \\
\text { The GC-MS composition at all of the } \\
\text { temperatures were provided. }\end{array}$ & [36] \\
\hline
\end{tabular}

The use of water tolerant Lewis acids had negative effects on bio-oil yields.

$8 \quad 2016 \quad$ The effects of water tolerant Lewis acids on the HTL of lignocellulosic biomass.
The study suggest that low catalyst concentration promotes production of oil.

Lewis acids have no significant effects on composition of oil.

Production of bio-oil via HTL of birch sawdust.

To understand the effect of

92017 biomass / water ratio, temperature, $\mathrm{H}_{2}$ pressure, residence time, catalysts $\left(\mathrm{FeSO}_{4}\right.$,

$\mathrm{ZnSO}_{4}, \mathrm{NiSO}_{4}$, Raney nickel, Ni65\% $\left.-\mathrm{Al}_{2} \mathrm{O}_{3}, \mathrm{Na}_{2} \mathrm{CO}_{3}, \mathrm{NaOH}\right)$.

HTL of rice straw with $\mathrm{NiO}$ nanocatalyst for bio-oil production.
The highest yield of bio-oil ( $54.1 \mathrm{wt} \%$ ) was obtained at $300^{\circ} \mathrm{C}, 5 \mathrm{~min}$ in the presence of $\mathrm{NaOH}$ catalyst.

The order of catalyst to promote bio-oil yield was

$\mathrm{NaOH}>\mathrm{Na}_{2} \mathrm{CO}_{3}>\mathrm{Ni65} \% \mid \mathrm{SiO}_{2}-\mathrm{Al}_{2} \mathrm{O}_{3}>$ Raney nickel $>\mathrm{NiSO}_{4}>\mathrm{ZnSO}_{4}>\mathrm{FeSO}_{4}>$ none.

The tested catalyst $(\mathrm{NiO})$ helped in increasing the overall oil yield but had no significant impact on the elemental composition and HHV of oil. 
Table 8. Cont.

\begin{tabular}{|c|c|c|c|c|}
\hline S. No & Year & Description/Objective & Results/Observations/Major Findings & Ref. \\
\hline 11 & 2017 & $\begin{array}{l}\text { Catalytic HTL for bio-oil production over } \\
\text { carbon nanotubes (CNTs) supported } \\
\text { metal catalysts. } \\
\text { Effect of carbon nanotubes supported } \\
\text { transition metals (Co, Ni, Pt) for HTL of } \\
\text { Dunaliella tertiolecta to produce bio-oil. }\end{array}$ & $\begin{array}{c}\text { The addition of catalysts was conducive for } \\
\text { bio-oil yield and quality. } \\
\text { All }(\mathrm{Co}, \mathrm{Ni} \text {, and } \mathrm{Pt}) \text { gave almost equal bio-oil } \\
\text { yield of } 40.25 \mathrm{wt} \% \text {, whereas the conversion of } \\
\text { biomass was highest for Co I CNTs }(95.8 \%)>\mathrm{Ni} \\
(93.3 \%)>\mathrm{Pt}(92.4 \%)>\text { None }(\sim 89 \%) \text {. } \\
\text { Bio-oil obtained using Co catalyst had higher } \\
\text { hydrocarbons, lower fatty acids, and } \\
\text { nitrogen compounds. } \\
\text { The selected catalysts helped in reducing the } \\
\text { nitrogen content in bio-oil. }\end{array}$ & [112] \\
\hline 12 & 2017 & $\begin{array}{l}\text { Bio-crude from pretreated sorghum } \\
\text { bagasse through catalytic HTL. } \\
\text { To study liquefaction at different } \\
\text { temperature and six different catalysts. }\end{array}$ & $\begin{array}{l}\text { The highest bio-crude yield was obtained with } \\
\qquad \mathrm{K}_{2} \mathrm{CO}_{3}(61.8 \mathrm{wt} \%) \text { catalyst. } \\
\text { The bio-crude had high carbon content and low } \\
\text { nitrogen and sulfur contents. } \\
\text { The relative high oxygen content } \sim 15 \% \text { in } \\
\text { bio-crude requires it to be upgraded before } \\
\text { refinery ready. }\end{array}$ & [29] \\
\hline 13 & 2017 & $\begin{array}{l}\text { Metal oxide catalyzed hydrothermal } \\
\text { liquefaction of Malaysian oil palm } \\
\text { biomass to bio-oil under } \\
\text { supercritical condition. } \\
\text { Effect of } \mathrm{CaO}, \mathrm{MgO}, \mathrm{MnO}, \mathrm{ZnO}, \mathrm{NiO}, \\
\mathrm{SnO}, \mathrm{CeO}_{2}, \mathrm{Al}_{2} \mathrm{O}_{3}, \mathrm{La}_{2} \mathrm{O}_{3} \text { was studied. } \\
\text { Fitting kinetic formation to the modified } \\
\text { Reverchon-Sesti Osseo model. }\end{array}$ & $\begin{array}{l}\text { It was found that } \mathrm{La}_{2} \mathrm{O}_{3}, \mathrm{CeO}_{2}, \mathrm{MnO} \text { and } \mathrm{CaO} \text {, } \\
\text { were four most active catalyst. } \\
\text { The bio-oil yield in case of } \mathrm{CeO}_{2} \text { was } 1.44 \text { times } \\
\text { that of without catalyst. } \\
\text { It was found that phenolics, ketones, other } \\
\text { aromatics, and carboxylic acids were the } \\
\text { major compounds. } \\
\text { The bio-oil produced was easily volatilized and } \\
\text { combusted in TGA study. }\end{array}$ & [103] \\
\hline 14 & 2019 & $\begin{array}{l}\text { Enhanced bio-crude yield and quality by } \\
\text { reductive HTL of oak wood biomass: } \\
\text { Effect of iron addition. } \\
\text { Iron powder, hematite, and magnetite } \\
\text { were investigated as catalyst in } 1: 5 \\
\text { biomass to water ratio for } 260-330^{\circ} \mathrm{C} \text {. }\end{array}$ & $\begin{array}{l}\text { Oxidation of Fe to produce } \mathrm{H}_{2} \text { in water was a key } \\
\text { step in the process as the produced } \mathrm{H}_{2} \text { prevented } \\
\text { the repolymerization and condensation of } \\
\text { bio-oil precursors. } \\
\text { Fe as catalyst increased the bio-oil yield by } \\
30 \mathrm{wt} \% \text { and improved the quality by reducing } \\
\text { oxygen content, increasing the HHV value to } \\
32.4 \mathrm{MJ} \mathrm{kg}^{-1} \text {. }\end{array}$ & {$[31]$} \\
\hline 15 & 2020 & $\begin{array}{l}\text { Catalytic HTL of lactuca scariola with a } \\
\text { heterogeneous catalyst. } \\
\text { Effect of } \mathrm{Zn}, \mathrm{Fe} \text {, and } \mathrm{Zn}+\text { Fe was studied. }\end{array}$ & $\begin{array}{l}\text { Fe was found to be most effective for the } \\
\text { production of bio-oil. } \\
\text { The yield of aqueous and gas fraction was } \\
\text { maximum in the presence of } \mathrm{Zn}+\text { Fe. }\end{array}$ & {$[84]$} \\
\hline 16 & 2021 & $\begin{array}{l}\text { HTL of olive oil residue } \\
\text { Understanding the effect of metal } \\
\text { chlorides on HTL products. }\end{array}$ & $\begin{array}{l}\text { It was found that the yield of bio-oil decreased } \\
\text { and that of solid residue increased with the } \\
\text { addition of } \mathrm{AlCl}_{3} \text { and } \mathrm{SnCl}_{3} \text {. }\end{array}$ & [85] \\
\hline 17 & 2021 & $\begin{array}{l}\text { Use of Lewis acid, a Brønsted acid, and } \\
\text { their binary mixtures for the HTL of } \\
\text { lignocellulose.HTL of teak wood was } \\
\text { studied without and with the use of } \\
\qquad \mathrm{Mg}\left(\mathrm{ClO}_{4}\right)_{2}, \mathrm{HClO}_{4} \text {, and } \\
\qquad \mathrm{HClO}_{4} / \mathrm{Mg}\left(\mathrm{ClO}_{4}\right)_{2} \text {. }\end{array}$ & $\begin{array}{l}\text { It was found that the catalyst had a negative } \\
\text { effect on the yield of bio-oil; moreover, the yield } \\
\text { of oil was found to decrease with the increase of } \\
\text { catalyst loading. } \\
\text { The use of catalyst increased the percentage of } \\
\text { naphtha in bio-oils. } \\
\text { The relative yield of ketones, phenols, and acids } \\
\text { were affected in the presence of the catalyst. }\end{array}$ & [113] \\
\hline
\end{tabular}

\subsubsection{Homogeneous Catalysts}

A wide range of homogeneous catalysts is used for the process of liquefaction. These include hydroxides and carbonate salts of alkali, such as $\mathrm{NaOH}, \mathrm{Na}_{2} \mathrm{CO}_{3}, \mathrm{KOH}$, and $\mathrm{K}_{2} \mathrm{CO}_{3}$, and many acids, such as hydrochloric acid, sulfuric acid, phosphoric acid, and 
acetic acid. Both the hydroxide and carbonates of alkali metals are found to greatly increase the degradation of biomass in a water medium, giving a higher liquid product yield. In a series of literature, a detailed analysis on the efficacy of alkali and alkaline earth metal salts in a water medium for liquefaction of lignocellulosic biomass was presented by Karagoz et al. $[69,105,106]$. The catalysts can be arranged according to their decreasing effect on the yield of total bio-oil: $\mathrm{K}_{2} \mathrm{CO}_{3}>\mathrm{KOH}>\mathrm{RbCO}_{3}>\mathrm{RbOH}>\mathrm{Na}_{2} \mathrm{CO}_{3}>\mathrm{NaOH}>\mathrm{CsCO}_{3}>$ $\mathrm{CsOH}>\mathrm{Ca}(\mathrm{OH})_{2}>$ none. In the case of $\mathrm{K}_{2} \mathrm{CO}_{3}$ as a catalyst, the total bio-oil yield increased from $8.6 \mathrm{wt} \%$ (thermal run) to $33.7 \mathrm{wt} \%$ and the solid residue decreased from $41.7 \mathrm{wt} \%$ (thermal) to $4.0 \mathrm{wt} \%\left(\mathrm{~K}_{2} \mathrm{CO}_{3}\right)$. Later the effect of alkali was considered by many other groups, $\mathrm{K}_{2} \mathrm{CO}_{3}$ [108], $\mathrm{Na}_{2} \mathrm{CO}_{3}$ [114], $\mathrm{NaOH}$ [115], $\mathrm{KOH}$ [116]. Tekin et al. [43] inspected the usefulness of potassium tert-butoxide $(\mathrm{t}-\mathrm{BuOK})$ and $\mathrm{KOH}$ on the liquefaction of scotch pine wood and found that the catalyst had a negligible effect at $250^{\circ} \mathrm{C}$, while the yield of bio-oil significantly increased in the presence of a catalyst at $300{ }^{\circ} \mathrm{C}$ and $350{ }^{\circ} \mathrm{C}$.

To understand the effect of a catalyst in a solvent other that water, Khampuang et al. [94] investigated the effect of $\mathrm{NaOH}(10 \mathrm{wt} \%)$ and $\mathrm{KOH}(10 \mathrm{wt} \%)$ on the liquefaction of corncobs in an ethanol (100\%) solvent. The result showed a steep increase in bio-oil yield from $38.6 \mathrm{wt} \%$ (no catalyst) to $50.5 \mathrm{wt} \%(\mathrm{NaOH})$ and $55.6 \mathrm{wt} \%(\mathrm{KOH})$, adding to the practicality of alkali for HTL in alcohol solvents, too. In many cases, feedstock is pretreated in an alkaline medium instead of adding a catalyst to the reactor medium. Liu et al. [39] compared the yield of bio-oil from un-pretreated cypress ( $27.5 \mathrm{wt} \%$ ) and alkaline pretreated biomass (44-48 $\mathrm{wt} \%$ ) at $300{ }^{\circ} \mathrm{C}$ and observed significant increase in the yield of bio-oil in the case of the alkaline-pretreated feedstock.

Akhtar et al. [108] studied the effect of various concentrations of $\mathrm{K}_{2} \mathrm{CO}_{3}(0.1-2.0 \mathrm{M})$ at $270{ }^{\circ} \mathrm{C}, 2 \mathrm{MPa}, 20 \mathrm{~min}$ for a biomass-to-water ratio of $5 \mathrm{~g} / 25 \mathrm{~mL}$, as shown in Figure 8 . They observed a significant increase in biomass degradation, mass conversion, and oil yield as the concentration increased from $0.1-1.0 \mathrm{M}$, followed by a steep decrease in biomass degradation and oil yield on increasing the catalyst concentration from 1.0-2.0 M. One possible explanation for the impeded liquid yield may be the repolymerization of small chain molecules at a higher concentration. Many other studies investigated the effect of catalyst concentration and found an increase in bio-oil yield up to a certain concentration as shown in Figure 8. This increase was followed by a decrease in yield after the catalyst concentration was increased further [111,117].

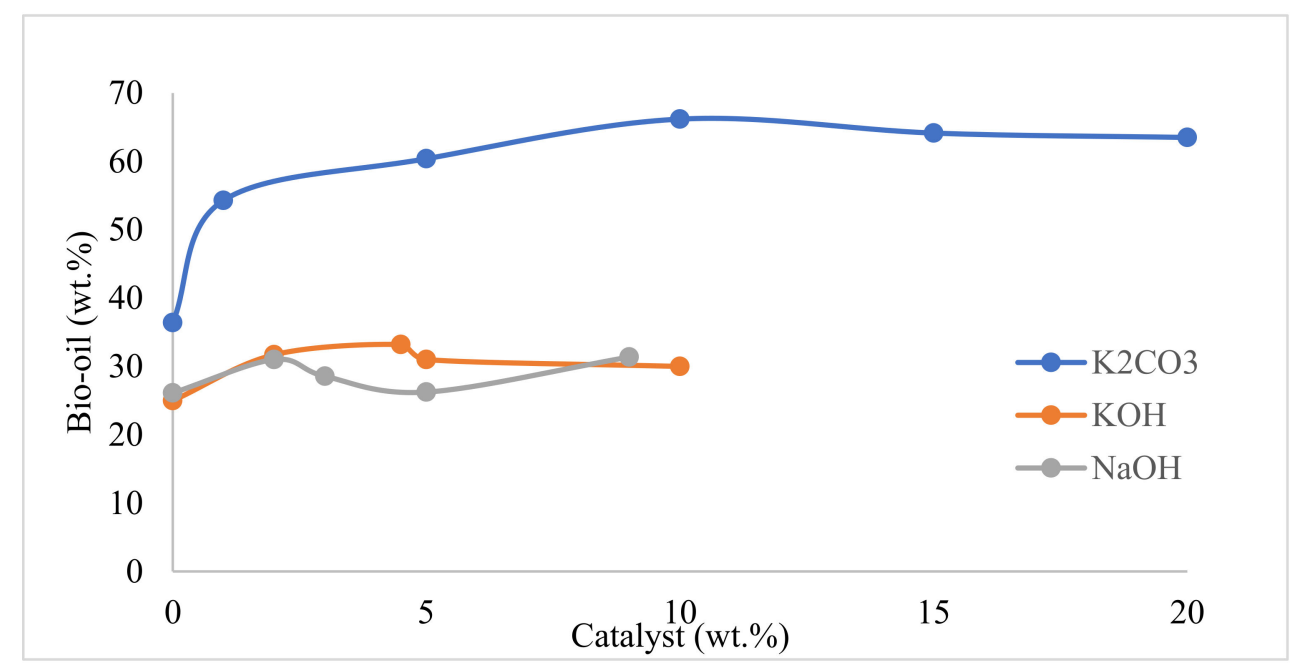

Figure 8. Effect of homogeneous catalyst concentration (alkali) on the yield of bio-oil.

Potassium carbonate is by far the most effective alkali catalyst to increase the yield of bio-oil in the optimum temperature range of $280-350{ }^{\circ} \mathrm{C}$. The $\mathrm{K}_{2} \mathrm{CO}_{3}$ reacts with water to 
form hydroxide and bicarbonate, which promotes the reaction pathway by acting as an intermediate [27], as shown below.

$$
\begin{aligned}
& \mathrm{K}_{2} \mathrm{CO}_{3}+\mathrm{H}_{2} \mathrm{O} \rightarrow \mathrm{KHCO}_{3}+\mathrm{KOH} \\
& 2 \mathrm{KHCO}_{3} \rightarrow \mathrm{H}_{2} \mathrm{O}+\mathrm{K}_{2} \mathrm{CO}_{3}+\mathrm{CO}_{2}
\end{aligned}
$$

The alkaline medium changes the reaction behavior of biomass and promotes the weakening of intramolecular interactions in glucoside bonds in the biomass, resulting in a decrease of the activation energy for complex reactions and reducing the thermal stability of stable chemical structures $[15,94]$. Furthermore, it disrupts the physical barriers in biomass, giving rise to the absorption of the solvent in the biomass. This causes a broader separation between the structural linkages in cellulose and lignin, which increases the surface availability to the interior structure and enhances the degradation [39,42]. Hence, when used in reasonable concentrations, alkali catalysts are advantageous to the HTL process and to increasing the bio-oil yield.

\subsubsection{Heterogeneous Catalysts}

Heterogeneous catalysts are also extensively studied for their application in the HTL process. Some of the main elements considered for use as catalysts are Fe [118], Cu [119], Ni [120], Al [121], Zn [122], Co [123], Pt [112], Mn, Ce, and Sn [103], either in their oxide, chloride, or sulfate form. Common supports used in the studies include Si-Al [29], $\mathrm{Al}_{2} \mathrm{O}_{3}$ [124], SBA-15 [121], MCM-41 [125], carbon nanotubes (CNTs) [112], HZSM-5 [123], and zeolites [29]. In studies, many minerals, such as colemanite [66], hydrotalcite [66], hematite [125], magnetite [31], and borax [36], found in local regions, are also investigated to understand their effect on the HTL process.

\begin{tabular}{|c|c|c|c|c|c|c|c|c|c|}
\hline Feedstock & $\begin{array}{l}\text { Process } \\
\text { Condition }\end{array}$ & Catalysts & $\begin{array}{l}\text { Product } \\
\text { Yield } \\
\text { (wt } \%)\end{array}$ & $\begin{array}{l}\mathrm{HHV}^{*} \\
\left(\mathrm{MJ} \mathrm{kg}^{-1}\right)\end{array}$ & $\underset{(w t \%)}{C^{*}}$ & $\underset{\left(w^{*} \%\right)}{H^{*}}$ & $\underset{(w t \%)}{O^{*}}$ & Oil Properties & Ref. \\
\hline \multirow{2}{*}{$\begin{array}{l}\text { Wood } \\
\text { (konara) }\end{array}$} & \multirow{2}{*}{$\begin{array}{l}\mathrm{T}^{*}: 350{ }^{\circ} \mathrm{C} \\
\mathrm{P}_{\mathrm{i}} *: 2 \mathrm{MPa} \\
\mathrm{R}_{\mathrm{t}}^{*}: 30 \mathrm{~min}\end{array}$} & - & $\mathrm{HO}^{*}: 5.0$ & 28.9 & 70.9 & 6.9 & 22.1 & - & \multirow[b]{2}{*}{ [88] } \\
\hline & & $\mathrm{K}_{2} \mathrm{CO}_{3}$ & $\begin{array}{c}\mathrm{HO}: \\
21.4-26.2\end{array}$ & $30.4-33.4$ & $71.8-76.6$ & $6.8-7.7$ & $15.9-21.2$ & - & \\
\hline \multirow{7}{*}{$\begin{array}{l}\text { Sawdust } \\
\text { (pine wood) }\end{array}$} & \multirow{7}{*}{$\begin{array}{l}\mathrm{T}: 280^{\circ} \mathrm{C} \\
\mathrm{R}_{\mathrm{t}}: 15 \mathrm{~min}\end{array}$} & - & $\mathrm{BO} *: 8.6$ & - & - & - & - & $\begin{array}{l}\text { EEO *: aldehydes }(18 \%), \\
\text { ketones }(8 \%), \text { phenolics }(45 \%), \\
\text { fatty acids }(8 \%) \\
\text { EAO *: unsaturated chain } \\
(26 \%), \text { ketones }(11 \%), \\
\text {-oic acid }(32 \%)\end{array}$ & \multirow{7}{*}[70,109]{} \\
\hline & & $\mathrm{NaOH}$ & BO: 22.4 & \multirow{6}{*}{-} & \multirow{6}{*}{-} & \multirow{6}{*}{ - } & \multirow{6}{*}{-} & \multirow{6}{*}{$\begin{array}{c}\text { EEO: acetic acid }(3-12 \%), \\
\text { phenolics }(50-70 \%) \\
\text { benzenediols }(10-25 \%) \\
\text { EAO: ketones (45-60\%), } \\
\text { unsaturated chains }(15-25 \%)\end{array}$} & \\
\hline & & $\mathrm{Na}_{2} \mathrm{CO}_{3}$ & BO: 23.0 & & & & & & \\
\hline & & $\mathrm{KOH}$ & BO: 28.7 & & & & & & \\
\hline & & $\mathrm{K}_{2} \mathrm{CO}_{3}$ & $\begin{array}{c}\text { Total oil: } \\
33.7\end{array}$ & & & & & & \\
\hline & & $\mathrm{RbOH}$ & BO: 23.8 & & & & & & \\
\hline & & $\mathrm{CsOH}$ & BO: 20.8 & & & & & & \\
\hline \multirow{4}{*}{$\begin{array}{l}\text { Empty palm } \\
\text { fruit bunch }\end{array}$} & \multirow{4}{*}{$\begin{array}{l}\mathrm{T}: 270^{\circ} \mathrm{C} \\
\mathrm{P}_{\mathrm{i}}: 2 \mathrm{MPa} \\
\mathrm{R}_{\mathrm{t}}: 20 \mathrm{~min}\end{array}$} & - & $\mathrm{LP} *: 30$ & - & - & - & - & Methyl esters $(26.44 \%)$ & \multirow{4}{*}{ [108] } \\
\hline & & $\mathrm{NaOH}$ & LP: 58 & - & - & - & - & $\begin{array}{c}\text { Phenols (6\%), } \\
\text { methyl ester }(86.45 \%)\end{array}$ & \\
\hline & & $\mathrm{KOH}$ & LP: 58 & - & - & - & - & $\begin{array}{c}\text { Phenols (18.4\%), } \\
\text { methyl ester }(81.6 \%)\end{array}$ & \\
\hline & & $\mathrm{K}_{2} \mathrm{CO}_{3}$ & LP: $\sim 63$ & - & - & - & - & $\begin{array}{c}\text { Phenols }(60.08 \%), \\
\text { methyl ester }(39.92 \%)\end{array}$ & \\
\hline
\end{tabular}

Table 9. Effect of catalyst during HTL process. 
Table 9. Cont.

\begin{tabular}{|c|c|c|c|c|c|c|c|c|c|}
\hline Feedstock & $\begin{array}{l}\text { Process } \\
\text { Condition }\end{array}$ & Catalysts & $\begin{array}{l}\text { Product } \\
\text { Yield } \\
\text { (wt } \%)\end{array}$ & $\begin{array}{l}\mathrm{HHV}^{*} \\
\left(\mathrm{MJ} \mathrm{kg}^{-1}\right)\end{array}$ & $\underset{(w t \%)}{C^{*}}$ & $\underset{\left(w^{*} \%\right)}{H^{*}}$ & $\underset{(w t \%)}{O^{*}}$ & Oil Properties & Ref. \\
\hline \multirow{3}{*}{$\begin{array}{c}\text { Wood } \\
\text { (Paulownia) }\end{array}$} & $\begin{array}{l}\mathrm{T}: 300^{\circ} \mathrm{C} \\
\mathrm{R}_{\mathrm{t}}: 10 \mathrm{~min}\end{array}$ & - & HO: 26 & 26.3 & - & - & - & $\begin{array}{c}\text { Phenolics }(37 \%), \text { ketones }(13 \%), \\
\text { carboxylic acid/ester }(17 \%), \\
\text { phenyl derivatives }(3 \%)\end{array}$ & \multirow{3}{*}{ [41] } \\
\hline & $\begin{array}{l}\mathrm{T}: 300^{\circ} \mathrm{C} \\
\mathrm{R}_{\mathrm{t}}: 10 \mathrm{~min}\end{array}$ & $\mathrm{Na}_{2} \mathrm{CO}_{3}$ & HO: 31.5 & 28.1 & - & - & - & $\begin{array}{c}\text { Phenolics }(39 \%), \text { ketones }(17 \%), \\
\text { carboxylic acid/ester }(7 \%), \\
\text { phenyl derivatives }(10 \%)\end{array}$ & \\
\hline & $\begin{array}{l}\mathrm{T}: 340^{\circ} \mathrm{C} \\
\mathrm{R}_{\mathrm{t}}: 10 \mathrm{~min}\end{array}$ & $\mathrm{Fe}$ & HO: 36 & 31.5 & - & - & - & $\begin{array}{c}\text { Phenolics }(38 \%), \text { ketones }(20 \%), \\
\text { carboxylic acid/ester }(6 \%), \\
\text { phenyl derivatives }(3 \%), \text { long } \\
\text { chain alkanes }(2 \%)\end{array}$ & \\
\hline \multirow{3}{*}{$\begin{array}{l}\text { Pulp/paper } \\
\text { mill sludge }+ \\
\text { newspaper } \\
\text { waste }\end{array}$} & \multirow{3}{*}{$\begin{array}{l}\mathrm{T}: 300^{\circ} \mathrm{C} \\
\mathrm{R}_{\mathrm{t}}: 20 \mathrm{~min}\end{array}$} & $\dot{\mathrm{KOH}}$ & $\begin{array}{l}\text { BO: } 24.9 \\
\text { BO: } 31.2\end{array}$ & $\begin{array}{l}29.5 \\
29.5\end{array}$ & $\begin{array}{l}70.5 \\
70.2\end{array}$ & $\begin{array}{l}6.8 \\
6.9\end{array}$ & $\begin{array}{l}22.4 \\
22.4\end{array}$ & $\begin{array}{l}- \\
-\end{array}$ & \multirow{3}{*}[75]{} \\
\hline & & $\mathrm{HCOOH}$ & BO: 34.4 & 29.5 & 69.9 & 6.9 & 22.1 & - & \\
\hline & & $\mathrm{FeS}$ & BO: 27.7 & 29.9 & 71.4 & 6.7 & 21.4 & - & \\
\hline \multirow{4}{*}{$\begin{array}{l}\text { Beech } \\
\text { wood }\end{array}$} & \multirow{4}{*}{$\begin{array}{l}\mathrm{T}: 300^{\circ} \mathrm{C} \\
\mathrm{R}_{\mathrm{t}}: 0 \mathrm{~min}\end{array}$} & \multirow[b]{2}{*}{-} & LO *: 6.2 & 22.9 & 60 & 6 & 34 & $\begin{array}{c}\text { Furfurals }(13 \%), \text { ketones } \\
(12.7 \%), \text { phenolics }(22 \%), \\
\text { benzenediols }(5.2 \%)\end{array}$ & \multirow{4}{*}{ [43] } \\
\hline & & & HO: 14.8 & 24.4 & 60 & 7 & 33 & $\begin{array}{c}\text { Acetic acid }(2 \%), \text { ketones } \\
(6.4 \%) \text {, phenolics }(11.3 \%) \\
\text { FAAE }^{*}(3 \%)\end{array}$ & \\
\hline & & \multirow[t]{2}{*}{ Colemanite } & LO: 11.1 & 21.2 & 59.6 & 6.6 & 36.4 & $\begin{array}{c}\text { Ketones }(12 \%) \text {, phenolics } \\
(29.4 \%) \text {, benzenediols }(7.3 \%)\end{array}$ & \\
\hline & & & HO: 29.8 & 25.2 & 62.5 & 6.7 & 31 & $\begin{array}{l}\text { Acetic acid }(2 \%), \text { ketones } \\
(21.8 \%), \text { phenolics }(14 \%)\end{array}$ & \\
\hline \multirow{4}{*}{$\begin{array}{l}\text { Scotch pine } \\
\text { wood }\end{array}$} & \multirow{4}{*}{$\begin{array}{l}\mathrm{T}: 300^{\circ} \mathrm{C} \\
\mathrm{R}_{\mathrm{t}}: 0 \mathrm{~min}\end{array}$} & \multirow{2}{*}{ - } & LO: 4.5 & 22.9 & 60 & 6.1 & 33.9 & $\begin{array}{l}\text { Furfurals, ketones, } \\
\text { phenolics, FAAE }\end{array}$ & \multirow{4}{*}{ [43] } \\
\hline & & & HO: 19 & 27.1 & 66.6 & 6.6 & 26.8 & $\begin{array}{c}\text { Ketones (16\%), phenolics } \\
(9.6 \%), \text { FAAE }(18)\end{array}$ & \\
\hline & & \multirow{2}{*}{$\mathrm{NaBO}_{3} \cdot \mathrm{H}_{2} \mathrm{O}$} & LO: 7 & 24.2 & 61 & 6.6 & 32.5 & $\begin{array}{l}\text { Acetic acid, ketones, phenolics, } \\
\text { phenyl derivatives, FAAE }\end{array}$ & \\
\hline & & & HO: 33 & 28.6 & 68 & 7.1 & 24.9 & $\begin{array}{c}\text { Ketones (60), phenolics (4.4), } \\
\text { FAAE }(9 \%)\end{array}$ & \\
\hline \multirow{4}{*}{$\begin{array}{l}\text { Oil palm } \\
\text { shell }\end{array}$} & \multirow{4}{*}{$\begin{array}{l}\mathrm{T}: 330^{\circ} \mathrm{C} \\
\mathrm{R}_{\mathrm{t}}: 60 \mathrm{~min}\end{array}$} & - & BO: 14.2 & 33.1 & 79.4 & 6.3 & 13.3 & $\begin{array}{l}\text { Hexadecanoic acid (54\%), } \\
\text { 6-octadecanoic acid (21.3\%), } \\
\text { oleic acid (26\%) }\end{array}$ & \multirow{4}{*}{ [42] } \\
\hline & & $\mathrm{K}_{2} \mathrm{CO}_{3}$ & BO: 27.9 & 34.4 & 80.7 & 6.7 & 11.8 & $\begin{array}{l}\text { Benzenediols (51\%), catechols } \\
(24 \%) \text {, dihydroxytoluene }(13 \%)\end{array}$ & \\
\hline & & $\mathrm{Na}_{2} \mathrm{CO}_{3}$ & BO: 26.3 & 32.9 & 76.5 & 7.1 & 15.9 & $\begin{array}{l}\text { Benzenediols }(52 \%) \text {, catechols } \\
(24.5 \%) \text {, ethylene oxide }(18 \%) \text {, } \\
\text { methyl tetradecanoate }(13 \%)\end{array}$ & \\
\hline & & $\mathrm{NaOH}$ & BO: 23.9 & 31.1 & 69.9 & 8 & 21.5 & $\begin{array}{c}\text { Benzenediols }(73 \%) \text {, catechols } \\
(16.4 \%) \text {, dihydroxytoluene } \\
(8.3 \%) \text {, ethylene oxide }(2.3 \%)\end{array}$ & \\
\hline \multirow{2}{*}{ Cypress } & \multirow{2}{*}{$\stackrel{\mathrm{T}:}{260-300{ }^{\circ} \mathrm{C}}$} & - & $\begin{array}{c}\text { BO: } \\
27.5-31.1\end{array}$ & - & - & - & - & \multirow{2}{*}{$\begin{array}{l}\text { Ethanol insoluble organics, } \\
\text { ethanol soluble organics, DEE } \\
\text { soluble and insoluble oil }\end{array}$} & \multirow{2}{*}{ [39] } \\
\hline & & $\begin{array}{l}\text { Alkaline } \\
\text { pretreated }\end{array}$ & $\begin{array}{c}\text { BO: } \\
29.7-48.4\end{array}$ & - & - & - & - & & \\
\hline \multirow{2}{*}{$\begin{array}{l}\text { Barley } \\
\text { straw }\end{array}$} & \multirow{2}{*}{$\mathrm{T}: 300^{\circ} \mathrm{C}$} & - & $\mathrm{BC}^{*}: 17.88$ & 24.9 & 62.6 & 6.4 & 29.8 & $\begin{array}{l}\text { Phenolics }+ \text { alcohols }(12.6 \%) \\
\text { ketones }(13 \%),- \text {-oic acids }(29 \%), \\
\text { aldehydes }(7.7 \%)\end{array}$ & \multirow{2}{*}{ [15] } \\
\hline & & $\mathrm{K}_{2} \mathrm{CO}_{3}$ & BC: 34.85 & 27.3 & 67.9 & 7.6 & 23.2 & $\begin{array}{c}\text { Phenolics + alcohols }(12.8 \%), \\
\text { ketones }(13 \%),- \text { oic acids }(24 \%), \\
\text { aldehydes }(7 \%)\end{array}$ & \\
\hline \multirow{2}{*}{$\begin{array}{l}\text { Waste } \\
\text { bamboo } \\
\text { chopstick }\end{array}$} & \multirow{2}{*}{$\begin{array}{c}\mathrm{T}: \\
290-380^{\circ} \mathrm{C} \\
\mathrm{R}_{\mathrm{t}}: 30 \mathrm{~min}\end{array}$} & - & $\begin{array}{c}\text { BO: } \\
1.2-3.7 \\
\end{array}$ & $29.7-30.9$ & $65.6-68.4$ & $6.7-7.4$ & $5.5-5.6$ & - & \multirow{2}{*}{ [80] } \\
\hline & & $\mathrm{K}_{2} \mathrm{CO}_{3}$ & $\begin{array}{c}\text { BO: } \\
7.1-21.2\end{array}$ & $31.6-33.9$ & $66.4-74.2$ & $6.7-7.4$ & $18.4-25.1$ & - & \\
\hline \multirow{3}{*}{$\begin{array}{l}\text { Datura } \\
\text { stramonium } \\
\text { L. stems }\end{array}$} & \multirow{3}{*}{$\mathrm{T}: 300^{\circ} \mathrm{C}$} & - & BO: 32 & - & - & - & - & $\begin{array}{l}\text { Cyclic HC * }(15 \%) \text {, saturated } \\
\text { chain HC }(56 \%) \text {, acids }(13.4 \%)\end{array}$ & \\
\hline & & Borax & BO: 36 & - & - & - & - & $\begin{array}{c}\text { Ketones }(7.2 \%), \text { cyclic HC }(2 \%) \\
\text { saturated chain HC }(52 \%) \\
\text { acids }(4.2 \%)\end{array}$ & [36] \\
\hline & & Colemanite & BO: 40.2 & - & - & - & - & $\begin{array}{c}\text { Ketones }(6.7 \%) \text {, cyclic HC } \\
(0.5 \%) \text {, saturated chain HC } \\
(28 \%) \text {, acids }(5.5 \%)\end{array}$ & \\
\hline
\end{tabular}


Table 9. Cont.

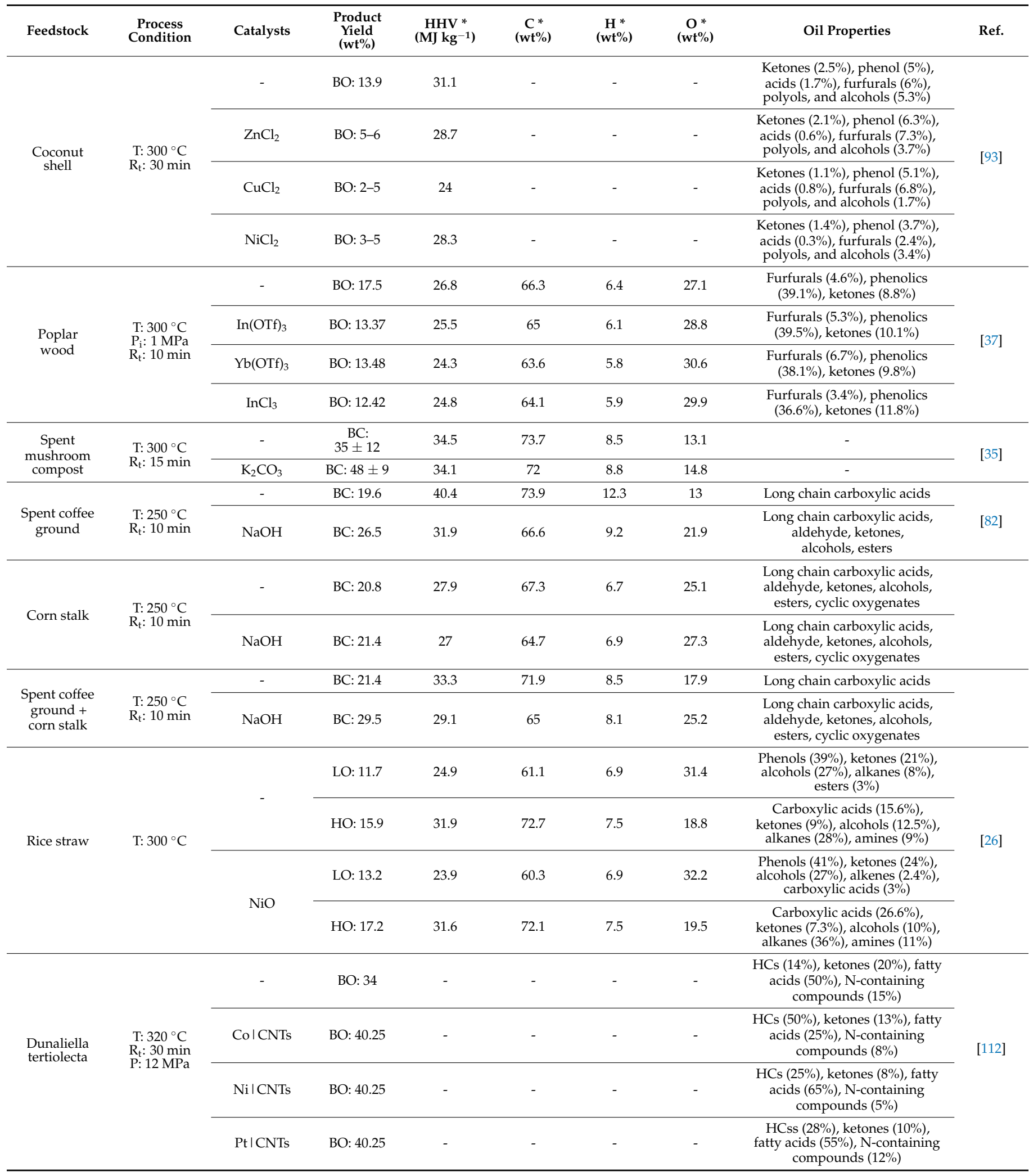


Table 9. Cont.

\begin{tabular}{|c|c|c|c|c|c|c|c|c|c|}
\hline Feedstock & $\begin{array}{l}\text { Process } \\
\text { Condition }\end{array}$ & Catalysts & $\begin{array}{l}\text { Product } \\
\text { Yield } \\
(w t \%)\end{array}$ & $\underset{\left(\mathrm{MJ} \mathrm{kg}^{-1}\right)}{\mathrm{HHV}^{*}}$ & $\underset{(w t \%)}{C^{*}}$ & $\underset{(\mathbf{w t} \%)}{\mathrm{H}^{*}}$ & $\underset{(w t \%)}{O^{*}}$ & Oil Properties & Ref. \\
\hline \multirow{3}{*}{$\begin{array}{l}\text { Pretreated } \\
\text { sorghum } \\
\text { Bagasse }\end{array}$} & \multirow{3}{*}{$\mathrm{T}: 300^{\circ} \mathrm{C}$} & $\mathrm{K}_{2} \mathrm{CO}_{3}$ & BC: 61.8 & 33.1 & 73.2 & 7.7 & 15 & $\begin{array}{c}\text { Ketones }(3 \%) \text {, alcohols }(1.5 \%) \text {, } \\
\text { HCs }(0.6 \%), \text { phenolics }(22 \%), \\
\text { esters }(3.2 \%) \text {, phenyl deriv. }(4 \%)\end{array}$ & \multirow{3}{*}{ [29] } \\
\hline & & $\mathrm{KOH}$ & BC: 42.2 & 30 & 64.3 & 7.6 & 14.5 & $\begin{array}{c}\text { Ketones }(4 \%) \text {, alcohols }(0.5 \%), \\
\text { HCs }(0.8 \%) \text {, phenolics }(23 \%), \\
\text { esters }(10 \%) \text {, phenyl deri }(1.7 \%)\end{array}$ & \\
\hline & & $\mathrm{Ni} \mid \mathrm{Si}-\mathrm{Al}$ & BC: 45.5 & 21.5 & 50.2 & 5.9 & 21.5 & $\begin{array}{c}\text { Ketones }(5 \%) \text {, alcohols }(2 \%), \\
\text { HCs }(2.2), \text { phenolics }(15 \%), \\
\text { esters }(2.7 \%) \text {, phenyl deri }(4.2)\end{array}$ & \\
\hline \multirow{2}{*}{$\begin{array}{l}\text { Spruce } \\
\text { wood }\end{array}$} & \multirow{2}{*}{$\begin{array}{l}\mathrm{T}: 300^{\circ} \mathrm{C} \\
\mathrm{P}_{\mathrm{i}}: 2 \mathrm{MPa} \\
\mathrm{R}_{\mathrm{t}}: 30 \mathrm{~min}\end{array}$} & - & BO: 6.6 & - & - & - & - & $\begin{array}{l}\text { Ketones }(29.4 \%) \text {, phenolics } \\
(40.6 \%), \text { FAAE }(9.6 \%)\end{array}$ & \multirow{2}{*}{ [124] } \\
\hline & & $\mathrm{KF} / \mathrm{Al}_{2} \mathrm{O}_{3}$ & BO: 13.9 & 28.42 & 68.3 & 6.8 & 24.8 & $\begin{array}{c}\text { Ketones }(23.7 \%), \text { phenolics } \\
(44.7 \%), \text { FAAE }(8.7 \%)\end{array}$ & \\
\hline
\end{tabular}

* HO: heavy oil, BO: bio-oil, BC: bio-crude, LO: light oil, LP: liquid products, HHV; higher heating value, C: carbon, H: hydrogen, O: oxygen; $\mathrm{P}_{\mathrm{i}}$ : initial pressure, $\mathrm{P}_{\mathrm{f}}$ : final pressure, $\mathrm{T}$ : temperature, $\mathrm{R}_{\mathrm{t}}$ : retention time, FAAE: fatty acid alky ester, HC: hydrocarbon; EAO: ethyl acetate oil phase, EEO: ethyl ether oil phase.

Zhang et al. [75] studied the effect of adding homogeneous catalysts $(\mathrm{HCOOH}, \mathrm{KOH})$ and heterogeneous catalysts (FeS) on the liquefaction of secondary pulp/paper mill sludge at $300{ }^{\circ} \mathrm{C}, 20 \mathrm{~min}$. The reactivity order of the catalyst according to the bio-oil yield was found to be $\mathrm{HCOOH}(34.4 \mathrm{wt} \%)>\mathrm{KOH}(31.2 \mathrm{wt} \%)>\mathrm{FeS}(27.7 \mathrm{wt} \%)>$ thermal $(24.9 w \mathrm{t} \%)$; there was no significant difference observed in the elemental analysis and higher heating value of oil obtained in the presence of different catalysts. Bi et al. [29] studied various catalysts and arranged them as per their efficacy to produce the bio-crude as $\mathrm{K}_{2} \mathrm{CO}_{3}>$ $\mathrm{Ni} / \mathrm{Si}-\mathrm{Al}>\mathrm{KOH}>$ none. It was observed that, when compared to $\mathrm{Ni} / \mathrm{Si}-\mathrm{Al}$ run and catalyst free run, bio-oil obtained in the presence of $\mathrm{K}_{2} \mathrm{CO}_{3}$ and $\mathrm{KOH}$ has a significantly high percentage of a carbon and HHV value. Caprariis et al. [31] examined the effect of Fe powder, $\mathrm{Fe}_{2} \mathrm{O}_{3}$, and $\mathrm{Fe}_{3} \mathrm{O}_{4}$ in a reducing gas $\left(\mathrm{H}_{2}\right)$ environment and found that the highest bio-oil yield and the lowest char was obtained in the presence of Fe powder. Fe begins to oxidize with water over $250{ }^{\circ} \mathrm{C}$ and its oxidation increases with a temperature increase. The oxidation of Fe produces $\mathrm{H}_{2}$ gas (equation). This prevents the repolymerization and condensation of precursors formed in water, such as 5-HMF (5-hydroxymethylfurfural), which is responsible for bio-oil formation and, thus, reduces char formation. $\mathrm{Fe}^{3+}$ in $\mathrm{Fe}_{2} \mathrm{O}_{3}$ being in higher oxidation state failed to increase the bio-oil yield, whereas $\mathrm{Fe}^{2+}$ in $\mathrm{Fe}_{3} \mathrm{O}_{4}$ still had excellent oxidation capability and, therefore, contributed to the degradation and dehydration of lignocellulosic components, leading to the dehydration of fructose (isomerized glucose) and promoting the formation of 5-HMF [51,64,126].

In a study on the loading capacity of the potassium fluoride-doped aluminum oxide $\left(\mathrm{KF} / \mathrm{AL}_{2} \mathrm{O}_{3}\right)$ catalyst on product yield, Alper et al. [124] showed an increase in bio-oil yield when the loading capacity increased from $10 \mathrm{wt} \%$ to $20 \mathrm{wt} \%$ as shown in Figure $9 \mathrm{a}$. This was followed by decrease in bio-oil when the loading was increased to $40 \mathrm{wt} \%$. One possible reason for the decrease in bio-oil at a high solid base concentration of a $\mathrm{KF} / \mathrm{Al}_{2} \mathrm{O}_{3}$ catalyst in HTL may be the Cannizzaro reaction. In this reaction, the aldehyde initially produces alcohol and acid, which, on further decomposition, results in increasing the gaseous fraction. Jie et al. [121] studied the effect of an SBA-15-supported nickel metal catalyst (Ni/SBA-15) on the HTL process and the yield of bio-oil. As shown in Figure 9a, the liquefaction of rice straw at $280^{\circ} \mathrm{C}$ and 15 min undoubtedly yielded more bio-oil in the range of $56.2-56.6 \mathrm{wt} \%$ of bio-oil at $10-15 \mathrm{wt} \%$ loading of $\mathrm{Ni} / \mathrm{SBA}-15$ in comparison to the lower catalyst $\mathrm{w} t \%$ or non-catalytic run. It was also observed that on a further increase of the catalyst to $20 \mathrm{wt} \%$, the bio-oil yield was reduced to $55.1 \mathrm{wt} \%$, which was caused by the enhanced cracking of macromolecules in rice straw to non-condensable gases [117]. Other research also examined the effect of the $\mathrm{w} \mathrm{t} \%$ of heterogeneous catalysts on the yield of biooil, as shown in Figure 9b, and found it to negatively affect the yield of bio-oil [37]. Thus, the selection of the catalyst is an important task in the HTL process. Both homogenous 
and heterogeneous catalysts were found effective in increasing the bio-oil yield and quality when used in measured and experimental amounts. $\mathrm{K}_{2} \mathrm{CO}_{3}$ is undoubtedly an excellent choice. It helps to increase the bio-oil yield, reduce the char formation, and significantly improve the quality of oil by increasing the carbon content and reducing oxygen, adding to a higher HHV value.
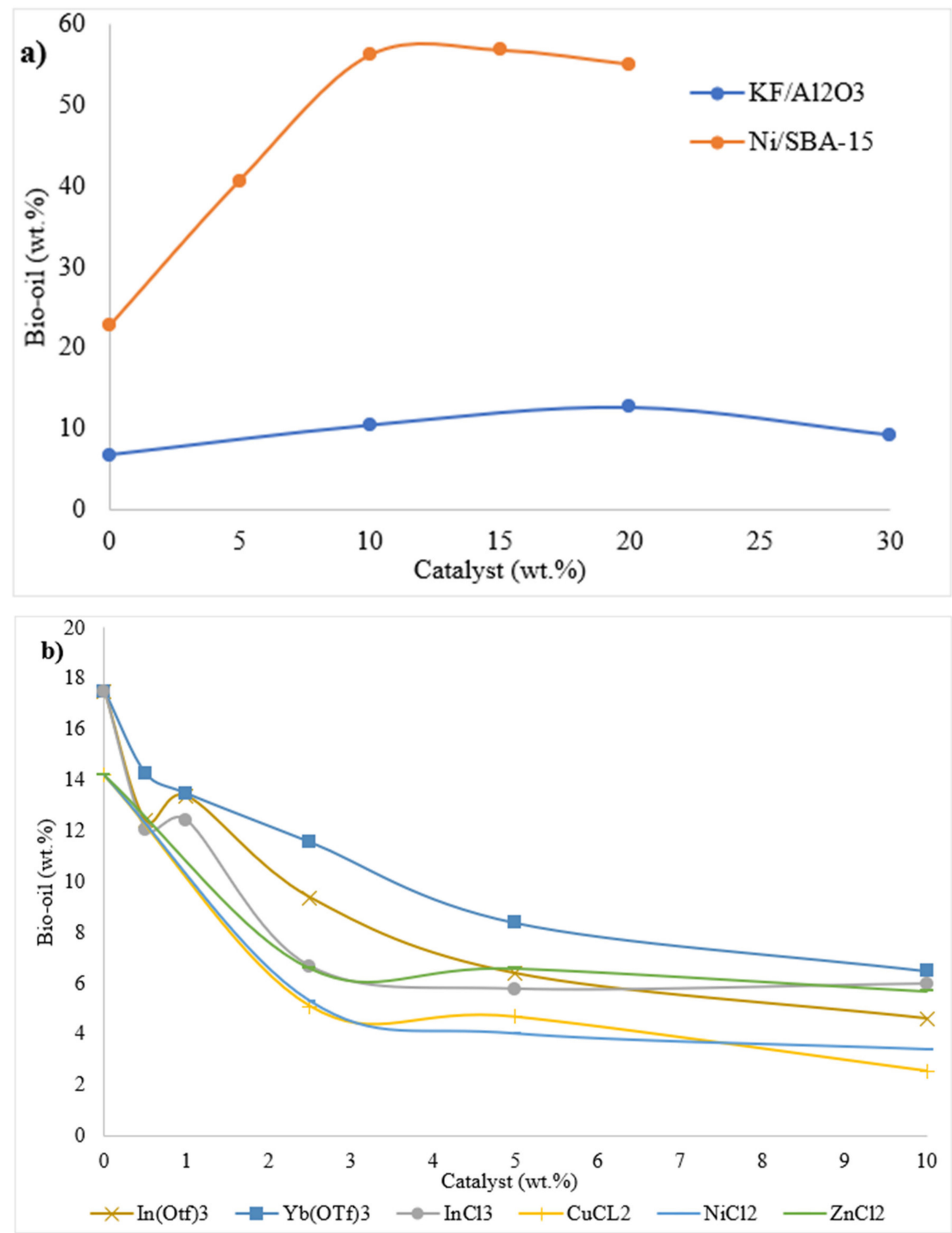

Figure 9. Effect of heterogeneous catalyst concentration on the yield of bio-oil (a) catalyst with positive effect, (b) catalyst with negative effect. 


\subsection{Effect of Solvents and Co-Solvents}

The HTL process requires solvents that can effectively convert biomass into highenergy density fuels of desired composition. In the last two decades, many solvents have been utilized for the HTL process as described in Table 10.

Table 10. Studies focused on effect of various solvents for HTL.

\begin{tabular}{ccc}
\hline S. No & Year & Description/Objective \\
\hline 1 & 2010 & $\begin{array}{r}\text { Highly efficient liquefaction of woody } \\
\text { biomass in hot-compressed } \\
\text { alcohol-water co-solvents. }\end{array}$ \\
\hline 2 & 2010 & $\begin{array}{c}\text { Bio-oil from hydro-liquefaction of } \\
\text { bagasse in supercritical ethanol. }\end{array}$ \\
& & \\
3 & 2012 & $\begin{array}{c}\text { Direct liquefaction of Dunaliella } \\
\text { tertiolecta for bio-oil in } \\
\text { sub/supercritical ethanol-water. }\end{array}$
\end{tabular}

$42013 \quad$ Synergic effect of methanol and water on pine liquefaction. solvent (ethanol-water).

$62014 \quad$ Cornstalk liquefaction in methanol/water mixed solvents.

\section{Results/Observations/Major Findings}

Co-solvent mixture of ethanol-water is more attractive for biomass liquefaction since ethanol is a renewable source of energy, which is easily produced from fermentation of sugars.

Increased concentrations of ethanol in ethanol-water mixture resulted in higher heavy oil yield and higher HHV.

Compound groups of phenolic, esters, and aldehydes were mostly found in heavy oil.

Low ash content was found in heavy oil obtained using ethanol-water mixture, making the heavy oil useful as a cleaner fuel, when compared to heavy oil obtained using only pure water during liquefaction. Ethanol react with amides and/or acids to form ethyl esters, and act as hydrogen-donor during liquefaction process.

$50 \mathrm{vol} \%$ water content enhanced solvolytic liquefaction of pine.

Mixture of methanol and water promoted more decomposition of some plant tissue in pine when compared to using purely methanol or water.

Heavy oil obtained after liquefaction in ethanol-water mixture, showed mostly phenolic and ester compounds to be present.

Presence of ethanol allowed high yields of heavy oil with less severity in operation during liquefaction.

50:50 $(v / v)$ of methanol-water mixture provided highest heavy oil at $300{ }^{\circ} \mathrm{C}$ and $15 \mathrm{~min}$ of liquefaction process.
Increasing water content led to cornstalk hydrolysis and increasing methanol content led to esterification reactions.
Ref.

For liquefaction of wheat straw, the optimum water-ethanol mixture ratio of 50:50 $(v / v)$ was found to be effective in producing high yield of heavy oil and $\mathrm{HHV}$ at $300^{\circ} \mathrm{C}$ and $10 \mathrm{MPa}$.

Increasing trend of HHV was observed with increase in ethanol concentrations, with $95 \mathrm{vol} \%$ ethanol to give the highest HHV of heavy oil produced after liquefaction.

Phenolic compounds and esters in heavy oil were observed to be decreasing with increase in water content.

Alcohols, aromatics, and heterocyclic compounds in heavy oil, were maximum when $50 \mathrm{vol} \%$ ethanol was used for liquefaction.

70:30 $(v / v)$ water-methanol mixtures resulted in complete degradation of cellulose and hemicellulose than for lignin. 
Table 10. Cont.

\begin{tabular}{|c|c|c|c|c|}
\hline S. No & Year & Description/Objective & Results/Observations/Major Findings & Ref. \\
\hline 10 & 2016 & $\begin{array}{l}\text { Continuous hydrothermal liquefaction } \\
\text { of macroalgae in the presence of } \\
\text { organic co-solvents. }\end{array}$ & $\begin{array}{l}\text { Anisole-water mixture produced high yields of } \\
\text { heavy oil when compared to those when liquefied } \\
\text { using toluene-water or n-heptane-water mixtures. } \\
\text { Viscosity of heavy oil when liquefaction was } \\
\text { conducted with anisole-water mixture was much } \\
\text { higher when compared to those obtained by using } \\
\text { toluene-water and n-heptane-water mixtures. }\end{array}$ & [135] \\
\hline 11 & 2018 & $\begin{array}{c}\text { Comparative study on lignocellulose } \\
\text { liquefaction in water, ethanol, and } \\
\text { water/ethanol mixture: role of ethanol } \\
\text { and water. }\end{array}$ & $\begin{array}{c}\text { Mixed ethanol/water solvent promoted the } \\
\text { permeation of the solvent into the lignocellulosic } \\
\text { structure and increased solubility of intermediates. } \\
\text { Hot compressed water was found to promote } \\
\text { hydrolysis of cellulose and hemicellulose, and } \\
\text { ethanol was found to accelerate degradation } \\
\text { of lignin. }\end{array}$ & [136] \\
\hline 12 & 2018 & $\begin{array}{l}\text { Highly efficient conversion of camphor } \\
\text { tree sawdust into bio-oil and biochar } \\
\text { products by liquefaction in } \\
\text { ethanol-water co-solvent. }\end{array}$ & $\begin{array}{l}50: 50(v / v) \text { ethanol-water mixture efficiently } \\
\text { liquefied camphor tree sawdust at } 280^{\circ} \mathrm{C} \text { for } 30 \mathrm{~min} \text {, } \\
\text { with heavy oil yield of } 61.5 \mathrm{wt} \% \text {, higher conversion } \\
\text { rate of } 98.4 \% \text {, and energy recovery rate of } 94.5 \% \text {. } \\
\text { Heavy oil produced using ethanol-water mixture } \\
\text { resulted in higher contents of esters and ketones and } \\
\text { lower amounts of nitrogenous compounds. }\end{array}$ & [137] \\
\hline 13 & 2018 & $\begin{array}{l}\text { Liquefaction of sewage sludge in } \\
\text { ethanol-water mixed solvents for } \\
\text { bio-oil and biochar products. }\end{array}$ & $\begin{array}{l}\text { Optimum ethanol-water mixture of } 75: 25(v / v) \\
\text { provided the highest heavy oil yield at } 220^{\circ} \mathrm{C} \text { and } \\
30 \text { min liquefaction conditions. The synergistic effect } \\
\text { of ethanol-water mixture allowed liquefaction to be } \\
\text { conducted at mild operating conditions with } \\
\text { elevated yield and quality of heavy oil. }\end{array}$ & [138] \\
\hline 14 & 2018 & $\begin{array}{l}\text { Sub- and supercritical liquefaction of } \\
\text { municipal wet sewage sludge to } \\
\text { produce bio-oil: effect of different } \\
\text { organic-water mixed solvents. }\end{array}$ & $\begin{array}{l}\text { Methanol-water mixture promoted high content of } \\
\text { ester due to esterification. n-hexane-water promoted } \\
\text { more aliphatic compounds to be formed, due to its } \\
\text { high solubility in n-hexane. } \\
\text { Low-boiling point materials were found more in } \\
\text { heavy oil obtained by methanol-water liquefaction. } \\
\text { Oxygen content in heavy oil reduced significantly in } \\
\text { n-hexane-water liquefaction. }\end{array}$ & [139] \\
\hline 15 & 2019 & $\begin{array}{l}\text { Effect of co-solvent and addition of } \\
\text { catalyst (HZSM-5) on hydrothermal } \\
\text { liquefaction of macroalgae. }\end{array}$ & $\begin{array}{c}\text { Liquefaction of macroalgae at } 300{ }^{\circ} \mathrm{C} \text { and } 45 \mathrm{~min} \text {, } \\
\text { using } 75 \mathrm{vol} \% \text { ethanol, provided the highest heavy } \\
\text { oil yield of } 46.75 \mathrm{wt} \% \text {. } \\
\text { Catalyst HZSM-5 failed to provide high yield of } \\
\text { heavy oil; however, quality of heavy oil was } \\
\text { improved with high amounts of ester compounds. }\end{array}$ & [140] \\
\hline 16 & 2020 & $\begin{array}{l}\text { Alkali-catalyzed liquefaction of } \\
\text { pinewood sawdust in ethanol/water } \\
\text { co-solvents. }\end{array}$ & $\begin{array}{c}\text { Yield of heavy oil obtained by using ethanol-water } \\
\text { mixture for liquefaction can be compromised by } \\
\text { using } \mathrm{Na}_{2} \mathrm{CO}_{3} \text { or } \mathrm{NaOH} \text { as catalyst. }\end{array}$ & [141] \\
\hline 17 & 2021 & $\begin{array}{l}\text { HTL of olive oil residue. } \\
\text { Understanding the effect of using } \\
\text { supercritical methanol as solvent on } \\
\text { HTL of olive oil residue. }\end{array}$ & $\begin{array}{l}\text { At } 300{ }^{\circ} \mathrm{C} \text { and } 15 \mathrm{~min} \text {, the use of methanol as solvent } \\
\text { increased the oil yield from } 30.8 \mathrm{wt} \% \text { to } 33.5 \mathrm{wt} \% \text {, } \\
\text { which further increased to } 40.3 \mathrm{wt} \% \text { in the presence } \\
\text { of } \mathrm{AlCl}_{3} .\end{array}$ & [85] \\
\hline 18 & 2021 & $\begin{array}{l}\text { Subcritical hydrothermal } \\
\text { co-liquefaction of process rejects at a } \\
\text { waste paper-based paper mill with } \\
\text { waste soybean oil. } \\
\text { Effect of solvent ratio of waste soybean } \\
\text { oil (WSO)-water was studied. }\end{array}$ & $\begin{array}{c}\text { The highest HHV value of product was } \\
\text { 42.02 } \mathrm{MJ} \mathrm{kg}^{-1} \text { at WSO-water ratio of 25:75. } \\
\text { The conversion was found to be highest at } \\
\text { WSO-water ratio of 100:00. } \\
\text { The percentage of alcohols, benzene, alkenyl, } \\
\text { phenols, and ester decreased with the increase of } \\
\text { WSO-water ratio, whereas the percentage of acids } \\
\text { increased up to a WSO-water ratio of 50:50 on } \\
\text { further increase of the WSO-water ratio. }\end{array}$ & [142] \\
\hline
\end{tabular}


Among the HTL solvents, water is highly desirable for many liquefaction processes, since it is the least expensive, is easily accessibility, and shows favorable chemical properties that efficiently facilitate reactions. Water acts as reaction medium, solvent, and catalyst to support various reactions during HTL. Water is considered one of the "green solvents", and with its physical and chemical properties at subcritical and supercritical states, it is able to extract useful products from biomass during the liquefaction process [143]. The critical point of water is $374{ }^{\circ} \mathrm{C}$ and $22 \mathrm{MPa}$; above the supercritical point, water has no phase boundaries, making it an excellent solvent. In this region, water has a high tendency of diffusion and mass transfer owing to its low viscosity and high miscibility [3]. Below the supercritical condition lies the subcritical zone of intermediate temperature which supports primary hydrolysis and radical reactions through the formation of a pool of $\mathrm{H}^{+}$ and $\mathrm{OH}^{-}$ions [144]. However, both Ogi et al. [145] and Yuan et al. [146] have written about obtaining highly viscous, tarry lumps of heavy oil when liquefaction is conducted with only water as a solvent. Yuan et al. [146] further found that the efficiency of the liquefaction of lignocellulosic biomass can be increased by using solvent mixtures rather than using only one kind of solvent. As shown in Table 11, many different solvents have been studied for the HTL of a varied range of biomasses, to understand the effect of solvents on the product yield and composition.

Table 11. Major solvents and co-solvents used in the HTL process.

\begin{tabular}{|c|c|c|c|c|c|c|c|c|c|}
\hline Biomass & $\begin{array}{l}\text { Operation } \\
\text { Condition }\end{array}$ & Co-Solvents & $\begin{array}{l}\text { Oil } \\
\text { Yield } \\
(w t \%)\end{array}$ & $\begin{array}{l}\text { HHV } \\
(\mathrm{MJ} \\
\left.\mathrm{kg}^{-1}\right)\end{array}$ & $\underset{\text { (wt.) }}{C}$ & $\underset{\text { (wt.) }}{\mathrm{H}}$ & $\underset{(w t .)}{O}$ & Comments & Ref. \\
\hline \multirow{2}{*}{ Rice straw } & \multirow{2}{*}{$\begin{array}{l}\mathrm{T}: 300^{\circ} \mathrm{C} \\
\mathrm{R}: 3 \mathrm{~min}\end{array}$} & $\begin{array}{l}50 \text { vol\% } \\
\text { Ethanol }\end{array}$ & 38.35 & 29.66 & - & - & - & \multirow{2}{*}{$\begin{array}{l}\text { Bio-oil yield increased with solvent-water } \\
\text { ratio, ranging from } 0 \text { to } 50 \mathrm{vol} \% \text {, and } \\
\text { decreased afterwards. } \\
\text { Yields of residue were higher when } \\
\text { ethanol-water was used, when compared to } \\
\text { 2-propanol-water mixture during the } \\
\text { liquefaction process. }\end{array}$} & \multirow{2}{*}{ [146] } \\
\hline & & $\begin{array}{c}50 \text { vol\% } \\
\text { 2-Propanol }\end{array}$ & 39.70 & 30.75 & 63.81 & 7.10 & 27.29 & & \\
\hline \multirow{5}{*}{ Rice straw } & \multirow{5}{*}{$\begin{array}{l}\mathrm{T}: 300^{\circ} \mathrm{C} \\
\mathrm{R}: 5 \mathrm{~min}\end{array}$} & Water & 18.51 & 30.77 & 72.57 & 6.88 & 20.55 & \multirow{5}{*}{$\begin{array}{l}\text { Phenolic compounds are majorly present in } \\
\text { liquefied products along with ester derivatives, } \\
\text { hydrocarbons, organic acids, and alcohols. }\end{array}$} & \multirow{5}{*}{ [147] } \\
\hline & & $\begin{array}{c}20 \text { vol } \% \\
1,4 \text {-dioxane }\end{array}$ & 22.80 & 37.17 & 79.25 & 8.69 & 12.06 & & \\
\hline & & $\begin{array}{c}50 \text { vol\% } \\
\text { 1,4-dioxane }\end{array}$ & 14.34 & 32.99 & 75.48 & 7.32 & 17.20 & & \\
\hline & & $\begin{array}{c}80 \text { vol\% } \\
\text { 1,4-dioxane }\end{array}$ & 17.33 & 32.28 & 74.74 & 7.12 & 18.14 & & \\
\hline & & 1,4-dioxane & 12.43 & 37.07 & 77.66 & 9.14 & 13.20 & & \\
\hline \multirow{5}{*}{ Pine wood } & \multirow{5}{*}{$\begin{array}{l}\mathrm{T}: 300{ }^{\circ} \mathrm{C} \\
\mathrm{R}: 15 \mathrm{~min}\end{array}$} & Water & 39.13 & & & & & \multirow{5}{*}{$\begin{array}{c}\text { Liquefaction conducted with } 50 \mathrm{wt} \% \text { methanol } \\
\text { or ethanol in solvent-water mixture resulted in } \\
>95 \mathrm{wt} \% \text { conversion of biomass and yield of } \\
\text { bio-oil was }>65 \mathrm{wt} \% \text { at } 300{ }^{\circ} \mathrm{C} \text { and a residence } \\
\text { time of } 15 \mathrm{~min} \text {, compared to the runs using } \\
\text { mono-solvents. }\end{array}$} & \multirow{5}{*}{ [127] } \\
\hline & & $\begin{array}{l}50 \mathrm{wt} \% \\
\text { Ethanol }\end{array}$ & 65.74 & & & & & & \\
\hline & & Ethanol & 25.92 & - & - & - & - & & \\
\hline & & $\begin{array}{c}50 w t \% \\
\text { Methanol }\end{array}$ & 64.45 & & & & & & \\
\hline & & Methanol & 23.54 & & & & & & \\
\hline \multirow{5}{*}{$\begin{array}{l}\text { Sugarcane } \\
\text { bagasse }\end{array}$} & \multirow{5}{*}{$\begin{array}{l}\mathrm{T}: 330^{\circ} \mathrm{C} \\
\mathrm{R}: 40 \mathrm{~min}\end{array}$} & $\begin{array}{l}50 \mathrm{vol} \% \\
\text { Ethanol }\end{array}$ & 42.44 & 21.4 & - & - & - & \multirow{5}{*}{$\begin{array}{c}\text { For } 95 \mathrm{vol} \% \text { ethanol and } 5 \mathrm{vol} \% \text { water mixture, } \\
\text { there was a decrease in the amount of gas and } \\
\text { water products, resulting in a higher yield of } \\
\text { heavy oil. } \\
\text { HHV increased with increasing ethanol } \\
\text { concentrations, until } 95 \mathrm{vol} \% \text { ethanol. }\end{array}$} & \multirow{5}{*}{ [128] } \\
\hline & & $\begin{array}{l}70 \text { vol\% } \\
\text { Ethanol }\end{array}$ & 41.48 & 24.6 & - & - & - & & \\
\hline & & $\begin{array}{l}90 \mathrm{vol} \% \\
\text { Ethanol }\end{array}$ & 45.03 & 24.7 & - & - & - & & \\
\hline & & $\begin{array}{l}95 \text { vol\% } \\
\text { Ethanol }\end{array}$ & 48.24 & 27.1 & 56.5 & 6.8 & 34.7 & & \\
\hline & & Ethanol & 39.55 & 24.2 & - & - & - & & \\
\hline
\end{tabular}


Table 11. Cont.

\begin{tabular}{|c|c|c|c|c|c|c|c|c|c|}
\hline Biomass & $\begin{array}{l}\text { Operation } \\
\text { Condition }\end{array}$ & Co-Solvents & $\begin{array}{l}\text { Oil } \\
\text { Yield } \\
(\mathbf{w t} \%)\end{array}$ & $\begin{array}{l}\mathrm{HHV} \\
(\mathrm{MJ} \\
\left.\mathrm{kg}^{-1}\right)\end{array}$ & $\underset{\text { (wt.) }}{C}$ & $\underset{(w t .)}{H}$ & $\underset{\text { (wt.) }}{\mathrm{O}}$ & Comments & Ref. \\
\hline \multirow{3}{*}{ Rice husk } & \multirow{3}{*}{$\begin{array}{l}\mathrm{T}: 260^{\circ} \mathrm{C} \\
\mathrm{R}: 20 \mathrm{~min}\end{array}$} & Water & 13.16 & 25.03 & 60.55 & 6.93 & 30.24 & \multirow{3}{*}{$\begin{array}{l}\text { Optimum ratio of 5:5 }(\mathrm{v} / \mathrm{v}) \text { ethanol-water } \\
\text { mixture provided relatively high yield of oil } \\
\text { with low oxygen content. Ethanol provided } \\
\text { decomposition of macromolecules such as } \\
\text { cellulose, hemicellulose, and lignin, at milder } \\
\text { operating conditions. }\end{array}$} & \multirow{3}{*}{ [130] } \\
\hline & & $\begin{array}{l}50 \text { vol\% } \\
\text { Ethanol }\end{array}$ & 21.07 & 27.04 & 64.88 & 6.78 & 25.99 & & \\
\hline & & Ethanol & 18.44 & 27.56 & 63.63 & 7.46 & 26.23 & & \\
\hline \multirow{5}{*}{ Pine wood } & \multirow{5}{*}{$\begin{array}{l}\mathrm{T}: 300^{\circ} \mathrm{C} \\
\mathrm{R}: 15 \mathrm{~min}\end{array}$} & Methanol & 24.25 & \multirow{5}{*}{-} & \multirow{5}{*}{-} & \multirow{5}{*}{ - } & \multirow{5}{*}{ - } & \multirow{5}{*}{$\begin{array}{l}\text { More heavy oil was converted to char at } \\
\text { reaction temperatures above } 300^{\circ} \mathrm{C} \text {. Heavy oil } \\
\text { yield increased until } 15 \text { min residence time } \\
\text { after which both gas and residue yields } \\
\text { started increasing. }\end{array}$} & \multirow{5}{*}{ [40] } \\
\hline & & $\begin{array}{l}20 \text { vol } \% \\
\text { Methanol }\end{array}$ & 40.02 & & & & & & \\
\hline & & $\begin{array}{l}50 \text { vol\% } \\
\text { Methanol }\end{array}$ & 54.65 & & & & & & \\
\hline & & $\begin{array}{l}80 \mathrm{vol} \% \\
\text { Methanol }\end{array}$ & 27.79 & & & & & & \\
\hline & & Water & 29.96 & & & & & & \\
\hline \multirow{5}{*}{$\begin{array}{l}\text { Wheat } \\
\text { straw }\end{array}$} & \multirow{5}{*}{$\begin{array}{l}\mathrm{T}: 300{ }^{\circ} \mathrm{C} \\
\mathrm{R}: 120 \mathrm{~min}\end{array}$} & Water & 25.8 & 20.5 & \multirow{5}{*}{ - } & \multirow{5}{*}{ - } & \multirow{5}{*}{-} & \multirow{5}{*}{$\begin{array}{l}\text { Water-ethanol mixture of } 50: 50(v / v) \text { used } \\
\text { during liquefaction of wheat straw at } 300{ }^{\circ} \mathrm{C} \\
\text { and } 100 \text { bar, effectively produced high heavy } \\
\text { oil yield of } 30.4 \mathrm{wt} \% \text { with } \mathrm{HHV} \text { of } 27.8 \mathrm{MJ} \mathrm{kg} \mathrm{kg}^{-1} \text {. }\end{array}$} & \multirow{5}{*}{ [132] } \\
\hline & & $\begin{array}{l}25 \mathrm{vol} \% \\
\text { Ethanol }\end{array}$ & 22.2 & 25.5 & & & & & \\
\hline & & $\begin{array}{l}50 \text { vol\% } \\
\text { Ethanol }\end{array}$ & 30.4 & 27.8 & & & & & \\
\hline & & $\begin{array}{l}75 \text { vol\% } \\
\text { Ethanol }\end{array}$ & 32.7 & 28.5 & & & & & \\
\hline & & Ethanol & 43.2 & 28.2 & & & & & \\
\hline \multirow{6}{*}{ Cornstalk } & \multirow{6}{*}{$\begin{array}{l}\mathrm{T}: 300{ }^{\circ} \mathrm{C} \\
\mathrm{R}: 30 \mathrm{~min}\end{array}$} & Water & 45.15 & \multirow{6}{*}{-} & \multirow{6}{*}{-} & \multirow{6}{*}{-} & \multirow{6}{*}{-} & \multirow{6}{*}{$\begin{array}{c}\text { Isometric methanol/water } 50: 50(v / v) \text { showed } \\
\text { the best synergistic effect on degradation } \\
\text { of lignin. }\end{array}$} & \multirow{6}{*}{ [131] } \\
\hline & & $\begin{array}{l}20 \text { vol } \% \\
\text { Methanol }\end{array}$ & 45.71 & & & & & & \\
\hline & & $\begin{array}{c}40 \mathrm{vol} \% \\
\text { Methanol }\end{array}$ & 48.07 & & & & & & \\
\hline & & $\begin{array}{c}50 \mathrm{vol} \% \\
\text { Methanol }\end{array}$ & 52.40 & & & & & & \\
\hline & & $\begin{array}{l}80 \mathrm{vol} \% \\
\text { Methanol }\end{array}$ & 43.92 & & & & & & \\
\hline & & Methanol & 28.10 & & & & & & \\
\hline \multirow{7}{*}{ Poplar } & \multirow{7}{*}{$\begin{array}{l}\mathrm{T}: 300^{\circ} \mathrm{C} \\
\mathrm{R}: 15 \mathrm{~min}\end{array}$} & Water & 28.8 & & & & & & \\
\hline & & $\begin{array}{l}20 \mathrm{vol} \% \\
\text { Methanol }\end{array}$ & 36.2 & & & & & & \\
\hline & & $\begin{array}{l}30 \mathrm{vol} \% \\
\text { Methanol }\end{array}$ & 38.9 & & & & & $\begin{array}{l}\text { More amounts of ketone, aldehyde, and } \\
\text { carboxylic acid were found in heavy oil }\end{array}$ & \\
\hline & & $\begin{array}{l}40 \text { vol } \% \\
\text { Methanol }\end{array}$ & 37.3 & - & - & - & - & $\begin{array}{l}\text { liquefied with } 70: 30(v / v) \\
\text { water-methanol mixture. } \\
\text { Yield of esters decreased with an increase in }\end{array}$ & [134] \\
\hline & & $\begin{array}{l}60 \text { vol } \% \\
\text { Methanol }\end{array}$ & 31.8 & & & & & water content in the solvent mixture. & \\
\hline & & $\begin{array}{l}80 \mathrm{vol} \% \\
\text { Methanol }\end{array}$ & 32.8 & & & & & & \\
\hline & & Methanol & 23.2 & & & & & & \\
\hline Rice straw & $\begin{array}{l}\mathrm{T}: 260^{\circ} \mathrm{C} \\
\mathrm{R}: 60 \mathrm{~min}\end{array}$ & $\begin{array}{l}\text { Glycerol- } \\
\text { water } \\
(1: 1)(\mathrm{mL})\end{array}$ & 21.69 & 30.06 & 68.17 & 7.71 & 22.30 & $\begin{array}{c}50 \mathrm{vol} \% \text { glycerol decomposes the } \\
\text { lignocellulosic components to produce free } \\
\text { phenoxyl radicals that enable new compounds } \\
\text { to be formed by } \\
\text { condensation/repolymerization reactions, } \\
\text { receding the residue formation. }\end{array}$ & [148] \\
\hline & & $\begin{array}{c}10 \mathrm{wt} \% \\
\mathrm{n} \text {-heptane }\end{array}$ & 7.23 & & & & & & \\
\hline Macroalgae & $\begin{array}{l}\mathrm{T}: 350{ }^{\circ} \mathrm{C} \\
\mathrm{R}: 3 \mathrm{~min}\end{array}$ & $\begin{array}{l}10 w t \% \\
\text { Toluene }\end{array}$ & 14.88 & - & - & - & - & $\begin{array}{l}\text { Anisole led to an increase in heavy oil yield } \\
\text { when compared to n-heptane and toluene. }\end{array}$ & [135] \\
\hline & & $\begin{array}{l}10 w t \% \\
\text { Anisole }\end{array}$ & 24.44 & & & & & & \\
\hline
\end{tabular}


Table 11. Cont.

\begin{tabular}{|c|c|c|c|c|c|c|c|c|c|}
\hline Biomass & $\begin{array}{l}\text { Operation } \\
\text { Condition }\end{array}$ & Co-Solvents & $\begin{array}{l}\text { Oil } \\
\text { Yield } \\
\left(w t^{\%}\right)\end{array}$ & $\begin{array}{l}\mathrm{HHV} \\
(\mathrm{MJ} \\
\left.\mathrm{kg}^{-1}\right)\end{array}$ & $\underset{\text { (wt.) }}{C}$ & $\underset{\text { (wt.) }}{H}$ & $\underset{(w t .)}{O}$ & Comments & Ref. \\
\hline $\begin{array}{l}\text { Camphor } \\
\text { tree } \\
\text { sawdust } \\
\text { (CTS) }\end{array}$ & $\begin{array}{c}\mathrm{T}: 280^{\circ} \mathrm{CR}: \\
30 \mathrm{~min}\end{array}$ & $\begin{array}{l}50: 50(v / v) \\
\text { Water- } \\
\text { ethanol }\end{array}$ & 61.5 & 24.6 & 61.6 & 6.5 & 31.6 & $\begin{array}{l}\text { Conversion rate can be arranged from high to } \\
\text { low efficiency of liquefaction as ethanol-water } \\
>\text { only water }>\text { only ethanol. }\end{array}$ & [135] \\
\hline \multirow{5}{*}{$\begin{array}{l}\text { Sewage } \\
\text { sludge }\end{array}$} & \multirow{5}{*}{$\begin{array}{l}\mathrm{T}: 220^{\circ} \mathrm{C} \\
\mathrm{R}: 30 \mathrm{~min}\end{array}$} & Water & 55.38 & 20.30 & 45.90 & 7.50 & 33.30 & \multirow{5}{*}{$\begin{array}{l}\text { Heavy oil obtained by using ethanol-water } \\
\text { mixture showed less content of long chain } \\
\text { carbon compounds (>C70), when compared to } \\
\text { using pure water as a solvent. }\end{array}$} & \multirow{5}{*}{ [138] } \\
\hline & & $\begin{array}{l}25 \text { vol\% } \\
\text { Ethanol }\end{array}$ & 55.52 & - & - & - & - & & \\
\hline & & $\begin{array}{l}50 \text { vol\% } \\
\text { Ethanol }\end{array}$ & 34.87 & 25.10 & 54.50 & 7.90 & 26.40 & & \\
\hline & & $\begin{array}{l}75 \text { vol\% } \\
\text { Ethanol }\end{array}$ & 58.15 & - & - & - & - & & \\
\hline & & Ethanol & 66.41 & 27.00 & 58.40 & 8.00 & 24.10 & & \\
\hline \multirow{2}{*}{$\begin{array}{l}\text { Sewage } \\
\text { sludge }\end{array}$} & \multirow{2}{*}{$\begin{array}{l}\mathrm{T}: 340^{\circ} \mathrm{C} \\
\mathrm{R}: 20 \mathrm{~min}\end{array}$} & $\begin{array}{l}50 \text { vol } \% \\
\text { Methanol }\end{array}$ & 39.4 & $\begin{array}{l}34.14 \\
\pm \\
0.48\end{array}$ & $\begin{array}{l}73.94 \\
\pm \\
0.34\end{array}$ & $\begin{array}{l}10.55 \\
\pm \\
0.22\end{array}$ & $\begin{array}{l}9.34 \\
\pm \\
0.32\end{array}$ & \multirow{2}{*}{$\begin{array}{l}\text { Effect of the reaction temperature on the yield } \\
\text { of heavy oil using different solvents showed } \\
\text { fewer changes, whereas the effect of the } \\
\text { residence time created significant changes to } \\
\text { heavy oil yield. }\end{array}$} & \multirow{2}{*}{ [139] } \\
\hline & & $\begin{array}{c}50 \text { vol\% } \\
\text { n-hexane }\end{array}$ & 38.6 & $\begin{array}{l}36.45 \\
\pm \\
0.38\end{array}$ & $\begin{array}{l}73.08 \\
\pm \\
0.23\end{array}$ & $\begin{array}{l}10.75 \\
\pm \\
0.12\end{array}$ & $\begin{array}{c}7.65 \\
\pm \\
0.26\end{array}$ & & \\
\hline \multirow{5}{*}{ Macroalgae } & \multirow{5}{*}{$\begin{array}{l}\mathrm{T}: 300^{\circ} \mathrm{C} \\
\mathrm{R}: 45 \mathrm{~min}\end{array}$} & Water & 13.93 & & - & - & - & \multirow{5}{*}{$\begin{array}{l}\text { Using } 75 \mathrm{vol} \% \text { ethanol required high pressures } \\
\text { of } 20 \mathrm{MPa} \text {; hence, } 50 \mathrm{vol} \% \text { ethanol can be } \\
\text { considered as optimum alcohol-water mixture } \\
\text { that produced a similar yield of heavy oil with } \\
\text { reduced operating pressure required } \\
\text { for liquefaction. }\end{array}$} & \multirow{5}{*}{ [140] } \\
\hline & & $\begin{array}{l}25 \text { vol\% } \\
\text { Ethanol }\end{array}$ & 23.22 & & - & - & - & & \\
\hline & & $\begin{array}{l}50 \text { vol\% } \\
\text { Ethanol }\end{array}$ & 44.94 & - & 63.48 & 5.88 & 22.18 & & \\
\hline & & $\begin{array}{l}75 \text { vol\% } \\
\text { Ethanol }\end{array}$ & 46.75 & & - & - & - & & \\
\hline & & Ethanol & 42.29 & & - & - & - & & \\
\hline $\begin{array}{c}\text { Pinewood } \\
\text { sawdust }\end{array}$ & $\begin{array}{l}\mathrm{T}: 300^{\circ} \mathrm{C} \\
\mathrm{R}: 30 \mathrm{~min}\end{array}$ & $\begin{array}{l}50 \mathrm{wt} \% \\
\text { Ethanol }\end{array}$ & $\begin{array}{c}47.63 \\
\pm \\
0.09\end{array}$ & 25.89 & 65.60 & 6.13 & 28.24 & $\begin{array}{l}\text { Heavy oil obtained by using ethanol-water } \\
\text { mixture contains high content of mild boiling } \\
\text { point materials (range of } 343-538^{\circ} \mathrm{C} \text { ) than } \\
\text { those obtained by using pure water for } \\
\text { liquefaction. }\end{array}$ & [141] \\
\hline
\end{tabular}

Some of the most common solvents used for the HTL process are acetone, methanol, ethanol, 2-propanol, n-hexane, and n-heptane. Often these solvents are used as a co-solvent with water. Several studies have focused on understanding and optimizing the ratio of solvents with respect to water to improve product yield and quality. Ogi et al. [145] suggested that adding organic solvents with water to biomass can improve the efficiency of the continuous liquefaction process by making the heavy oil less viscous. They studied solvents, such as acetone, propanol, butanol, methyl ethyl ketone, and EAC for liquefaction and found that an acetone-water mixture produced heavy oil with less viscosity. In another study, Ogi et al. [149] conducted hydrothermal liquefaction of oak wood chips with water and 2-propanol at $275{ }^{\circ} \mathrm{C}$ for $60 \mathrm{~min}$. The water and 2-propanol ratio of 15:15 $(v / v) \mathrm{mL}$ provided the highest yield of heavy oil $(75.7 \mathrm{wt} \%)$. Heavy oil obtained using the water and 2-propanol mixture resulted in decreased viscosity with no changes in the elemental composition.

Yuan et al. [146] investigated the effects of an organic solvent-water mixture ratio on HHV and the yield of heavy oil and solid residue at subcritical and supercritical conditions, respectively. Liquefaction using either an ethanol-water or 2-propanol-water mixture resulted in an increase in the heavy oil yield with an increase in the organic solvent-water ratio from $0 / 10(v / v)$ to $5 / 5(v / v)$ and a decrease in heavy oil yield on further increase of organic solvent. Yuan et al. [146] concluded that low-boiling point compounds, including gaseous products, can be reduced by using an organic solvent-water mixture rather than using purely one kind of solvent for liquefaction. Furthermore, a 2-propanol-water mixture was found to provide both a higher yield of heavy oil and HHV than the ethanol-water mixture for the liquefaction of rice straw. 
Minami et al. [150] reported the benefits of using supercritical methanol $\left(\mathrm{T}=239^{\circ} \mathrm{C}\right.$, $\mathrm{P}=8.1 \mathrm{MPa}$ ) as a co-solvent mixture with water for the liquefaction of beech wood. Methanol, which has critical temperatures and pressures lower than those of water, tends to lower the operating conditions of liquefaction. Methanol's dielectric constant lowers from 32 at ambient conditions to 7 when it reaches its critical point, which allows methanol to dissolve many kinds of nonpolar organic substances and inorganic gases. It was also observed that water played a significant role in the decomposition of lignin and hemicelluloses. Hence, a $10 \mathrm{vol} \%$ water with $90 \mathrm{vol} \%$ methanol proved to be effective for decomposition and liquefaction. Zhu et al. [131] studied the effect of using water, methanol and a methanol-water mixture as solvents for cornstalk liquefaction. It was found that a 50/50 $(v / v)$ ratio of a methanol-water mixture provided heavy oil with the highest phenol content. In a similar study, Yan et al. [134] reported that methanol is effective for the degradation of cellulose and hemicellulose, whereas better lignin degradation is found when only water is used. Water contributed to the hydrolysis of cellulose and hemicellulose components, and led to ketone formation through cyclization reactions and methanol-facilitated esterification reactions [131,134].

Another solvent to consider is ethanol, which acts as an effective reaction substrate and a hydrogen-donor solvent. It promotes heavy oil formation and reduces residual generation [130]. Cheng et al. [127] carried out the liquefaction of white pine sawdust at 200-350 ${ }^{\circ} \mathrm{C}$ and studied the effects of using pure solvents (methanol, ethanol and water) and co-solvents (methanol-water and ethanol-water) on heavy oil yield and its composition. A 50/50\% (w/w) methanol-water mixture and 50/50\% (w/w) ethanol-water mixture produced same yields of heavy oil and it was higher than that obtained during individual solvent run. Ethanol has been considered a better solvent than methanol in terms of the conversion rate of biomass, as ethanol reduces the surface tension of liquefied products and improves the diffusion of solvents in a lignin matrix. The FTIR results of heavy oil showed that ethanol plays a major role in lignin decomposition, whereas water contributed to the complete decomposition of cellulose and hemicellulose components of the biomass. Phenolic compounds were detected to be greater in heavy oil produced from liquefaction conducted with pure ethanol when compared to those obtained from an ethanol-water mixture [127].

Feng et al. [136] showed that the liquefaction process can be ranked from high to low efficiency based on the type of solvent media used and is arranged as: 50/50 (v/v) water-ethanol mixture $>$ pure water $>$ pure ethanol, irrespective of the type of biomass feedstock. A 50/50 (v/v) water-ethanol mixture showed a high synergistic effect during the liquefaction of lignocellulosic biomass conducted at $300{ }^{\circ} \mathrm{C}$ for a retention time of $15 \mathrm{~min}$. The role of water was primarily to hydrolyze cellulose and hemicellulose, whereas ethanol allowed lignin degradation, preventing further repolymerization reactions of intermediate materials. Since ethanol is primarily responsible for lignin degradation, using ethanol as the sole solvent can produce high quality heavy oil and is a better solvent medium for the liquefaction of high lignin-content biomass. Hence, for the liquefaction of biomass composed of all three major components (cellulose, hemicellulose and lignin), the ethanol-water mixture is more reliable, reducing the need to select a distinct type of biomass [136].

Li et al. [147] performed liquefaction of rice straw with a 1,4-dioxane-water mixture. The group studied the impact of a co-solvent mixture ratio on both the yield and quality of heavy oil. With the calculated values of critical temperature and pressure for a $50 \mathrm{vol} \%$ of 1,4-dioxane, it was noted that using a 1,4-dioxane-water mixture at a reaction temperature of $340{ }^{\circ} \mathrm{C}$ provided supercritical conditions which allowed chemical reactions to occur in a single fluid phase system [147]. The single fluid phase system provided the advantage of attaining higher concentrations of reactants, since there are no existing interphase mass transport processes that can hinder reaction rates [151]. The maximum oil yield of $22.80 \mathrm{wt} \%$ with the highest HHV (37.17 $\mathrm{MJ} \mathrm{kg}^{-1}$ ) was obtained for a $20 \mathrm{vol} \%$ of a 1,4dioxane-water mixture. Deoxygenation and decarboxylation reactions were occurring 
during the liquefaction of rice straw with a 1,4-dioxane water mixture, leading to an oxygen transfer from a heavy oil fraction to the aqueous phase, thus reducing the oxygen content of heavy oil. In regard to the decomposition mechanisms of lignin, cellulose, and hemicellulose, water acts as a nucleophile and reacts with some of the active centers in protolignin whereas 1,4-dioxane solubilizes cellulose and hemicellulose components and carries reactants to proto-lignin and the resulting lignin fragments to the solution $[147,152,153]$. $\mathrm{Li}$ et al. [147] also reported that nucleophilic and hydrolytic functions of water weakened with a higher content of 1,4-dioxane ( 80 and $100 \mathrm{vol} \%$ ) in a co-solvent mixture, thereby reducing the phenolic, acidic, hydrocarbon, and ester derivatives in heavy oil. Although $50 \mathrm{vol} \%$ 1,4-dioxane produced a high heavy oil yield, a reduced 1,4-dioxane content could potentially affect the quality of heavy oil in terms of the acid content. However, not many researchers have focused on the use of 1,4-dioxane due to its carcinogenic nature [148].

The use of other organic solvents is also reported for feedstocks other than pure lignocellulosic material, such as microalgae and sewage sludge. He et al. [135] reported the liquefaction of microalgae in the presence of individual $10 \mathrm{wt} \%$ anisole, toluene, and $\mathrm{n}$-heptane with water. It was observed that the anisole-water mixture led to a higher heavy oil yield compared to the yields obtained from using the toluene-water or n-heptanewater mixtures. One possible reason may be the increased solubility of anisole in water at temperatures above $275{ }^{\circ} \mathrm{C}$. Water alone provides limited solubility of organics, whereas in the presence of anisole the solubility of organics increases. Moreover, the anisole-water mixture inhibits the polymerization of reactive intermediates. However, heavy oil obtained from using the anisole-water co-solvent mixture showed higher viscosity than the heavy oil obtained with the other solvent-water mixtures. Li et al. [139] reported the effect of using a methanol-water mixture and an n-hexane-water mixture for the liquefaction of wet sewage sludge (WSS). Both the solid residue and gaseous products obtained were less when using the n-hexane-water co-solvent mixture when compared to using the methanol-water mixture. Interestingly it was observed that only at higher temperatures and pressures n-hexane showed better efficacy in extracting high yields of heavy oil, whereas methanol was able to produce similar yields at comparatively lower operating temperatures. In terms of calorific values obtained from heavy oil, the order of solvents was n-hexane-water $>$ methanol-water > pure water. Overall, the n-hexane-water mixture provided a higher heavy oil yield with a low oxygen content, high HHV and greater thermal stability, but at the cost of higher operating temperatures and pressures.

Therefore, the synergistic effect of using an organic solvent-water mixture improves the liquefaction process of biomass. The water promoted the decomposition of lignin, cellulose, and hemicellulose, and the hydrogen donor organic solvents showed greater affinity towards lignin decomposition, along with the reduction of intermediate polymerization and residual formation. The oil obtained showed reduced oxygen content and high carbon content and HHV value.

\subsection{Effect of Extraction Solvent on Products}

The procedure implemented to separate and extract the products from HTL of biomass plays a very important role. However, it is unclear how much the type of solvent used during heavy oil extraction affects the yield and composition. Tables 12 and 13 summarize some studies about the effect of different extraction solvents on the bio-oil yield and composition.

Many studies on the effect of extractive solvent are available for the HTL of microalgae. Valdez et al. [154] studied the effect of solvents on the yields and compositions of products recovered from the HTL of marine microalga Nannochloropsis sp. Polar solvents, such as methoxy cyclopentane, chloroform, and DCM, and non-polar solvents, such as hexadecane, decane, hexane, and cyclohexane were individually utilized for the extraction procedure. Non-polar solvents have been shown to increase the yield of bio-oil and aqueous phase oil when compared to yields from polar solvents [154]. The heavy oil extracted from using either polar or non-polar solvents was enriched with $\mathrm{C}$ and $\mathrm{H}$ content and had reduced 
the $\mathrm{N}$ content compared to the original feedstock composition. Heavy oil extracted with the polar solvent showed the highest carbon content. DCM showed the lowest heavy oil yield compared to the rest of the solvents [154]. The GC-MS analysis results showed heavy oil extracted using polar solvents had produced higher amounts of aliphatic compounds, whereas the heavy oil extracted using chlorinated solvents (chloroform and DCM) had high amounts of light ends and fatty acid derivatives. In a similar study, Yan et al. [155] examined the effect of 10 organic solvents with different polarities: isopropanol, EAC, DCM, DEE, dichloroethane, benzene, carbon disulfide, cyclohexane, n-hexane, and petroleum ether. Yan et al. [155] reported that solvents with higher polarity produced higher yields of heavy oil, a finding that contradicted Valdez [154].

Table 12. Studies on effect of extractive solvent in HTL operations.

\begin{tabular}{|c|c|c|c|c|}
\hline S. No & Year & Description/Objective & Results/Observations/Major Findings & Ref. \\
\hline 1 & 2011 & $\begin{array}{l}\text { Characterization of product fractions } \\
\text { from hydrothermal liquefaction of } \\
\text { Nannochloropsis sp. and the influence } \\
\text { of solvents. }\end{array}$ & $\begin{array}{l}\text { Non-polar solvents have been observed to provide high } \\
\text { gravimetric yields of heavy oil, but these oils contain low } \\
\text { carbon content and show less energy density. } \\
\text { Polar solvents have shown low yields of heavy oil, but these } \\
\text { oils contain high fatty acid content. }\end{array}$ & [154] \\
\hline 2 & 2014 & $\begin{array}{l}\text { Selective extraction of bio-oil from } \\
\text { hydrothermal liquefaction of Salix } \\
\text { psammophila by organic solvents with } \\
\text { different polarities through multistep } \\
\text { extraction separation. }\end{array}$ & $\begin{array}{l}\text { Heavy oil was extracted using } 9 \text { organic solvents with } \\
\text { different polarities in the order of high to low } \\
\text { efficiency-THF }>\text { toluene }>\text { EAC }>\text { acetone }>\text { ether }>\text { DCM }> \\
\text { methanol }>\text { petroleum ether }>\text { n-hexane. }\end{array}$ & [32] \\
\hline 3 & 2016 & $\begin{array}{l}\text { Analysis of physicochemical } \\
\text { properties of bio-oil from HTL of } \\
\text { blackcurrant pomace. }\end{array}$ & $\begin{array}{l}\text { Highest yield of heavy oil was obtained by using acetone as } \\
\text { an extraction solvent. } \\
\text { Heavy oil extracted by hexane was suggested to be the best } \\
\text { performing fuel in terms of quality since the heavy oil } \\
\text { showed low carbon residue, volatility close to that of diesel } \\
\text { and HHV close to those fuels used in marine applications. }\end{array}$ & [69] \\
\hline 4 & 2016 & $\begin{array}{l}\text { Composition of the bio-oil from the } \\
\text { HTL of duckweed and the influence of } \\
\text { the extraction solvents. }\end{array}$ & $\begin{array}{l}\text { Polarity and molecular structure of extraction solvent greatly } \\
\text { affects the yield and composition of heavy oil. } \\
\text { Heavy oil extracted by using polar solvents showed high } \\
\text { yields, high C and H content, and high energy density when } \\
\text { compared to those extracted by using non-polar solvents. }\end{array}$ & [155] \\
\hline 5 & 2019 & $\begin{array}{l}\text { 110th anniversary: influence of } \\
\text { solvents on bio-crude from } \\
\text { hydrothermal liquefaction of soybean } \\
\text { oil, soy protein, cellulose, xylose, and } \\
\text { lignin, and their quinary mixture. }\end{array}$ & $\begin{array}{l}\text { Solvent type for extraction was confirmed to affect the yield } \\
\text { of heavy oil recovered from two different HTL processes. } \\
\text { Polarity of solvent cannot be the sole determinant of } \\
\text { evaluating its performance during the extraction process. }\end{array}$ & [68] \\
\hline
\end{tabular}

Yang et al. [156] performed sequential selective extraction and separation of bio-oil obtained from liquefaction of Salix psammophila using nine different organic solvents with different polarities. The order of solvents for bio-oil extraction yield from high to low: THF $>$ toluene $>$ EAC $>$ acetone $>$ ether $>$ methylene chloride $>$ methanol $>$ petroleum ether $>$ n-hexane. It also investigated the effect of various solvents on extracting mediummolecular compounds (oligomers) from high-valued low-molecular weight chemicals (e.g., 2-cyclopenten-1-one, 2-methyl-, phenol, 2-methoxy-, phenol and 2,6-dimethoxy-, phenol) that can be used directly in industrial applications or to separate oil fractions. The yield of extracted heavy oil varied differently and not linearly with the polarity of solvents [156]. High amounts of ketones, phenolics, and alkoxy phenolics were extracted by highly polar solvents, such as THF, EAC, and acetone. For better analysis of the components of heavy oil fractions, a suggestion was made to extract several fractions of heavy oil using different solvents in a proper sequence of their polarities [156]. A multistep extraction method conducted in this work involves using three organic solvents arranged from high to low polarities (THF, EAC, and n-hexane), where the solvent with lowest polarity was used in the final step to extract light fractions.

Anouti et al. [69] focused on the impact of solvent types on heavy oil quality extracted after the HTL of blackcurrant pomace as a biomass feedstock. EAC, hexane, acetone, and 
isopropyl alcohol were the selected solvents used for extraction. The organic solvents recover heavy oil from solid residue and the remaining solvent is evaporated. The evaporation step resulted in loss of the light volatile fractions with the solvent, thus affecting the composition of heavy oil. Acetone extracted the highest yield of heavy oil compared to the other solvents, which indicates that acetone, which has the highest polarity, was able to produce high yields of heavy oil. However, hexane was found to be an effective solvent to produce high quality heavy oil compared to the other solvents. Thus, the polarity of a solvent plays an important role in bio-oil extraction [69,155].

Along with the extraction solvent, the separation technique also affects the properties of bio-oil. Yang et al. [157] conducted HTL on three different feedstocks (Chlorella sp. (C. sp.), spent coffee grounds (SCG), 50/50 Chlorella sp./spent coffee grounds (C. sp./SCG)) and investigated the effect of different separation techniques and types of solvent on the yield and physicochemical (i.e., chemical composition and dynamic viscosity) properties of heavy oil. Yang [157] suggested using solvents with a wide range of dielectric constants, as a solvent's polarity is closely linked to its dielectric properties. Solvent extraction, Soxhlet filtration, and microwave-assisted extraction methods were used as separation techniques to recover heavy oil. From the results obtained after the extraction procedures, it was found that DCM and THF extracted high yields of heavy oil and hexane gave the lowest yield. Interestingly, acetone, which has the highest dielectric constant (21.0) and a high polarity value (4.3), produced a heavy oil yield lower than that obtained by DCM and THF $[156,157]$. The heavy oil yield was independent of the separation techniques, but filtration was suggested to be the best method to extract heavy oil based on operation costs incurred during the separation process. Furthermore, a change in separation technique did not affect the yield and physical properties of the heavy oil extracted with different solvents, but the type of solvent and feedstock affected the viscosity of the extracted heavy oil [157].

Lu et al. [68] experimented with different solvents (DCM, acetone, MTBE) to understand their effect on the yield and elemental composition of heavy oil recovered from HTL processes on different feedstocks (soybean oil, soy protein, cellulose, xylose, lignin, and quinary mixture). Heavy oil yields derived from soybean oil and soy protein did not vary with different solvents, though acetone was found to produce a high yield of heavy oil during the HTL of feedstocks that were high in cellulose, xylose, and lignin. Lu et al. [68] observed that the yield of heavy oil from the HTL of feedstocks that are rich in saccharides and lignin is greatly affected by what type of solvent is used for extraction. Acetone exhibited the highest yield of heavy oil extracted, whereas DCM produced the lowest yields of heavy oil, which indicates that even solvents such as acetone and DCM with similar polarities produce varying yields of bio-oil. Hence, the polarity of a solvent cannot be the sole determinant in evaluating an extraction solvent's performance. There seems to a strong agreement from Valdez et al. [154], Xu et al. [158], Watson et al. [159], and Lu et al. [68] that solvent type plays a critical role in the yield and chemical composition of heavy oil extracted from HTL products.

Table 13. Effect of extraction solvents on separation of products during HTL.

\begin{tabular}{|c|c|c|c|c|c|c|c|c|c|}
\hline Biomass & $\begin{array}{l}\text { Operation } \\
\text { Conditions }\end{array}$ & $\begin{array}{l}\text { Extraction } \\
\text { Solvent }\end{array}$ & $\underset{(w t \%)}{\text { Oil }}$ & $\begin{array}{l}\text { HHV } \\
\text { (MJ } \\
\left.\mathrm{kg}^{-1}\right)\end{array}$ & $\underset{(w t \%)}{C}$ & $\underset{(w t \%)}{\mathbf{H}}$ & $\underset{(w t \%)}{O}$ & Comments & Ref. \\
\hline \multirow{7}{*}{$\begin{array}{l}\text { Marine } \\
\text { algae }\end{array}$} & \multirow{7}{*}{$\begin{array}{l}\mathrm{T}: 350^{\circ} \mathrm{C} \\
\mathrm{R}: 60 \mathrm{~min}\end{array}$} & Hexadecane & 38.66 & - & - & - & \multirow{7}{*}{-} & \multirow{7}{*}{$\begin{array}{l}\text { DCM and chloroform were found } \\
\text { more effective in extraction of } \\
\text { light ends and fatty acids } \\
\text { derivatives. }\end{array}$} & \multirow{7}{*}{ [154] } \\
\hline & & Decane & 39.39 & - & 68.80 & 9.37 & & & \\
\hline & & Hexane & 31.79 & - & 70.45 & 9.80 & & & \\
\hline & & Cyclohexane & 33.68 & - & 64.87 & 9.76 & & & \\
\hline & & Methoxycyclopentane & 31.91 & - & 72.27 & 9.70 & & & \\
\hline & & Chloroform & 34.75 & - & 73.68 & 9.85 & & & \\
\hline & & DCM & 30.14 & - & 75.76 & 10.57 & & & \\
\hline
\end{tabular}


Table 13. Cont.

\begin{tabular}{|c|c|c|c|c|c|c|c|c|c|}
\hline Biomass & $\begin{array}{l}\text { Operation } \\
\text { Conditions }\end{array}$ & $\begin{array}{l}\text { Extraction } \\
\text { Solvent }\end{array}$ & $\begin{array}{c}\text { Oil } \\
\text { (wt } \%)\end{array}$ & $\begin{array}{l}\text { HHV } \\
(\mathrm{MJ} \\
\left.\mathrm{kg}^{-1}\right)\end{array}$ & $\underset{(w t \%)}{\mathrm{C}}$ & $\underset{(w t \%)}{\mathbf{H}}$ & $\underset{(w t \%)}{O}$ & Comments & Ref. \\
\hline \multirow{9}{*}{$\begin{array}{l}\text { Willow } \\
\text { branches }\end{array}$} & \multirow{9}{*}{$\begin{array}{l}\mathrm{T}: 300^{\circ} \mathrm{C} \\
\mathrm{R}: 30 \mathrm{~min}\end{array}$} & Petroleum ether & 12.95 & - & \multirow{9}{*}{-} & \multirow{9}{*}{-} & \multirow{9}{*}{ - } & \multirow{9}{*}{$\begin{array}{l}\text { Ketones and phenolic compounds } \\
\text { were easily extracted with high } \\
\text { polarity solvents such as THF, } \\
\text { EAC, acetone, and methanol. } \\
\text { Multistep-extraction procedure } \\
\text { provided efficient separation of } \\
\text { bio-oil components and } \\
\text { sequential analysis of } \\
\text { components. }\end{array}$} & \multirow{9}{*}{ [156] } \\
\hline & & n-hexane & 8.27 & - & & & & & \\
\hline & & Toluene & 38.31 & - & & & & & \\
\hline & & Ether & 28.10 & - & & & & & \\
\hline & & DCM & 26.78 & - & & & & & \\
\hline & & THF & 45.34 & - & & & & & \\
\hline & & EAC & 30.55 & - & & & & & \\
\hline & & Acetone & 30.00 & - & & & & & \\
\hline & & Methanol & 23.32 & - & & & & & \\
\hline \multirow{4}{*}{$\begin{array}{l}\text { Blackcurrant } \\
\text { pomace }\end{array}$} & \multirow{4}{*}{$\begin{array}{l}\text { T: } 300^{\circ} \mathrm{C} \\
\text { R: } 60 \mathrm{~min}\end{array}$} & EAC & $28 \pm 3$ & 33.4 & $75 \pm 1$ & \multirow{4}{*}{-} & \multirow{4}{*}{-} & \multirow{4}{*}{$\begin{array}{l}\text { Heavy oil extracted using hexane } \\
\text { resulted in having high quality } \\
\text { with high C-content and HHV. }\end{array}$} & \multirow{4}{*}{ [69] } \\
\hline & & Hexane & $17 \pm 3$ & 38.4 & $80 \pm 1$ & & & & \\
\hline & & Acetone & $32 \pm 3$ & 35.0 & $74 \pm 1$ & & & & \\
\hline & & Isopropyl alcohol & $29 \pm 3$ & 34.6 & $73 \pm 1$ & & & & \\
\hline \multirow{10}{*}{ Duckweed } & \multirow{10}{*}{$\begin{array}{l}\mathrm{T}: 350^{\circ} \mathrm{C} \\
\mathrm{R}: 30 \mathrm{~min}\end{array}$} & Isopropanol & $26 \pm 1$ & $34 \pm 2$ & $70 \pm 0.7$ & $9 \pm 0.5$ & $14 \pm 0.7$ & \multirow{10}{*}{$\begin{array}{l}\text { Highest yield of heavy oil was } \\
\text { produced by using isopropanol as } \\
\text { the extraction solvent. } \\
\text { Isopropanol was found to be } \\
\text { miscible with water, and hence } \\
\text { only one phase was separated } \\
\text { since water-soluble products did } \\
\text { not create a separate phase. } \\
\text { Carbon disulfide being a } \\
\text { non-polar solvent was able to } \\
\text { extract high yields of heavy oil } \\
\text { when compared to those } \\
\text { extracted by n-hexane, } \\
\text { cyclohexane, and petroleum ether. }\end{array}$} & \multirow{10}{*}{ [155] } \\
\hline & & Dichloroethane & $19 \pm 1$ & $36 \pm 2$ & $74 \pm 0.7$ & $9 \pm 0.4$ & $10 \pm 0.5$ & & \\
\hline & & DCM & $24 \pm 1$ & $37 \pm 2$ & $76 \pm 0.8$ & $9 \pm 0.4$ & $8 \pm 0.4$ & & \\
\hline & & EAC & $20 \pm 1$ & $37 \pm 2$ & $76 \pm 0.8$ & $9 \pm 0.4$ & $8 \pm 0.4$ & & \\
\hline & & DEE & $17 \pm 0.8$ & $37 \pm 2$ & $76 \pm 0.8$ & $9 \pm 0.5$ & $8 \pm 0.4$ & & \\
\hline & & Benzene & $18 \pm 0.9$ & $38 \pm 2$ & $77 \pm 0.8$ & $9 \pm 0.5$ & $7 \pm 0.4$ & & \\
\hline & & Carbon disulfide & $17 \pm 0.9$ & $38 \pm 2$ & $76 \pm 0.8$ & $9 \pm 0.5$ & $7 \pm 0.3$ & & \\
\hline & & n-Hexane & $3 \pm 0.2$ & $40 \pm 2$ & $78 \pm 0.8$ & $10 \pm 0.5$ & $6 \pm 0.3$ & & \\
\hline & & Cyclohexane & $9 \pm 0.4$ & $39 \pm 2$ & $78 \pm 0.8$ & $10 \pm 0.5$ & $7 \pm 0.3$ & & \\
\hline & & Petroleum ether & $4 \pm 0.2$ & $40 \pm 2$ & $78 \pm 0.8$ & $10 \pm 0.5$ & $6 \pm 0.3$ & & \\
\hline \multirow{2}{*}{ Microalgae } & $\begin{array}{l}\mathrm{T}: 400^{\circ} \mathrm{C} \\
\mathrm{R}: 60 \mathrm{~min}\end{array}$ & $\mathrm{DCM}$ & $29.5 \pm 2.1$ & - & \multirow{2}{*}{ - } & \multirow{2}{*}{-} & \multirow{2}{*}{ - } & \multirow{2}{*}{$\begin{array}{l}\text { Heavy oil yield increased when } \\
\text { DCM was used as an extraction } \\
\text { solvent. HHV of heavy oil } \\
\text { extracted by either DCM or MTBE } \\
\text { did not have a major difference. }\end{array}$} & \multirow{2}{*}[160]{} \\
\hline & $\begin{array}{l}\mathrm{T}: 400^{\circ} \mathrm{C} \\
\mathrm{R}: 60 \mathrm{~min}\end{array}$ & MTBE & $24.5 \pm 2.3$ & - & & & & & \\
\hline & & Acetone & 28.22 & 35.5 & $70.0 \pm 1.8$ & $10.5 \pm 0.3$ & 17.8 & $\begin{array}{l}\text { Acetone-extracted heavy oil } \\
\text { shows high } \mathrm{N} \text { and } \mathrm{S} \text { content from }\end{array}$ & \\
\hline Chlorella sp. & $\begin{array}{l}\text { T: } 260^{\circ} \mathrm{C} \\
\text { R: } 60 \mathrm{~min}\end{array}$ & DCM & 48.70 & 39.5 & $74.6 \pm 0.2$ & $11.6 \pm 0.1$ & 13.1 & $\begin{array}{l}\text { and high-ash content biomass. } \\
\text { DCM and toluene-extracted }\end{array}$ & [159] \\
\hline & & Toluene & 28.60 & 37.4 & $72.0 \pm 0.8$ & $11.2 \pm 0.1$ & 16.0 & $\begin{array}{l}\text { content from liquefaction of } \\
\text { high-protein content biomass. }\end{array}$ & \\
\hline & & Hexane & $15.2 \pm 1.0$ & & & & & $\begin{array}{l}\text { DCM, THF, and acetone were } \\
\text { effective solvents for extraction, }\end{array}$ & \\
\hline $\begin{array}{l}\text { Spent coffee } \\
\text { grounds }\end{array}$ & $\begin{array}{l}\text { T: } 290^{\circ} \mathrm{C} \\
\text { R: } 10 \mathrm{~min}\end{array}$ & Acetone & $32.3 \pm 1.0$ & & & & & $\begin{array}{l}\text { when compared to hexane. } \\
\text { Hexane was an effective solvent } \\
\text { during Soxhlet separation method }\end{array}$ & [157] \\
\hline & & DCM & $32.8 \pm 1.2$ & & & & & $\begin{array}{l}\text { and was able to recover more heavy } \\
\text { oil when compared to the rest three } \\
\text { solvents. Yield of heavy oil }\end{array}$ & \\
\hline & & THF & $38.1 \pm 2.2$ & & & & & $\begin{array}{l}\text { extracted by filtration is mentioned } \\
\text { here since filtration was the most } \\
\text { efficient separation method. }\end{array}$ & \\
\hline & & DCM & 4.40 & 32.3 & 72.8 & 6.8 & 20.1 & Individual feedstock containing & \\
\hline Cellulose & & Acetone & 10.92 & 30.2 & 70.8 & 6.3 & 25.3 & $\begin{array}{l}\text { cellulose, xylose, and lignin in } \\
\text { high amounts, showed that the }\end{array}$ & \\
\hline & & MTBE & 5.71 & 32.8 & 71.6 & 7.6 & 21.4 & heavy oil extracted did not & \\
\hline Xylose & $\mathrm{T}: 350^{\circ} \mathrm{C}$ & DCM & 6.36 & 31.9 & 73.2 & 6.5 & 20.2 & $\begin{array}{l}\text { depend on solvent type. } \\
\text { It is difficult to achieve the high }\end{array}$ & {$[68]$} \\
\hline кyrose & $\mathrm{R}: 30 \mathrm{~min}$ & Acetone & 10.52 & 30.2 & 70.1 & 6.3 & 23.4 & yields and high HHV from heavy & {$[00]$} \\
\hline & & MTBE & 8.15 & 32.4 & 71.6 & 7.3 & 21.8 & oil extracted by a certain & \\
\hline & & DCM & 1.22 & 32.1 & 70.1 & 7.5 & 22.1 & & \\
\hline Lignin & & Acetone & 14.35 & 17.9 & 46.8 & 5.4 & 46.3 & & \\
\hline & & MTBE & 2.77 & 19.9 & 51.7 & 5.2 & 41.2 & & \\
\hline
\end{tabular}

EAC: ethyl acetate, DCM: dichloromethane, MTBE: methyl tert-butyl ether, THF: tetrahydrofuran, IPA: isopropyl alcohol, DEE: diethyl ether. 


\section{HTL Products and Applications}

\subsection{Bio-Oil}

Bio-crude/bio-oil or heavy oil produced from the HTL process is a brown to dark brown, highly viscous liquid with a high carbon, low oxygen content and an overall high HHV value ranging from 25 to $40 \mathrm{MJ} \mathrm{kg}^{-1}$. Bio-oil is a mixture of complex chemical compounds, which includes ketones, aldehydes, phenolics, phenyl derivatives, fatty acids, esters, fatty acid alky esters, alcohols, polyols, unsaturated hydrocarbons, and saturated hydrocarbons and some fraction of nitrogenous compounds such as amine and amides [24,161]. The biomass degradation, route of conversion, intermediate formation, and interaction, and the rate kinetics are decided with respect to the process parameters and solvent type as discussed in Sections 2 and 3. All these factors affect the bio-oil yield, chemical composition, and physical properties, such as viscosity and total acid number value.

In the modern economy, more and more attention has been focused on sustainable fuels and chemicals. Bio-oil has a huge potential to meet these requirements. When compared with conventional fuels such as gasoline and diesel, bio-oil has a high total acid number (TAN), viscosity and water content $[69,79,162]$. Taghipour et al. [163] has summarized the properties of crude bio-oil obtained from various sources. Because crude bio-oil has a higher TAN number, it is very corrosive in nature due to which it is difficult to store and operate on crude bio-oil. Its increased viscosity also increases the challenges associated with transporting bio-oil. Its high-water content reduces its total combustion energy. Without definite properties, it becomes increasingly challenging to use bio-oil on existing boilers and/or gasifiers. Hence, to substitute conventional fuels with bio-oil, one possible application in this field is bio-oil upgrading and separation to obtain different classes of fuels from complex crude bio-oil mixtures.

Taghipour et al. [163] reviewed literature on the fractional distillation of crude bio-oil and presented a detailed description of the potential application of distillates of bio-oil. They also discussed about the effect of distillation on chemical composition, heating value, viscosity, density, water content, miscibility, storage, and stability. Pedersen et al. [164] performed fractional distillation of bio-crude obtained from HTL and found six distillate fractions and distillate residue; the lighter distillate fraction was comprised of light oxygenates, which can be a potential option to produce useful chemicals. A mixture of ketones was obtained, which can act as a precursor for liquid transport fuels. The bio-oil can also be used to produce other higher value fuels such as jet fuel, gasoline, diesel, and hydrogen-rich gas. Tzanetis et al. [165] developed a method to produce jet fuel from bio-crude. First, crude bio-oil was upgraded through hydrotreatment to reduce the oxygen content, producing hydrogen-rich gas, a mixture of jet fuel, gasoline, diesel, and heavy oil, along with a waste aqueous stream. Next, fractional distillation was performed to obtain individual fractions. The $\mathrm{H}_{2}$-rich gas obtained in first step was used recirculated in the upgrading process. Apart from developing useful fuels, bio-oil can also be used to synthesis many other industrial chemicals [166-169].

\subsection{Aqueous Phase}

The aqueous phase is formed as a secondary product in a batch process and as a side stream of process water in a continuous operation. With an advancement in the field of HTL and the shift of focus from batch to the development of a continuous operation, there is an increasing need to advance our understanding of the aqueous phase to make the overall process more viable. Approximately $25 \%$ to $50 \%$ of the carbon present in biomass can end up in an aqueous phase [170]. This also highlights the need to develop techniques and methodology to understand the properties and composition of the aqueous phase.

The aqueous phase mainly comprises low molecular-weight organic acids and polyols, a moderate fraction of phenolic compounds and ketones, and a small amount of sugar. The major fraction acid accounts for $40 \%-50 \%$ of the weight of the aqueous phase and is mainly a mixture of acetic acid, lactic acid, glycolic acid, propionic acid, formic acid, butanoic 
acid, pentenoic acid, and butenedioic acid. The alcohols and polyols mainly consist of methanol, glycol, ethylene glycol, propylene glycol, catechol, glycerol, D-glucitol, xylitol, and ribitol $[27,170]$.

The large quantity of the aqueous phase produced in HTL raises a concern about the economic efficiency of the process and its use. Using the aqueous phase for recirculation as a solvent in a continuous operation and using the aqueous phase for the next HTL run in a batch cycle can significantly help to utilize it. The use of aqueous phase for recirculation also has potential benefits for the yield and quality enhancement of bio-oil and hydrochar. It reduces the requirement for process water treatment and limits the consumption of fresh water. When Zhu et al. [23] recirculated the aqueous phase during the HTL of barley straw, the result was an increase in the yield of bio-oil from $34.9 \mathrm{wt} \%$ to $38.4 \mathrm{wt} \%$ after three runs. This increase was associated with the presence of organics in the aqueous phase, which accelerated the overall decomposition of the biomass. Biller et al. [171] also investigated the effect of aqueous phase recirculation on the HTL of dry distillers' grain in the presence of $\mathrm{K}_{2} \mathrm{CO}_{3}$ and observed an increase in bio-oil yield from $44.3 \%$ to $60 \%$ after the first recirculation. The yield of solid residue also increased from $1.2 \%$ to $14 \%$ after the seventh recirculation run.

Many studies suggested other possible options such as the catalytic cracking of the aqueous phase product to obtain valuable chemicals such as olefins and aromatic hydrocarbons such as benzene, toluene, and xylene. Miyata et al. [172] developed a method to separate the light water-soluble fraction (by freeze drying) and heavy water-soluble fraction (by water removal) and conducted catalytic cracking on separated fractions, producing an olefins + BTX yield of $49 \%$ and $14 \%$, respectively.

Another less researched application for the aqueous phase is catalytic hydrothermal gasification to produce fuel gas, which mainly consists of $\mathrm{CO}_{2}, \mathrm{CH}_{4}$, and $\mathrm{H}_{2}[10,173]$. The idea of a catalytic supercritical hydrothermal gasification of the aqueous phase from the HTL of microalgae biomass to produce $\mathrm{H}_{2}$-rich gas can also be applied for the aqueous phase generated during the HTL of lignocellulosic biomass [174]. Even though there is a lot of potential, more knowledge is needed before we can aptly implement the aqueous phase.

\subsection{Char}

During hydrothermal liquefaction, the main product obtained is bio-oil, whereas in hydrothermal carbonization the main product is char. The solid by-product obtained using HTL is known as either solid residue, residue, char, biochar, or hydrochar. The yield of char depends greatly on the type and composition of biomass. The yield may range anywhere from $\sim 5-60 \mathrm{wt} \%[27,73,82,96,114]$. Biomass with a high lignin content tends to produce more char than one with more cellulose and hemicellulose. Demirbas et al. [175] investigated the effect of lignin content on oil and char yield and found that biomass with a high lignin content in the range of $41-48 \mathrm{wt} \%$ produced a solid residue of $40-50 \mathrm{wt} \%$, whereas the one with a low lignin content of about 14-27 wt\% (cellulose: $45-50 \mathrm{wt} \%$ ) provided a solid residue yield of $21-26 \mathrm{wt} \%$.

The yield of char and its chemical composition significantly depend on the process parameters, such as temperature, pressure, retention time, biomass-to-solvent ratio, and type and concentration of catalyst. The char contains a high $\mathrm{C}$ and $\mathrm{H}$, low $\mathrm{O}$, and high HHV value compared with biomass. For the solid residue obtained from lignocellulosic biomass, the $\mathrm{C} \mathrm{wt}_{\mathrm{t}} \%$ ranges from $55-78 \mathrm{wt} \%$, the $\mathrm{H} \mathrm{wt} \%$ ranges from $4-6 \mathrm{wt} \%$ and the oxygen content ranges from $15-35 \mathrm{wt} \%[176,177]$. It is also observed that the percentage of nitrogen is more in solid residue when compared to biomass $[7,178]$.

The char from the HTL has very promising qualities, which are encouraging for its application in the energy sector, soil enhancement and as an adsorbent. The char tends to have a high hydrophobicity; it allows easy handling and storage since it poses a higher resistance to humidity [176]. The char can have both a positive and negative effect on soil fertility. It is required to go through some pre-treatment in order to reduce its negative effect on plant growth [179]. It can have varied mineral and organic contents based on 
biomass sources. These contents can include a high C:N ratio and low mineral-N or low C:N ratio and high mineral- $\mathrm{N}$, as well as many other minerals. It is important to investigate the char ratio with fertilizer so that a proper intake can take place in the plant for growth and so that no additional $\mathrm{N}$ is left behind to emit toxic chemicals [179-181].

The char obtained from the HTL process has a high calorific value and can be used for energy applications such as direct combustion or co-combustion with coal or it can be used to prepare energy storage materials such as bio-batteries, fuel cells, and biocapacitors $[79,120,182,183]$. The hydrochar obtained from HTL shows a significant reduction in ash content when compared to char from other processes and biomass. The inorganic minerals such as $\mathrm{Ca}, \mathrm{Si}, \mathrm{Na}, \mathrm{K}, \mathrm{Mg}, \mathrm{P}, \mathrm{Fe}$, and $\mathrm{Mn}$ are mostly present in hemicellulose and are leached out in a hot compressed solvent. This makes hydrochar a cleaner fuel by eradicating the negatives that cause fouling, corrosion, scaling, and slagging, and promote toxicity in water and air during combustion [184,185].

The char can also be used as an adsorbent to remove pollutants such as heavy metals and organic materials from flue gas, water, and wastewater. Liu et al. [178] studied the characteristic properties of char obtained from the HTL of pinewood and rice husks and experimented to determine if they could be used to remove lead from an aqueous solution. It was observed that more irregular surfaces and oxygen-containing functional groups were developed on the char. The maximum lead adsorption capacity was 2.40 to $4.25 \mathrm{mg} / \mathrm{g}$ for rice husks and pinewood char, respectively. In brief, char has high energy density and better qualities than biomass for various applications, but to use it with present technology, more quality work is needed to make sure it meets environmental standards and to better understand the life cycle assessment.

\subsection{Gases}

Gas products also one of the by-products obtained in the HTL process. Due to the poor gas composition in the process, as shown in Table 14, and because bio-oil is considered more important, gas is either not analyzed or included with other products $[27,98,186]$. In general, the gas fraction accounts for $5-15 \mathrm{wt} \%\left(\mathrm{~T}: 250-375{ }^{\circ} \mathrm{C}\right.$ ) of the total product distribution from HTL [70,81]. The yield of gases is greatly enhanced with temperatures near and above the critical point of water. Alba et al. [73] investigated the liquefaction of microalgae over a temperature range of $175-450{ }^{\circ} \mathrm{C}$ and observed that the yield of gas was negligible near $200{ }^{\circ} \mathrm{C}$ and $15 \%$ at $300{ }^{\circ} \mathrm{C}$, which increased significantly as the temperature crossed $375{ }^{\circ} \mathrm{C}(24 \%)$ and reached a value of $47.4 \%$ at $450{ }^{\circ} \mathrm{C}$ while all other product fractions kept decreasing. Many other studies observed similar trends for the gas yield near the supercritical condition $[24,78,97]$. Furthermore, an increase in retention time at subcritical and supercritical temperatures increased the gas yield. One possible reason for the increase in the gas fraction is the increased cracking of oil and char. Yang et al. [97] and Brand et al. [98] observed that a fraction of $\mathrm{CO}_{2}$ dominates in gas up to $300-325^{\circ} \mathrm{C}$ but on a further increase in temperature, the $\mathrm{CO}$ starts to dominate, followed by $\mathrm{CO}_{2}$. Other compounds observed in gas were $\mathrm{H}_{2}$, short chain alkenes, and alkanes $\left(\mathrm{CH}_{4}, \mathrm{C}_{2} \mathrm{H}_{6}, \mathrm{C}_{3} \mathrm{H}_{8}\right.$, $\mathrm{C}_{2} \mathrm{H}_{4}$ ), but the amounts are negligible. Isa et al. [78] studied the conversion of miscanthus in anhydrous state and in the presence of supercritical water media and observed an increase in the $\mathrm{C}_{\mathrm{i}}(\mathrm{i}=1-4)$ yield from $1.9 \mathrm{wt} \%$ (anhydrous) to $2.44 \mathrm{wt} \%$ (supercritical water). A similar increase was observed in the total yield of $\mathrm{H}_{2}, \mathrm{CO}$, and $\mathrm{CO}_{2}$ from $24.3 \mathrm{wt} \%$ (anhydrous) to $30.3 \mathrm{wt} \%$ (supercritical water). It was also observed that the increased water content in the reactor decreased the CO fraction from $3.9 \mathrm{wt} \%$ (anhydrous) to $0.3 \mathrm{wt} \%$ (supercritical water). 
Table 14. Various gas compositions obtained from the HTL process.

\begin{tabular}{|c|c|c|c|c|}
\hline Biomass & Gas Yield (wt\%) & Composition & Comments & Ref. \\
\hline Birch wood & $1-12$ & $\begin{array}{l}\mathrm{CO}_{2}, \mathrm{CO}, \mathrm{C}_{2} \mathrm{H}_{4} \\
\mathrm{C}_{2} \mathrm{H}_{6}, \mathrm{C}_{3} \mathrm{H}_{8}\end{array}$ & $\begin{array}{c}\mathrm{CO}_{2} \text { dominates near } 300^{\circ} \mathrm{C} \text {, and } \mathrm{CO} \text { starts to } \\
\text { dominate over } 325^{\circ} \mathrm{C} \text {. } \\
\text { Fraction of methane increases significantly } \\
\text { above } 350^{\circ} \mathrm{C} \text {. }\end{array}$ & [97] \\
\hline $\begin{array}{l}\text { Wet and Dry distiller's } \\
\text { grains and solubles }\end{array}$ & $\sim 15 \%$ & $\begin{array}{l}\mathrm{CO}_{2}, \mathrm{H}_{2}, \mathrm{~N}_{2}, \mathrm{CO}, \mathrm{CH}_{4} \\
\text { light alkanes and alkenes }\end{array}$ & $96 \%$ of the gas was $\mathrm{CO}_{2}$ and $1.6 \% \mathrm{H}_{2}$. & [59] \\
\hline Red pine sawdust & $0.2-8.7(\mathrm{~mol} \%)$ & $\begin{array}{l}\mathrm{CO}_{2}, \mathrm{H}_{2}, \mathrm{CO}, \mathrm{CH}_{4}, \mathrm{C}_{2} \mathrm{H}_{6} \\
\mathrm{C}_{2} \mathrm{H}_{4}, \mathrm{C}_{3}-\mathrm{C}_{6} \text { (negligible) }\end{array}$ & $\begin{array}{l}\text { General trend of gas fraction } \mathrm{CO}>\mathrm{CO}_{2}> \\
\qquad \mathrm{C}_{2} \mathrm{H}_{4}>\mathrm{CH}_{4}>\mathrm{C}_{2} \mathrm{H}_{6} \text {. } \\
\text { The amount of } \mathrm{H}_{2} \text { and } \mathrm{C}_{3}-\mathrm{C}_{6} \text { was negligible. } \\
\text { At } 400{ }^{\circ} \mathrm{C} \text {, compounds like } \mathrm{C}_{2}-\mathrm{C}_{6} \text { were } \\
\text { also present. }\end{array}$ & [98] \\
\hline Miscanthus & $\sim 20-37$ & $\begin{array}{l}\mathrm{CO}_{2}, \mathrm{CO}, \mathrm{CH}_{4}, \mathrm{H}_{2} \\
\mathrm{C}_{2} \mathrm{H}_{4}, \mathrm{C}_{2} \mathrm{H}_{6}, \mathrm{C}_{3} \mathrm{H}_{6} \\
\mathrm{C}_{3} \mathrm{H}_{8}, \mathrm{C}_{4} \mathrm{H}_{10}\end{array}$ & $\begin{array}{l}\text { CO diminished with increase in water ratio in } \\
\text { the reactor. }\end{array}$ & [78] \\
\hline Corn straw & 16.5 & \multicolumn{2}{|c|}{$\mathrm{H}_{2}(1.9 \%), \mathrm{CO}(6.2 \%), \mathrm{CH}_{4}(0.9 \%), \mathrm{CO}_{2}(90.8 \%), \mathrm{C}_{2} \mathrm{H}_{6}(0.2 \%), \mathrm{C}_{2} \mathrm{H}_{8}(0.1 \%)$} & \\
\hline Peanut straw & 19.9 & \multicolumn{2}{|c|}{$\mathrm{H}_{2}(2.7 \%), \mathrm{CO}(4.2 \%), \mathrm{CH}_{4}(1.1 \%), \mathrm{CO}_{2}(91.6 \%), \mathrm{C}_{2} \mathrm{H}_{6}(0.1 \%), \mathrm{C}_{2} \mathrm{H}_{8}(0.2 \%)$} & [23] \\
\hline Soybean straw & 19.7 & \multicolumn{2}{|c|}{$\mathrm{H}_{2}(3.1 \%), \mathrm{CO}(5.5 \%), \mathrm{CH}_{4}(0.6 \%), \mathrm{CO}_{2}(90.6 \%), \mathrm{C}_{2} \mathrm{H}_{6}(0.1 \%), \mathrm{C}_{2} \mathrm{H}_{8}(0.1 \%)$} & \\
\hline Rice straw & 22.9 & \multicolumn{2}{|c|}{$\mathrm{H}_{2}(2.2 \%), \mathrm{CO}(6.2 \%), \mathrm{CH}_{4}(1.1 \%), \mathrm{CO}_{2}(90.2 \%), \mathrm{C}_{2} \mathrm{H}_{6}(0.1 \%), \mathrm{C}_{2} \mathrm{H}_{8}(2.2 \%)$} & \\
\hline
\end{tabular}

$\mathrm{CO}_{2}$ and $\mathrm{CO}$ are mainly formed by the decomposition of oxygen-containing groups in the lignocellulosic biomass through decarboxylation and decarbonylation reactions. $\mathrm{CH}_{4}$ is formed via the decomposition of a methoxy group whereas other short-chain hydrocarbons $\left(C_{2}-C_{3}\right)$ are formed during the cracking of long-chain hydrocarbons and aromatics [98]. Some researchers did focus on the quantification and composition analysis of the gas phase on a lab scale model. However, only limited data are available on the gas phase applicability and potential for a large-scale operation. Future works can aim to clarify how gas yield and composition vary when operations are scaled, and how to separate and increase light hydrocarbon fractions from obtained gases.

\section{Conclusions}

Currently, biomass-derived fuels seem to provide a viable solution to the search for alternative and renewable fuel sources. HTL is one of the many available approaches to convert biomass into biofuels.

- A suitable range of temperatures for the HTL of agricultural and forest-based residues is $275-325^{\circ} \mathrm{C}$ and the choice of a final temperature strongly varies with the feedstock composition. A lower final temperature results in an incomplete conversion, whereas a temperature above $350{ }^{\circ} \mathrm{C}$ promotes carbonization and cracking, leading to an increased char and gas yield.

- Water enhances the decomposition of cellulose, hemicellulose, and to some extent, lignin. The organic solvents help in degradation of lignin. The synergistic effect of using an organic solvent-water mixture during HTL improves the overall liquefaction process.

- In the presence of extraction solvents, many macromolecular oligomers are dissolved, leading to the formation of new compounds and high-value chemicals.

- The catalysts are important to trigger earlier and faster biomass degradation by activating the kinetics of primary reactions, hindering secondary reactions, such as repolymerization and cracking, and reducing dependency on other parameters, such as pressure, temperature, and retention time. 
- Undoubtedly, alkali metals are the most effective at easing the degradation of biomass because they disrupt the physical barrier in the biomass. More generally, $\mathrm{K}_{2} \mathrm{CO}_{3}$ is a first-rate choice for a catalyst.

- $\quad$ Pressure is important to maintain a single-phase liquid slurry of the feed material so that the reaction can proceed smoothly. In the subcritical temperature range, pressure has some effect on the bio-oil yield, whereas at supercritical conditions, even a pressure of 30-40 MPa is inadequate to affect hydrolysis and the oil yield.

- The choice of retention time is subject to parameters, such as temperature, heating rate, and catalyst. A short retention time can lead to the partial decomposition of biomass, whereas a long retention time can encourage the repolymerization and cracking of oil into char and gas.

Much progress has been made on the HTL process. The capability of the HTL process to convert biomass to produce high-energy biofuels has been proven without question. As it stands, more research is needed on the pilot scale facilities, optimization of parameters for a continuous process, understanding the physical properties of oil and, most importantly, developing more robust upgrading and distillation techniques.

\section{Challenges and Future Scope}

In last two decades, HTL has more than proved that it is a highly efficient was to convert biomass to biofuels and value-added chemicals. Compared to other biomass conversion technologies, such as pyrolysis and gasification, HTL is reasonably new. The technology must overcome many challenges at both the experimental and theoretical stages, which leads to a range of future research possibilities.

- Some feeds with low overall conversion and poor bio-oil yield during HTL show very promising results in the presence of another class of feedstocks. The research on co-liquefaction is sparse; thus, more can be done to examine the co-liquefaction of two or more feedstocks to improve the understanding of their synergistic effect on bio-oil yield.

- The heating value of bio-oil is low compared to that of conventional liquid fuels, which limits its applications. The low heating value is directly related to the high oxygen content. Hence, there is a need to develop new methodology and techniques to upgrade the bio-oil produced from HTL.

- Both bio-oil and char obtained from HTL contain a significant portion of heterogeneous compounds with nitrogenous impurities. A study can focus on understanding the reaction pathways of major impurities, such as nitrogen, to clarify its biodegradability and toxicity.

- Apart from the experimental section, not enough research has been conducted on the theoretical aspects of the HTL process:

- Establishing a correlation for similar types of feedstocks by doing regression analysis.

- Developing simulation models using computation fluid dynamics to develop more insight into the effect of the physical properties of biomass water slurry and the effect of various parameters in a continuous pilot scale process.

- Utilizing the concept of molecular dynamic simulations to develop a more cohesive understanding on the reaction pathways; such investigations are warranted.

- Understanding the techno-economic analysis of commercializing the HTL process and extending it from production all the way through to distillation. A life cycle assessment of the process is further suggested.

- More robust understanding about co-processing of bio-oil can be acquired using detailed aspen models on the distillation process. 
Author Contributions: Writing-original draft preparation, A.M. and S.D.; formal analysis, A.M.; data curation: A.M.; writing-review and editing, A.M., D.P., M.K. and R.G.; resources, D.P. and M.K.; supervision, D.P., M.K., A.K. and R.G.; funding acquisition, A.K. and R.G. All authors have read and agreed to the published version of the manuscript.

Funding: This research received no external funding.

Acknowledgments: The authors thank the Future Energy System-Canada First Research Fund, University of Alberta, Edmonton, Canada for supporting this study.

Conflicts of Interest: The authors declare no conflict of interest.

\section{References}

1. Pudasainee, D.; Kurian, V.; Gupta, R. Application Status of Post-Combustion $\mathrm{CO}_{2}$ Capture; Royal Society of Chemistry (RSC): London, UK, 2018; pp. 259-289. [CrossRef]

2. Cao, L.; Zhang, C.; Chen, H.; Tsang, D.; Luo, G.; Zhang, S.; Chen, J. Hydrothermal Liquefaction of Agricultural and Forestry Wastes: State-of-the-Art Review and Future Prospects. Bioresour. Technol. 2017, 245, 1184-1193. [CrossRef] [PubMed]

3. Kumar, M.; Oyedun, A.O.; Kumar, A. A Review on the Current Status of Various Hydrothermal Technologies on Biomass Feedstock. Renew. Sustain. Energy Rev. 2018, 81, 1742-1770. [CrossRef]

4. Basu, P. Introduction. Biomass Gasif. Pyrolysis Torrefaction 2013, 2013, 1-27. [CrossRef]

5. Vaezi, M.; Kumar, A. Development of Correlations for the Flow of Agricultural Residues as Slurries in Pipes for Bio-Refining. Biosyst. Eng. 2014, 127, 144-158. [CrossRef]

6. Basu, P. 3.6.2 Proximate Analysis. In Biomass Gasification, Pyrolysis and Torrefaction: Practical Design and Theory; Elsevier: Amsterdam, The Netherlands, 2013.

7. Xiao, L.-P.; Shi, Z.-J.; Xu, F.; Sun, R.-C. Hydrothermal Carbonization of Lignocellulosic Biomass. Bioresour. Technol. 2012, 118, 619-623. [CrossRef]

8. Liu, Q.; Xu, R.; Yan, C.; Han, L.; Lei, H.; Ruan, R.; Zhang, X. Bioresource Technology Fast Hydrothermal Co-Liquefaction of Corn Stover and Cow Manure for Biocrude and Hydrochar Production. Bioresour. Technol. 2021, 340, 125630. [CrossRef] [PubMed]

9. Sharma, K.; Shah, A.; Toor, S.; Seehar, T.; Pedersen, T.; Rosendahl, L. Co-Hydrothermal Liquefaction of Lignocellulosic Biomass in Supercritical Water. Energies 2021, 14, 1708. [CrossRef]

10. Elliott, D.; Biller, P.; Ross, A.B.; Schmidt, A.J.; Jones, S.B. Hydrothermal Liquefaction of Biomass: Developments from Batch to Continuous Process. Bioresour. Technol. 2015, 178, 147-156. [CrossRef] [PubMed]

11. Krylova, A.Y.; Zaitchenko, V.M. Hydrothermal Carbonization of Biomass: A Review. Solid Fuel Chem. 2018, 52, 91-103. [CrossRef]

12. Jain, A.; Balasubramanian, R.; Srinivasan, M. Hydrothermal Conversion of Biomass Waste to Activated Carbon with High Porosity: A Review. Chem. Eng. J. 2016, 283, 789-805. [CrossRef]

13. Funke, A.; Ziegler, F. Hydrothermal Carbonization of Biomass: A Summary and Discussion of Chemical Mechanisms for Process Engineering. Biofuels Bioprod. Biorefining 2010, 4, 160-177. [CrossRef]

14. Mathanker, A. Hydrothermal Liquefaction of Lignocellulosic Biomass to Produce Biofuels. Master's Thesis. 2020. Available online: https: / / era.library.ualberta.ca/items/ff551bc6-9676-4108-a098-ca315250fa24 (accessed on 1 July 2021). [CrossRef]

15. Zhu, Z.; Toor, S.S.; Rosendahl, L.; Yu, D.; Chen, G. Influence of Alkali Catalyst on Product Yield and Properties via Hydrothermal Liquefaction of Barley Straw. Energy 2015, 80, 284-292. [CrossRef]

16. Elliott, D.C. Catalytic Hydrothermal Gasification of Biomass. Biofuels Bioprod. Biorefining 2008, 2, 254-265. [CrossRef]

17. Matsumura, Y. Hydrothermal Gasification of Biomass. Recent Adv. Chem. Convers. Biomass 2015, 2015, 251-267. [CrossRef]

18. Azadi, P.; Syed, K.; Farnood, R. Catalytic Gasification of Biomass Model Compound in Near-Critical Water. Appl. Catal. A Gen. 2009, 358, 65-72. [CrossRef]

19. Gollakota, A.; Kishore, N.; Gu, S. A Review on Hydrothermal Liquefaction of Biomass. Renew. Sustain. Energy Rev. 2018, 81, 1378-1392. [CrossRef]

20. De Jong, W.; Van Ommen, J.R. Biomass As a Sustainable Energy Source for the Future. In Biomass as a Sustainable Energy Source for the Future; Wiley: Hoboken, NJ, USA, 2014; Volume 9781118304, pp. 1-582. [CrossRef]

21. Tursi, A. A Review on Biomass: Importance, Chemistry, Classification, and Conversion. Biofuel Res. J. 2019, 6, 962-979. [CrossRef]

22. Rowell, R.M.; Peterssen, R.; Han, J.S. Cell Wall Chemistry. In Handbook of Wood Chemistry and Wood Composites; Routledge: Oxfordshire, UK, 2005.

23. Tian, Y.; Wang, F.; Djandja, J.O.; Zhang, S.-L.; Xu, Y.-P.; Duan, P.-G. Hydrothermal Liquefaction of Crop Straws: Effect of Feedstock Composition. Fuel 2020, 265, 116946. [CrossRef]

24. Mathanker, A.; Pudasainee, D.; Kumar, A.; Gupta, R. Hydrothermal Liquefaction of Lignocellulosic Biomass Feedstock to Produce Biofuels: Parametric Study and Products Characterization. Fuel 2020, 271, 117534. [CrossRef]

25. Patel, M.; Oyedun, A.O.; Kumar, A.; Gupta, R. What Is the Production Cost of Renewable Diesel from Woody Biomass and Agricultural Residue Based on Experimentation? A Comparative Assessment. Fuel Process. Technol. 2019, 191, 79-92. [CrossRef]

26. Younas, R.; Hao, S.; Zhang, L.; Zhang, S. Hydrothermal Liquefaction of Rice Straw with NiO Nanocatalyst for Bio-Oil Production. Renew. Energy 2017, 113, 532-545. [CrossRef] 
27. Zhu, Z.; Rosendahl, L.; Toor, S.S.; Yu, D.; Chen, G. Hydrothermal Liquefaction of Barley Straw to Bio-Crude Oil: Effects of Reaction Temperature and Aqueous Phase Recirculation. Appl. Energy 2015, 137, 183-192. [CrossRef]

28. Kaur, R.; Gera, P.; Jha, M.K.; Bhaskar, T. Optimization of Process Parameters for Hydrothermal Conversion of Castor Residue. Sci. Total Environ. 2019, 686, 641-647. [CrossRef] [PubMed]

29. Bi, Z.; Zhang, J.; Peterson, E.; Zhu, Z.; Xia, C.; Liang, Y.; Wiltowski, T. Biocrude from Pretreated Sorghum Bagasse through Catalytic Hydrothermal Liquefaction. Fuel 2017, 188, 112-120. [CrossRef]

30. De Caprariis, B.; De Filippis, P.; Petrullo, A.; Scarsella, M. Hydrothermal Liquefaction of Biomass: Influence of Temperature and Biomass Composition on the Bio-Oil Production. Fuel 2017, 208, 618-625. [CrossRef]

31. De Caprariis, B.; Bavasso, I.; Bracciale, M.P.; Damizia, M.; De Filippis, P.; Scarsella, M. Enhanced Bio-Crude Yield and Quality by Reductive Hydrothermal Liquefaction of Oak Wood Biomass: Effect of Iron Addition. J. Anal. Appl. Pyrolysis 2019, 139, 123-130. [CrossRef]

32. Chan, Y.H.; Yusup, S.; Quitain, A.T.; Uemura, Y.; Sasaki, M. Bio-Oil Production from Oil Palm Biomass via Subcritical and Supercritical Hydrothermal Liquefaction. J. Supercrit. Fluids 2014, 95, 407-412. [CrossRef]

33. Wu, X.-F.; Zhou, Q.; Li, M.-F.; Li, S.-X.; Bian, J.; Peng, F. Conversion of Poplar into Bio-Oil via Subcritical Hydrothermal Liquefaction: Structure and Antioxidant Capacity. Bioresour. Technol. 2018, 270, 216-222. [CrossRef]

34. Malins, K. Production of Bio-Oil via Hydrothermal Liquefaction of Birch Sawdust. Energy Convers. Manag. 2017, 144, $243-251$. [CrossRef]

35. Jasiūnas, L.; Pedersen, T.H.; Toor, S.S.; Rosendahl, L.A. Biocrude Production via Supercritical Hydrothermal Co-Liquefaction of Spent Mushroom Compost and Aspen Wood Sawdust. Renew. Energy 2017, 111, 392-398. [CrossRef]

36. Durak, H.; Aysu, T. Structural Analysis of Bio-Oils from Subcritical and Supercritical Hydrothermal Liquefaction of Datura stramonium L. J. Supercrit. Fluids 2016, 108, 123-135. [CrossRef]

37. Tekin, K.; Akalin, M.K.; Karagöz, S. The Effects of Water Tolerant Lewis Acids on the Hydrothermal Liquefaction of Lignocellulosic Biomass. J. Energy Inst. 2016, 89, 627-635. [CrossRef]

38. Jindal, M.K.; Jha, M.K. Effect of Process Parameters on Hydrothermal Liquefaction of Waste Furniture Sawdust for Bio-Oil Production. RSC Adv. 2016, 6, 41772-41780. [CrossRef]

39. Liu, H.-M.; Wang, F.-Y.; Liu, Y.-L. Alkaline Pretreatment and Hydrothermal Liquefaction of Cypress for High Yield Bio-Oil Production. J. Anal. Appl. Pyrolysis 2014, 108, 136-142. [CrossRef]

40. Zhao, Y.-P.; Zhu, W.-W.; Wei, X.-Y.; Fan, X.; Cao, J.-P.; Dou, Y.-Q.; Zong, Z.-M.; Zhao, W. Synergic Effect of Methanol and Water on Pine Liquefaction. Bioresour. Technol. 2013, 142, 504-509. [CrossRef] [PubMed]

41. Sun, P.; Heng, M.; Sun, S.; Chen, J. Direct Liquefaction of Paulownia in Hot Compressed Water: Influence of Catalysts. Energy 2010, 35, 5421-5429. [CrossRef]

42. Mazaheri, H.; Lee, K.T.; Mohamed, A.R. Influence of Temperature on Liquid Products Yield of Oil Palm Shell via Subcritical Water Liquefaction in the Presence of Alkali Catalyst. Fuel Process. Technol. 2013, 110, 197-205. [CrossRef]

43. Tekin, K.; Karagöz, S.; Bektaş, S. Hydrothermal Liquefaction of Beech Wood Using a Natural Calcium Borate Mineral. J. Supercrit. Fluids 2012, 72, 134-139. [CrossRef]

44. Tekin, K.; Karagöz, S.; Bektaş, S. Effect of Sodium Perborate Monohydrate Concentrations on Product Distributions from the Hydrothermal Liquefaction of Scotch Pine Wood. Fuel Process. Technol. 2013, 110, 17-23. [CrossRef]

45. Yin, S.; Tan, Z. Hydrothermal Liquefaction of Cellulose to Bio-Oil under Acidic, Neutral and Alkaline Conditions. Appl. Energy 2012, 92, 234-239. [CrossRef]

46. Joksimovic, G.; Markovic, Z. Investigation of the Mechanism of Acidic Hydrolysis of Cellulose. Acta Agric. Serbica 2007, $12,51-57$.

47. Jin, F.; Wang, Y.; Zeng, X.; Shen, Z.; Yao, G. Water Under High Temperature and Pressure Conditions and Its Applications to Develop Green Technologies for Biomass Conversion. In Application of Hydrothermal Reactions to Biomass Conversion. Green Chemistry and Sustainable Technology; Jin, F., Ed.; Springer: Berlin/Heidelberg, Germany, 2014. [CrossRef]

48. Hirano, Y.; Miyataab, Y.; Taniguchia, M.; Funakoshia, N.; Yamazakia, Y.; Oginoa, C.; Kitaa, Y. Fe-Assisted Hydrothermal Liquefaction of Cellulose: Effects of Hydrogenation Catalyst Addition on Properties of Water-Soluble Fraction. J. Anal. Appl. Pyrolysis 2020, 145, 104719. [CrossRef]

49. Li, Q.; Liu, D.; Hou, X.; Wu, P.; Song, L.; Yan, Z. Hydro-Liquefaction of Microcrystalline Cellulose, Xylan and Industrial Lignin in Different Supercritical Solvents. Bioresour. Technol. 2016, 219, 281-288. [CrossRef] [PubMed]

50. Gao, Y.; Wang, X.-H.; Yang, H.-P.; Chen, H.-P. Characterization of Products from Hydrothermal Treatments of Cellulose. Energy 2012, 42, 457-465. [CrossRef]

51. Miyata, Y.; Sagata, K.; Hirose, M.; Yamazaki, Y.; Nishimura, A.; Okuda, N.; Arita, Y.; Hirano, Y.; Kita, Y. Fe-Assisted Hydrothermal Liquefaction of Lignocellulosic Biomass for Producing High-Grade Bio-Oil. ACS Sustain. Chem. Eng. 2017, 5, 3562-3569. [CrossRef]

52. Kang, S.; Li, X.; Fan, J.; Chang, J. Classified Separation of Lignin Hydrothermal Liquefied Products. Ind. Eng. Chem. Res. 2011, 50, 11288-11296. [CrossRef]

53. Arturi, K.R.; Strandgaard, M.; Nielsen, R.P.; Søgaard, E.G.; Maschietti, M. Hydrothermal Liquefaction of Lignin in Near-Critical Water in a New Batch Reactor: Influence of Phenol and Temperature. J. Supercrit. Fluids 2017, 123, 28-39. [CrossRef] 
54. Barbier, J.; Charon, N.; Dupassieux, N.; Loppinet-Serani, A.; Mahé, L.; Ponthus, J.; Courtiade, M.; Ducrozet, A.; Quoineaud, A.-A.; Cansell, F. Hydrothermal Conversion of Lignin Compounds. A Detailed Study of Fragmentation and Condensation Reaction Pathways. Biomass Bioenergy 2012, 46, 479-491. [CrossRef]

55. Kang, S.; Li, X.; Fan, J.; Chang, J. Hydrothermal Conversion of Lignin: A Review. Renew. Sustain. Energy Rev. 2013, 27, 546-558. [CrossRef]

56. Nguyen, T.D.H.; Maschietti, M.; Åmand, L.-E.; Vamling, L.; Olausson, L.; Andersson, S.-I.; Theliander, H. The Effect of Temperature on the Catalytic Conversion of Kraft Lignin Using Near-Critical Water. Bioresour. Technol. 2014, 170, 196-203. [CrossRef] [PubMed]

57. Wang, F.; Chang, Z.; Duan, P.; Yan, W.; Xu, Y.; Zhang, L.; Miao, J.; Fan, Y. Hydrothermal Liquefaction of Litsea cubeba Seed to Produce Bio-Oils. Bioresour. Technol. 2013, 149, 509-515. [CrossRef] [PubMed]

58. Brand, S.; Hardi, F.; Kim, J.; Suh, D.J. Effect of Heating Rate on Biomass Liquefaction: Differences Between Subcritical Water and Supercritical Ethanol. Energy 2014, 68, 420-427. [CrossRef]

59. Toor, S.S.; Rosendahl, L.; Nielsen, M.P.; Glasius, M.; Rudolf, A.; Iversen, S.B. Continuous Production of Bio-Oil by Catalytic Liquefaction from Wet distiller's Grain with Solubles (WDGS) from Bio-Ethanol Production. Biomass Bioenergy 2012, 36, 327-332. [CrossRef]

60. Mørup, A.J.; Christensen, P.R.; Aarup, D.F.; Dithmer, L.; Mamakhel, A.; Glasius, M.; Iversen, B.B. Hydrothermal Liquefaction of Dried Distillers Grains with Solubles: A Reaction Temperature Study. Energy Fuels 2012, 26, 5944-5953. [CrossRef]

61. Anastasakis, K.; Biller, P.; Madsen, R.B.; Glasius, M.; Johannsen, I. Continuous Hydrothermal Liquefaction of Biomass in a Novel Pilot Plant with Heat Recovery and Hydraulic Oscillation. Energies 2018, 11, 2695. [CrossRef]

62. Castello, D.; Pedersen, T.H.; Rosendahl, L.A. Continuous Hydrothermal Liquefaction of Biomass: A Critical Review. Energies 2018, 11, 3165. [CrossRef]

63. Tran, K.-Q. Fast Hydrothermal Liquefaction for Production of Chemicals and Biofuels from Wet Biomass-The Need to Develop a Plug-Flow Reactor. Bioresour. Technol. 2016, 213, 327-332. [CrossRef]

64. Sun, P.; Heng, M.; Sun, S.-H.; Chen, J. Analysis of Liquid and Solid Products from Liquefaction of Paulownia in Hot-Compressed Water. Energy Convers. Manag. 2011, 52, 924-933. [CrossRef]

65. Gan, J.; Yuan, W.; Johnson, L.; Wang, D.; Nelson, R.; Zhang, K. Hydrothermal Conversion of Big Bluestem for Bio-Oil Production: The Effect of Ecotype and Planting Location. Bioresour. Technol. 2012, 116, 413-420. [CrossRef] [PubMed]

66. Nazari, L.; Yuan, Z.; Souzanchi, S.; Ray, M.B.; Xu, C.C. Hydrothermal Liquefaction of Woody Biomass in Hot-Compressed Water: Catalyst Screening and Comprehensive Characterization of Bio-Crude Oils. Fuel 2015, 162, 74-83. [CrossRef]

67. Yan, Y.; Xu, J.; Li, T.; Ren, Z. Liquefaction of Sawdust for Liquid Fuel. Fuel Process. Technol. 1999, 60, 135-143. [CrossRef]

68. Lu, J.; Liu, Z.; Zhang, Y.; Savage, P.E. 110th Anniversary: Influence of Solvents on Biocrude from Hydrothermal Liquefaction of Soybean Oil, Soy Protein, Cellulose, Xylose, and Lignin, and Their Quinary Mixture. Ind. Eng. Chem. Res. 2019, 58, 13971-13976. [CrossRef]

69. Anouti, S.; Haarlemmer, G.; Déniel, M.; Roubaud, A. Analysis of Physicochemical Properties of Bio-Oil from Hydrothermal Liquefaction of Blackcurrant Pomace. Energy Fuels 2015, 30, 398-406. [CrossRef]

70. Karagöz, S.; Bhaskar, T.; Muto, A.; Sakata, Y.; Oshiki, T.; Kishimoto, T. Low-Temperature Catalytic Hydrothermal Treatment of Wood Biomass: Analysis of Liquid Products. Chem. Eng. J. 2005, 108, 127-137. [CrossRef]

71. Wang, B.; Huang, Y.; Zhang, J. Hydrothermal Liquefaction of Lignite, Wheat Straw and Plastic Waste in Sub-Critical Water for Oil: Product Distribution. J. Anal. Appl. Pyrolysis 2014, 110, 382-389. [CrossRef]

72. Zhang, B.; Von Keitz, M.; Valentas, K. Thermal Effects on Hydrothermal Biomass Liquefaction. Appl. Biochem. Biotechnol. 2008, 147, 143-150. [CrossRef]

73. Alba, L.G.; Torri, C.; Samori', C.; Van Der Spek, J.; Fabbri, D.; Kersten, S.R.A.; Brilman, D.W.F. Hydrothermal Treatment (HTT) of Microalgae: Evaluation of the Process as Conversion Method in an Algae Biorefinery Concept. Energy Fuels 2011, 26, 642-657. [CrossRef]

74. Jena, U.; Das, K.; Kastner, J. Effect of Operating Conditions of Thermochemical Liquefaction on Biocrude Production from Spirulina Platensis. Bioresour. Technol. 2011, 102, 6221-6229. [CrossRef]

75. Zhang, L.; Champagne, P.; Xu, C. Bio-Crude Production from Secondary pulp/Paper-Mill Sludge and Waste Newspaper via Co-Liquefaction in Hot-Compressed Water. Energy 2011, 36, 2142-2150. [CrossRef]

76. Akalın, M.K.; Tekin, K.; Karagöz, S. Hydrothermal Liquefaction of Cornelian Cherry Stones for Bio-Oil Production. Bioresour. Technol. 2012, 110, 682-687. [CrossRef]

77. Singh, R.; Chaudhary, K.; Biswas, B.; Balagurumurthy, B.; Bhaskar, T. Hydrothermal Liquefaction of Rice Straw: Effect of Reaction Environment. J. Supercrit. Fluids 2015, 104, 70-75. [CrossRef]

78. Isa, K.M.; Snape, C.; Uguna, C.N.; Meredith, W. High Conversions of Miscanthus Using Sub- and Supercritical Water above $400{ }^{\circ}$ C. J. Anal. Appl. Pyrolysis 2015, 113, 646-654. [CrossRef]

79. Yang, L.; Nazari, L.; Yuan, Z.; Corscadden, K.; Xu, C.; He, Q. Hydrothermal Liquefaction of Spent Coffee Grounds in Water Medium for Bio-Oil Production. Biomass Bioenergy 2016, 86, 191-198. [CrossRef]

80. Chang, C.-C.; Chen, C.-P.; Yang, C.-S.; Chen, Y.-H.; Huang, M.; Chang, C.-Y.; Shie, J.-L.; Yuan, M.-H.; Chen, Y.-H.; Ho, C.; et al. Conversion of Waste Bamboo Chopsticks to Bio-Oil via Catalytic Hydrothermal Liquefaction Using $\mathrm{K}_{2} \mathrm{CO}_{3}$. Sustain. Environ. Res. 2016, 26, 262-267. [CrossRef] 
81. Déniel, M.; Haarlemmer, G.; Roubaud, A.; Weiss-Hortala, E.; Fages, J. Optimisation of Bio-Oil Production by Hydrothermal Liquefaction of Agro-Industrial Residues: Blackcurrant Pomace (Ribes nigrum L.) As an Example. Biomass Bioenergy 2016, 95, 273-285. [CrossRef]

82. Yang, L.; He, Q.; Havard, P.; Corscadden, K.; Xu, C.; Wang, X. Co-Liquefaction of Spent Coffee Grounds and Lignocellulosic Feedstocks. Bioresour. Technol. 2017, 237, 108-121. [CrossRef] [PubMed]

83. Seshasayee, M.S.; Savage, P.E. Oil from Plastic via Hydrothermal Liquefaction: Production and Characterization. Appl. Energy 2020, 278. [CrossRef]

84. Durak, H.; Genel, S. Catalytic Hydrothermal Liquefaction of Lactuca Scariola with a Heterogeneous Catalyst: The Investigation of Temperature, Reaction Time and Synergistic Effect of Catalysts. Bioresour. Technol. 2020, 309, 123375. [CrossRef] [PubMed]

85. Evcil, T.; Tekin, K.; Ucar, S.; Karagoz, S. Hydrothermal Liquefaction of Olive Oil Residues. Sustain. Chem. Pharm. 2021, 22, 100476. [CrossRef]

86. Akhtar, J.; Amin, N.A.S. A Review on Process Conditions for Optimum Bio-Oil Yield in Hydrothermal Liquefaction of Biomass. Renew. Sustain. Energy Rev. 2011, 15, 1615-1624. [CrossRef]

87. Minowa, T.; Zhen, F.; Ogi, T. Cellulose Decomposition in Hot-Compressed Water with Alkali or Nickel Catalyst. J. Supercrit. Fluids 1998, 13, 253-259. [CrossRef]

88. Ogi, T.; Yokoyama, S.-Y.; Koguchi, K. Direct Liquefaction of Wood by Catalyst. Part 1. Effects of Pressure, Temperature, Holding Time and wood/catalyst/Water Ratio on Oil Yield. J. Jpn. Pet. Inst. 1985, 28, 239-245. [CrossRef]

89. Qu, Y.; Wei, X.; Zhong, C. Experimental Study on the Direct Liquefaction of Cunninghamia Lanceolata in Water. Energy 2003, 28, 597-606. [CrossRef]

90. Zhang, B.; von Keitz, M.; Valentas, K. Thermochemical Liquefaction of High-Diversity Grassland Perennials. J. Anal. Appl. Pyrolysis 2009, 84, 18-24. [CrossRef]

91. Demirbaş, A.; Balat, M.; Bozbas, K. Direct and Catalytic Liquefaction of Wood Species in Aqueous Solution. Energy Sources 2005, 27, 271-277. [CrossRef]

92. Zheng, J.-L.; Zhu, M.-Q.; Wu, H.-T. Alkaline Hydrothermal Liquefaction of Swine Carcasses to Bio-Oil. Waste Manag. 2015, 43, 230-238. [CrossRef] [PubMed]

93. Lee, J.H.; Hwang, H.; Moon, J.; Choi, J.W. Characterization of Hydrothermal Liquefaction Products from Coconut Shell in the Presence of Selected Transition Metal Chlorides. J. Anal. Appl. Pyrolysis 2016, 122, 415-421. [CrossRef]

94. Khampuang, K.; Boreriboon, N.; Prasassarakich, P. Alkali Catalyzed Liquefaction of Corncob in Supercritical ethanol-water. Biomass Bioenergy 2015, 83, 460-466. [CrossRef]

95. Yin, S.; Dolan, R.; Harris, M.; Tan, Z. Subcritical Hydrothermal Liquefaction of Cattle Manure to Bio-Oil: Effects of Conversion Parameters on Bio-Oil Yield and Characterization of Bio-Oil. Bioresour. Technol. 2010, 101, 3657-3664. [CrossRef]

96. Xu, C.; Lancaster, J. Conversion of Secondary pulp/Paper Sludge Powder to Liquid Oil Products for Energy Recovery by Direct Liquefaction in Hot-Compressed Water. Water Res. 2008, 42, 1571-1582. [CrossRef]

97. Yang, Y.; Gilbert, A.; Xu, C. Production of Bio-Crude from Forestry Waste by Hydro-Liquefaction in Sub-/Super-Critical Methanol. AIChE J. 2009, 55, 807-819. [CrossRef]

98. Brand, S.; Susanti, R.F.; Kim, S.K.; Lee, H.-S.; Kim, J.; Sang, B.-I. Supercritical Ethanol as an Enhanced Medium for Lignocellulosic Biomass Liquefaction: Influence of Physical Process Parameters. Energy 2013, 59, 173-182. [CrossRef]

99. Kabyemela, B.M.; Takigawa, M.; Adschiri, T.; Malaluan, R.M.; Arai, K. Mechanism and Kinetics of Cellobiose Decomposition in Sub- and Supercritical Water. Ind. Eng. Chem. Res. 1998, 37, 357-361. [CrossRef]

100. Cantero, D.A.; Tapia, Á.S.; Bermejo, M.D.; Cocero, M.J. Pressure and Temperature Effect on Cellulose Hydrolysis in Pressurized Water. Chem. Eng. J. 2015, 276, 145-154. [CrossRef]

101. Kruse, A.; Gawlik, A. Biomass Conversion in Water at $330-410{ }^{\circ} \mathrm{C}$ and $30-50 \mathrm{MPa}$. Identification of Key Compounds for Indicating Different Chemical Reaction Pathways. Ind. Eng. Chem. Res. 2003, 42, 267-279. [CrossRef]

102. Zhang, J.; Chen, W.-T.; Zhang, P.; Luo, Z.; Zhang, Y. Hydrothermal Liquefaction of Chlorella Pyrenoidosa in Sub- and Supercritical Ethanol with Heterogeneous Catalysts. Bioresour. Technol. 2013, 133, 389-397. [CrossRef] [PubMed]

103. Yim, S.C.; Quitain, A.T.; Yusup, S.; Sasaki, M.; Uemura, Y.; Kida, T. Metal Oxide-Catalyzed Hydrothermal Liquefaction of Malaysian Oil Palm Biomass to Bio-Oil under Supercritical Condition. J. Supercrit. Fluids 2017, 120, 384-394. [CrossRef]

104. Tran, K.-Q.; Klemsdal, A.J.; Zhang, W.; Sandquist, J.; Wang, L.; Skreiberg, Ø. Fast Hydrothermal Liquefaction of Native and Torrefied Wood. Energy Procedia 2017, 105, 218-223. [CrossRef]

105. Bach, Q.-V.; Sillero, M.V.; Tran, Q.; Skjermo, J. Fast Hydrothermal Liquefaction of a Norwegian Macro-Alga: Screening Tests. Algal Res. 2014, 6, 271-276. [CrossRef]

106. Biller, P.; Riley, R.; Ross, A. Catalytic Hydrothermal Processing of Microalgae: Decomposition and Upgrading of Lipids. Bioresour. Technol. 2011, 102, 4841-4848. [CrossRef]

107. Biller, P.; Ross, A. Potential Yields and Properties of Oil from the Hydrothermal Liquefaction of Microalgae with Different Biochemical Content. Bioresour. Technol. 2011, 102, 215-225. [CrossRef]

108. Akhtar, J.; Kuang, S.K.; Amin, N.S. Liquefaction of Empty Palm Fruit Bunch (EPFB) in Alkaline Hot Compressed Water. Renew. Energy 2010, 35, 1220-1227. [CrossRef]

109. Karagöz, S.; Bhaskar, T.; Muto, A.; Sakata, Y. Catalytic Hydrothermal Treatment of Pine Wood Biomass: Effect of RbOH and $\mathrm{CsOH}$ on Product Distribution. J. Chem. Technol. Biotechnol. 2005, 80, 1097-1102. [CrossRef] 
110. Karagöz, S.; Bhaskar, T.; Muto, A.; Sakata, Y. Effect of Rb and Cs Carbonates for Production of Phenols from Liquefaction of Wood Biomass. Fuel 2004, 83, 2293-2299. [CrossRef]

111. Tekin, K.; Karagöz, S. T-BuOK Catalyzed Bio-Oil Production from Woody Biomass under Sub-Critical Water Conditions. Environ. Chem. Lett. 2013, 11, 25-31. [CrossRef]

112. Chen, Y.; Mu, R.; Yang, M.; Fang, L.; Wu, Y.; Wu, K.; Liu, Y.; Gong, J. Catalytic Hydrothermal Liquefaction for Bio-Oil Production over CNTs Supported Metal Catalysts. Chem. Eng. Sci. 2017, 161, 299-307. [CrossRef]

113. Basar, I.A.; Liu, H.; Carrere, H.; Trably, E.; Eskicioglu, C. A Review on Key Design and Operational Parameters to Optimize and Develop Hydrothermal Liquefaction of Biomass for Biorefinery Applications. Green Chem. 2021, 23, 1404-1446. [CrossRef]

114. Chen, Y.; Cao, X.; Zhu, S.; Tian, F.; Xu, Y.; Zhu, C.; Dong, L. Synergistic Hydrothermal Liquefaction of Wheat Stalk With Homogeneous and Heterogeneous Catalyst at Low Temperature. Bioresour. Technol. 2019, 278, 92-98. [CrossRef] [PubMed]

115. Aysu, T.; Durak, H. Bio-Oil Production via Catalytic Supercritical Liquefaction of Syrian Mesquite (Prosopis farcta). J. Supercrit. Fluids 2016, 109, 26-34. [CrossRef]

116. Durak, H.; Aysu, T. Effects of Catalysts and Solvents on Liquefaction of Onopordum Heteracanthum for Production of Bio-Oils. Bioresour. Technol. 2014, 166, 309-317. [CrossRef]

117. Karagoz, S.; Bhaskar, T.; Muto, A.; Sakata, Y. Hydrothermal Upgrading of Biomass: Effect of KCO Concentration and biomass/Water Ratio on Products Distribution. Bioresour. Technol. 2006, 97, 90-98. [CrossRef] [PubMed]

118. Miyata, Y.; Yamazaki, Y.; Hirano, Y.; Kita, Y. Quantitative Analysis of the Aqueous Fraction from the Fe-Assisted Hydrothermal Liquefaction of Oil Palm Empty Fruit Bunches. J. Anal. Appl. Pyrolysis 2018, 132, 72-81. [CrossRef]

119. Zhou, C.; Zhu, X.; Qian, F.; Shen, W.; Xu, H.; Zhang, S.; Chen, J. Catalytic Hydrothermal Liquefaction of Rice Straw in water/Ethanol Mixtures for High Yields of Monomeric Phenols Using Reductive CuZnAl Catalyst. Fuel Process. Technol. 2016, 154, 1-6. [CrossRef]

120. Liu, D.; Li, Q.; Zhao, A.; Song, L.; Wu, P.; Yan, Z. Hydro-Liquefaction of Sawdust and Its Three Components in Supercritical Ethanol With [BMIM]Cl/ $\mathrm{NiCl}_{2}$ Catalyst. Chem. Eng. J. 2015, 279, 921-928. [CrossRef]

121. Ding, Y.-J.; Zhao, C.-X.; Liu, Z.-C. Catalytic Hydrothermal Liquefaction of Rice Straw for Production of Monomers Phenol over Metal Supported Mesoporous Catalyst. Bioresour. Technol. 2019, 294, 122097. [CrossRef]

122. Lee, J.H.; Hwang, H.; Choi, J.W. Effects of Transition Metals on Hydrothermal Liquefaction of Empty Fruit Bunches (EFB) for Conversion to Biofuel and Valuable Chemicals. Energy 2018, 162, 1-9. [CrossRef]

123. Cheng, S.; Wei, L.; Rabnawaz, M. Catalytic Liquefaction of Pine Sawdust and in-Situ Hydrogenation of Bio-Crude over Bifunctional Co-Zn/HZSM-5 Catalysts. Fuel 2018, 223, 252-260. [CrossRef]

124. Alper, K.; Tekin, K.; Karagoz, S. Hydrothermal Liquefaction of Lignocellulosic Biomass Using Potassium Fluoride-Doped Alumina. Energy Fuels 2019, 33, 3248-3256. [CrossRef]

125. Bian, J.; Zhang, Q.; Zhang, P.; Feng, L.; Li, C. Supported $\mathrm{Fe}_{2} \mathrm{O}_{3}$ Nanoparticles for Catalytic Upgrading of Microalgae Hydrothermal Liquefaction Derived Bio-Oil. Catal. Today 2017, 293-294, 159-166. [CrossRef]

126. Bhalkikar, A.; Gernhart, Z.C.; Cheung, C.L. Recyclable Magnetite Nanoparticle Catalyst for One-Pot Conversion of Cellobiose to 5-Hydroxymethylfurfural in Water. J. Nanomater. 2015, 2015, 1-8. [CrossRef]

127. Cheng, S.; D'Cruz, I.; Wang, M.; Leitch, M.; Xu, C. Highly Efficient Liquefaction of Woody Biomass in Hot-Compressed Alcohol-Water Co-solvents. Energy Fuels 2010, 24, 4659-4667. [CrossRef]

128. Chumpoo, J.; Prasassarakich, P. Bio-Oil from Hydro-Liquefaction of Bagasse in Supercritical Ethanol. Energy Fuels 2010, 24, 2071-2077. [CrossRef]

129. Chen, Y.; Wu, Y.; Zhang, P.; Hua, D.; Yang, M.; Li, C.; Chen, Z.; Liu, J. Direct Liquefaction of Dunaliella Tertiolecta for Bio-Oil in sub/Supercritical ethanol-water. Bioresour. Technol. 2012, 124, 190-198. [CrossRef] [PubMed]

130. Liu, Y.; Yuan, X.-Z.; Huang, H.-J.; Wang, X.-L.; Wang, H.; Zeng, G.-M. Thermochemical Liquefaction of Rice Husk for Bio-Oil Production in Mixed Solvent (ethanol-water). Fuel Process. Technol. 2013, 112, 93-99. [CrossRef]

131. Zhu, W.-W.; Zong, Z.-M.; Yan, H.-L.; Zhao, Y.-P.; Lu, Y.; Wei, X.-Y.; Zhang, D. Cornstalk Liquefaction in methanol/Water Mixed Solvents. Fuel Process. Technol. 2014, 117, 1-7. [CrossRef]

132. Patil, P.T.; Armbruster, U.; Martin, A. Hydrothermal Liquefaction of Wheat Straw in Hot Compressed Water and Subcritical water-alcohol Mixtures. J. Supercrit. Fluids 2014, 93, 121-129. [CrossRef]

133. Kosinkova, J.; Ramirez, J.A.; Nguyen, J.; Ristovski, Z.; Brown, R.J.; Lin, C.S.K.; Rainey, T.J. Hydrothermal Liquefaction of Bagasse Using Ethanol and Black Liquor as Solvents. Biofuels Bioprod. Biorefining 2015, 9, 630-638. [CrossRef]

134. Yan, H.-L.; Zong, Z.-M.; Zhu, W.-W.; Li, Z.-K.; Wang, Y.-G.; Wei, Z.; Li, Y.; Wei, X.-Y. Poplar Liquefaction in Water/Methanol Cosolvents. Energy Fuels 2015, 29, 3104-3110. [CrossRef]

135. He, Y.; Liang, X.; Jazrawi, C.; Montoya, A.; Yuen, A.; Cole, A.J.; Neveux, N.; Paul, N.; de Nys, R.; Maschmeyer, T.; et al. Continuous Hydrothermal Liquefaction of Macroalgae in the Presence of Organic Co-Solvents. Algal Res. 2016, 17, 185-195. [CrossRef]

136. Feng, S.; Wei, R.; Leitch, M.; Xu, C.C. Comparative Study on Lignocellulose Liquefaction in Water, Ethanol, and water/Ethanol Mixture: Roles of Ethanol and Water. Energy 2018, 155, 234-241. [CrossRef]

137. Pan, Z.-Q.; Huang, H.-J.; Zhou, C.-F.; Xiao, X.-F.; He, X.-W.; Lai, F.-Y.; Xiong, J.-B. Highly Efficient Conversion of Camphor Tree Sawdust into Bio-Oil and Biochar Products by Liquefaction in Ethanol-Water Cosolvent. J. Anal. Appl. Pyrolysis 2018, 136, 186-198. [CrossRef] 
138. Lai, F.-Y.; Chang, Y.-C.; Huang, H.-J.; Wu, G.-Q.; Xiong, J.-B.; Pan, Z.-Q.; Zhou, C.-F. Liquefaction of Sewage Sludge in EthanolWater Mixed Solvents for Bio-Oil and Biochar Products. Energy 2018, 148, 629-641. [CrossRef]

139. Li, R.; Ma, Z.; Yang, T.; Li, B.; Wei, L.; Sun, Y. Sub-supercritical Liquefaction of Municipal Wet Sewage Sludge to Produce Bio-Oil: Effect of Different organic-water Mixed Solvents. J. Supercrit. Fluids 2018, 138, 115-123. [CrossRef]

140. Yuan, C.; Wang, S.; Qian, L.; Barati, B.; Gong, X.; Abomohra, A.E.-F.; Wang, X.; Esakkimuthu, S.; Hu, Y.; Liu, L. Effect of Cosolvent and Addition of Catalyst (HZSM-5) on Hydrothermal Liquefaction of Macroalgae. Int. J. Energy Res. 2019, 43, 8841-8851. [CrossRef]

141. Hu, Y.; Gu, Z.; Li, W.; Xu, C. Alkali-Catalyzed Liquefaction of Pinewood Sawdust in ethanol/Water Co-Solvents. Biomass Bioenergy 2020, 134, 105485. [CrossRef]

142. Shie, J.-L.; Yang, W.-S.; Liau, Y.-R.; Liau, T.-H.; Yang, H.-R. Subcritical Hydrothermal Co-Liquefaction of Process Rejects at a Wastepaper-Based Paper Mill with Waste Soybean Oil. Energies 2021, 14, 2442. [CrossRef]

143. Marcus, Y. Extraction by Subcritical and Supercritical Water, Methanol, Ethanol and Their Mixtures. Separations 2018, 5, 4. [CrossRef]

144. Kus, N.S. Organic Reactions in Subcritical and Supercritical Water. Tetrahedron 2012, 68, 949-958. [CrossRef]

145. Ogi, T.; Yokoyama, S.-Y. Liquid Fuel Production from Woody Biomass by Direct Liquefaction. J. Jpn. Pet. Inst. 1993, 36, 73-84. [CrossRef]

146. Yuan, X.; Li, H.; Zeng, G.; Tong, J.; Xie, W. Sub- and Supercritical Liquefaction of Rice Straw in the Presence of ethanol-water and 2-propanol-water Mixture. Energy 2007, 32, 2081-2088. [CrossRef]

147. Li, H.; Yuan, X.; Zeng, G.; Tong, J.; Yan, Y.; Cao, H.; Wang, L.; Cheng, M.; Zhang, J.; Yang, D. Liquefaction of Rice Straw in Suband Supercritical 1,4-dioxane-water Mixture. Fuel Process. Technol. 2009, 90, 657-663. [CrossRef]

148. Cao, L.; Zhang, C.; Hao, S.; Luo, G.; Zhang, S.; Chen, J. Effect of Glycerol As Co-Solvent on Yields of Bio-Oil from Rice Straw through Hydrothermal Liquefaction. Bioresour. Technol. 2016, 220, 471-478. [CrossRef]

149. Tomoko, O.; Minowa, T.; Dote, Y.; Yokoyama, S.-Y. Characterization of Oil Produced by the Direct Liquefaction of Japanese Oak in an Aqueous 2-Propanol Solvent System. Biomass Bioenergy 1994, 7, 193-199.

150. Minami, E.; Saka, S. Decomposition Behavior of Woody Biomass in Water-Added Supercritical Methanol. J. Wood Sci. 2005, 51, 395-400. [CrossRef]

151. Savage, P. Organic Chemical Reactions in Supercritical Water. Chem. Rev. 1999, 99, 603-622. [CrossRef] [PubMed]

152. Balogh, D.; Curvelo, A.; De Groote, R. Solvent Effects on Organosolv Lignin from Pinus Caribaea Hondurensis. Holzforschung 1992, 46, 343-348. [CrossRef]

153. Pasquini, D.; Pimenta, M.T.B.; Ferreira, L.H.; Curvelo, A.A.D.S. Extraction of Lignin from Sugar Cane Bagasse and Pinus Taeda Wood Chips Using ethanol-water Mixtures and Carbon Dioxide at High Pressures. J. Supercrit. Fluids 2005, 36, 31-39. [CrossRef]

154. Valdez, P.J.; Dickinson, J.G.; Savage, P.E. Characterization of Product Fractions from Hydrothermal Liquefaction of Naninochloropsis Sp. And the Influence of Solvents. Energy Fuels 2011, 25, 3235-3243. [CrossRef]

155. Yan, W.-H.; Duan, P.-G.; Wang, F.; Xu, Y.-P. Composition of the Bio-Oil from the Hydrothermal Liquefaction of Duckweed and the Influence of the Extraction Solvents. Fuel 2016, 185, 229-235. [CrossRef]

156. Yang, X.; Lyu, H.; Chen, K.; Zhu, X.; Zhang, S.; Chen, J. Selective Extraction of Bio-Oil from Hydrothermal Liquefaction of Salix psammophila by Organic Solvents With Different Polarities through Multistep Extraction Separation. BioResources 2014, 9 , 5219-5233. [CrossRef]

157. Yang, J.; He, Q.; Yang, L. A Review on Hydrothermal Co-Liquefaction of Biomass. Appl. Energy 2019, 250, 926-945. [CrossRef]

158. Jiang, J.; Savage, P.E. Influence of Process Conditions and Interventions on Metals Content in Biocrude from Hydrothermal Liquefaction of Microalgae. Algal Res. 2017, 26, 131-134. [CrossRef]

159. Xu, D.; Savage, P. Characterization of Biocrudes Recovered with and Without Solvent After Hydrothermal Liquefaction of Algae. Algal Res. 2014, 6, 1-7. [CrossRef]

160. Watson, J.; Lu, J.; de Souza, R.; Si, B.; Zhang, Y.; Liu, Z. Effects of the Extraction Solvents in Hydrothermal Liquefaction Processes: Biocrude Oil Quality and Energy Conversion Efficiency. Energy 2019, 167, 189-197. [CrossRef]

161. Karagöz, S.; Bhaskar, T.; Muto, A.; Sakata, Y.; Uddin, A. Low-Temperature Hydrothermal Treatment of Biomass: Effect of Reaction Parameters on Products and Boiling Point Distributions. Energy Fuels 2004, 18, 234-241. [CrossRef]

162. Zhu, Y.; Biddy, M.J.; Jones, S.B.; Elliott, D.; Schmidt, A.J. Techno-Economic Analysis of Liquid Fuel Production from Woody Biomass via Hydrothermal Liquefaction (HTL) and Upgrading. Appl. Energy 2014, 129, 384-394. [CrossRef]

163. Taghipour, A.; Ramirez, J.A.; Brown, R.J.; Rainey, T.J. A Review of Fractional Distillation to Improve Hydrothermal Liquefaction Biocrude Characteristics; Future Outlook and Prospects. Renew. Sustain. Energy Rev. 2019, 115, 109355. [CrossRef]

164. Pedersen, T.; Jensen, C.; Sandström, L.; Rosendahl, L. Full Characterization of Compounds Obtained from Fractional Distillation and Upgrading of a HTL Biocrude. Appl. Energy 2017, 202, 408-419. [CrossRef]

165. Tzanetis, K.F.; Posada, J.A.; Ramirez, A. Analysis of Biomass Hydrothermal Liquefaction and Biocrude-Oil Upgrading for Renewable Jet Fuel Production: The Impact of Reaction Conditions on Production Costs and GHG Emissions Performance. Renew. Energy 2017, 113, 1388-1398. [CrossRef]

166. Yang, S.; Yuan, T.-Q.; Li, M.-F.; Sun, R.-C. Hydrothermal Degradation of Lignin: Products Analysis for Phenol Formaldehyde Adhesive Synthesis. Int. J. Biol. Macromol. 2015, 72, 54-62. [CrossRef] [PubMed] 
167. Jiang, W.; Kumar, A.; Adamopoulos, S. Liquefaction of Lignocellulosic Materials and Its Applications in Wood adhesives-A Review. Ind. Crop. Prod. 2018, 124, 325-342. [CrossRef]

168. Wang, M.; Xu, C.C.; Leitch, M. Liquefaction of Cornstalk in Hot-Compressed phenol-water Medium to Phenolic Feedstock for the Synthesis of phenol-formaldehyde Resin. Bioresour. Technol. 2009, 100, 2305-2307. [CrossRef] [PubMed]

169. Feng, S.; Yuan, Z.; Leitch, M.; Shui, H.; Xu, C.C. Effects of Bark Extraction before Liquefaction and Liquid Oil Fractionation After Liquefaction on Bark-Based Phenol Formaldehyde Resoles. Ind. Crops Prod. 2016, 84, 330-336. [CrossRef]

170. Panisko, E.; Wietsma, T.; Lemmon, T.; Albrecht, K.; Howe, D. Characterization of the Aqueous Fractions from Hydrotreatment and Hydrothermal Liquefaction of Lignocellulosic Feedstocks. Biomass Bioenergy 2015, 74, 162-171. [CrossRef]

171. Biller, P.; Madsen, R.B.; Klemmer, M.; Becker, J.; Iversen, B.; Glasius, M. Effect of Hydrothermal Liquefaction Aqueous Phase Recycling on Bio-Crude Yields and Composition. Bioresour. Technol. 2016, 220, 190-199. [CrossRef]

172. Miyata, Y.; Sagata, K.; Yamazaki, Y.; Teramura, H.; Hirano, Y.; Ogino, C.; Kita, Y. Mechanism of the Fe-Assisted Hydrothermal Liquefaction of Lignocellulosic Biomass. Ind. Eng. Chem. Res. 2018, 57, 14870-14877. [CrossRef]

173. Elliott, D.; Hart, T.; Schmidt, A.J.; Neuenschwander, G.G.; Rotness, L.J.; Olarte, M.V.; Zacher, A.H.; Albrecht, K.O.; Hallen, R.T.; Holladay, J.E. Process Development for Hydrothermal Liquefaction of Algae Feedstocks in a Continuous-Flow Reactor. Algal Res. 2013, 2, 445-454. [CrossRef]

174. Xu, D.; Liu, L.; Wei, N.; Guo, Y.; Wang, S.; Wu, Z.; Duan, P. Catalytic Supercritical Water Gasification of Aqueous Phase Directly Derived from Microalgae Hydrothermal Liquefaction. Int. J. Hydrogen Energy 2019, 44, 26181-26192. [CrossRef]

175. Demirbaş, A. Effect of Lignin Content on Aqueous Liquefaction Products of Biomass. Energy Convers. Manag. 2000, 41, 1601-1607. [CrossRef]

176. Liu, Z.; Quek, A.; Hoekman, S.K.; Balasubramanian, R. Production of Solid Biochar Fuel from Waste Biomass by Hydrothermal Carbonization. Fuel 2013, 103, 943-949. [CrossRef]

177. Hoekman, S.K.; Broch, A.; Robbins, C. Hydrothermal carbonization (HTC) of lignocellulosic biomass. Energy Fuels 2011, 25, 1802-1810. [CrossRef]

178. Liu, Z.; Zhang, F.-S. Removal of Lead from Water Using Biochars Prepared from Hydrothermal Liquefaction of Biomass. J. Hazard. Mater. 2009, 167, 933-939. [CrossRef] [PubMed]

179. Bargmann, I.; Rillig, M.; Kruse, A.; Greef, J.-M.; Kücke, M. Effects of Hydrochar Application on the Dynamics of Soluble Nitrogen in Soils and on Plant Availability. J. Plant Nutr. Soil Sci. 2014, 177, 48-58. [CrossRef]

180. Baronti, S.; Alberti, G.; Camin, F.; Criscuoli, I.; Genesio, L.; Mass, R.; Vaccari, F.P.; Ziller, L.; Miglietta, F. Hydrochar Enhances Growth of Poplar for Bioenergy While Marginally Contributing to Direct Soil Carbon Sequestration. GCB Bioenergy 2017, 9 , 1618-1626. [CrossRef]

181. Kalderis, D.; Papameletiou, G.; Kayan, B. Assessment of Orange Peel Hydrochar as a Soil Amendment: Impact on Clay Soil Physical Properties and Potential Phytotoxicity. Waste Biomass Valorization 2019, 10, 3471-3484. [CrossRef]

182. Ding, L.; Wang, Z.; Li, Y.; Du, Y.; Liu, H.; Guo, Y. A Novel Hydrochar and Nickel Composite for the Electrochemical Supercapacitor Electrode Material. Mater. Lett. 2012, 74, 111-114. [CrossRef]

183. Ding, L.; Zou, B.; Li, Y.; Liu, H.; Wang, Z.; Zhao, C.; Su, Y.; Guo, Y. The Production of Hydrochar-Based Hierarchical Porous Carbons for Use as Electrochemical Supercapacitor Electrode Materials. Colloids Surfaces A Physicochem. Eng. Asp. 2013, 423, 104-111. [CrossRef]

184. Reza, M.T.; Lynam, J.; Uddin, M.H.; Coronella, C.J. Hydrothermal Carbonization: Fate of Inorganics. Biomass Bioenergy 2013, 49, 86-94. [CrossRef]

185. Smith, A.; Singh, S.; Ross, A.B. Fate of Inorganic Material During Hydrothermal Carbonisation of Biomass: Influence of Feedstock on Combustion Behaviour of Hydrochar. Fuel 2016, 169, 135-145. [CrossRef]

186. Neveux, N.; Yuen, A.; Jazrawi, C.; Magnusson, M.; Haynes, B.; Masters, A.; Montoya, A.; Paul, N.; Maschmeyer, T.; de Nys, R. Biocrude Yield and Productivity from the Hydrothermal Liquefaction of Marine and Freshwater Green Macroalgae. Bioresour. Technol. 2014, 155, 334-341. [CrossRef] 